Um estudo sobre o uso de WebQuests para revisar conteúdos matemáticos

Bruno de Moraes Turci 

Assinatura:

\title{
Um estudo sobre o uso de WebQuests para revisar conteúdos matemáticos
}

\author{
Bruno de Moraes Turci
}

Orientadora: Profa. Dra. Miriam Cardoso Utsumi

\begin{abstract}
Dissertação apresentada ao Instituto de Ciências Matemáticas e de Computação - ICMC-USP, como parte dos requisitos para obtenção do título de Mestre - Programa de Mestrado Profissional em Matemática VERSÃO REVISADA.
\end{abstract}


Ficha catalográfica elaborada pela Biblioteca Prof. Achille Bassi e Seção Técnica de Informática, ICMC/USP, com os dados fornecidos pelo(a) autor(a)

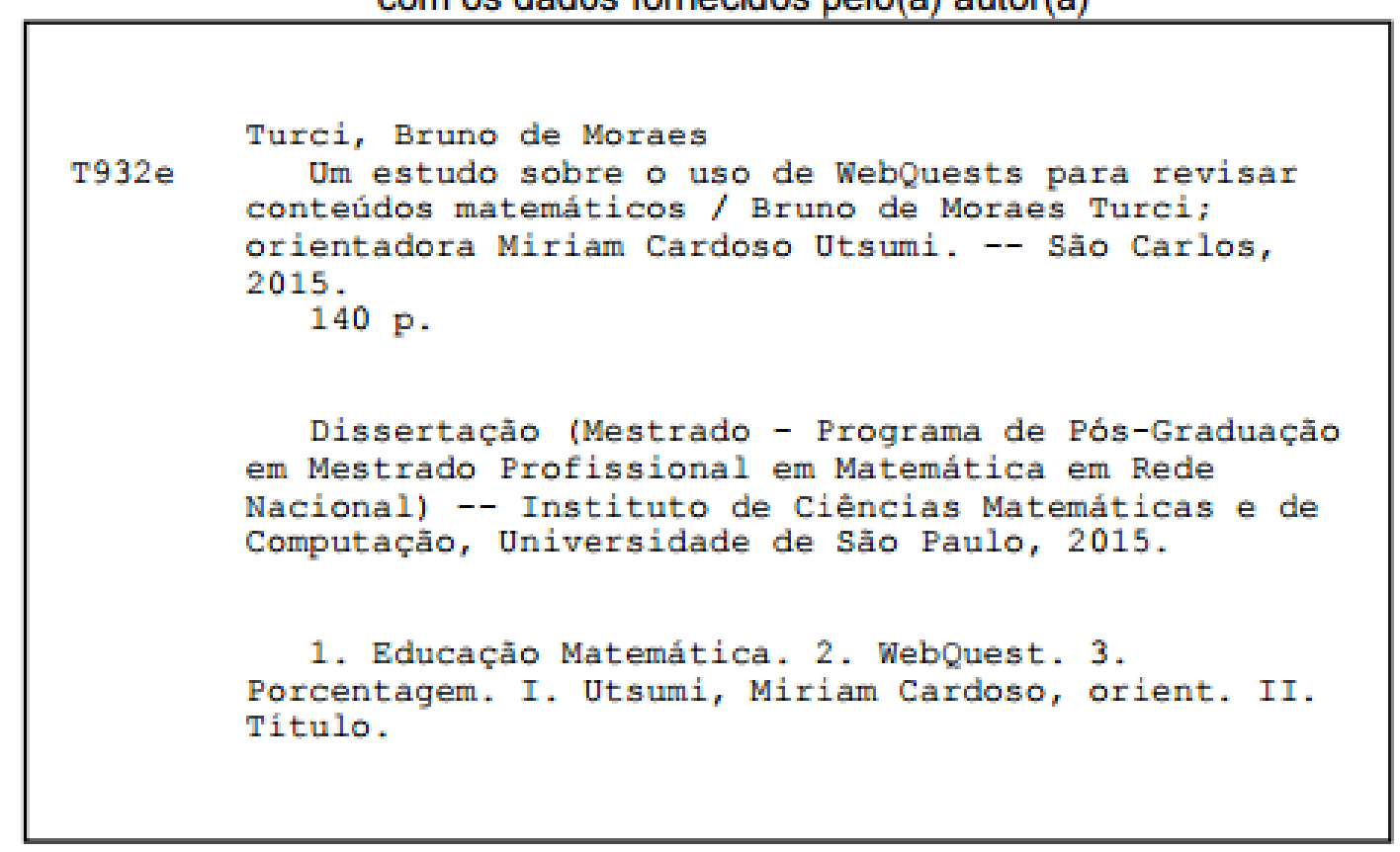


Dedico esta dissertação aos meus avós e aos meus pais. Bases de minha formação. 



\section{Agradecimentos}

Em primeiro lugar agradeço ao Piu e a Nega, meus pais, que me proporcionaram as oportunidades e as condições necessárias para que pudesse realizar meus estudos. Aos meus familiares professores, influências diretas em minha vocação. $E$ a minha Bixetinha que cuidou muito bem de mim enquanto eu escrevia as páginas que seguem.

Agradeço aos professores e aos colegas professores que encontrei durante o mestrado, cada um a sua maneira contribuiu para que eu completasse essa jornada.

Aos moradores e agregados da República Afeganistão, em especial Turtle e Peter, pelos anos de companheirismo, Chiba e Kamaras, pelos bate- papos científicos e meu amigo de longa data José Bubina, pelos papos filosóficos.

Agradeço também aos meus amigos Helton e Tia Li que por vezes estiveram comigo durante o trabalho duro. A amizade de vocês me é extremamente valiosa.

Por fim, agradeço a minha orientadora Profa. Dra. Miriam Cardoso Utsumi por ter acreditado em mim em vários momentos da minha formação. Obrigado professora! 



\section{Lista de Figuras}

Figura 1 - Proporção de domicílios com computador (2008 - 2012)................ 21

Figura 2 - Proporção de domicílios com acesso à Internet, por área (2008 -

2012) Percentual sobre o total de domicílios.

Figura 3 - Proporção de empresas que utilizaram computadores e Internet nos últimos 12 meses (2007-2012). Percentual sobre o total de empresas............ 22

Figura 4 - Exemplo de WebQuest - Fonte própria. ...................................... 37

Figura 5 - Número de capítulos sobre Porcentagem por coleção e Ano escolar -

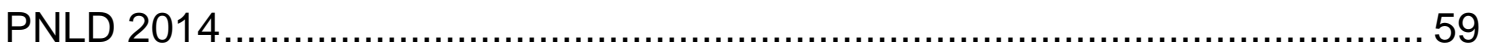

Figura 6 - Espiral de ciclos auto-reflexivos na pesquisa-ação......................... 65

Figura 7- Croqui do laboratório de informática - Fonte própria........................70

Figura 8- Introdução WQ BMW vermelho -

https://sites.google.com/site/bmwvermelho/home .................................... 88

Figura 9- Tarefas WQ BMW vermelho -

https://sites.google.com/site/bmwvermelho/tarefas .................................. 89

Figura 10- Processo WQ BMW vermelho -

https://sites.google.com/site/bmwvermelho/processo ............................... 90

Figura 11 - Avaliação WQ BMW vermelho -

https://sites.google.com/site/bmwvermelho/avaliacao ................................. 92

Figura 12 - Conclusões WQ BMW vermelho -

https://sites.google.com/site/bmwvermelho/conclusoes

Figura 13 - Extrato do protocolo dos alunos A16a2013 e A17a2013 na Tarefa 1.

Figura 14 - Extrato do protocolo dos alunos A8a2013 e A9a2013 na Tarefa 2.99

Figura 15 - Histograma das notas antes da aplicação da WQ ...................... 113

Figura 16 - Histograma das notas depois da aplicação da WQ.................... 114

Figura 17 - Questão 1 da lista de exercícios da tarefa 4 ........................... 116

Figura 18 - Extrato dos protocolos do aluno A11b2013, exercício 1 da Tarefa 4,

antes e depois da WQ ................................................................. 117

Figura 19 - Extrato do protocolo do aluno A4a2013, exercício 1 da Tarefa 4 em

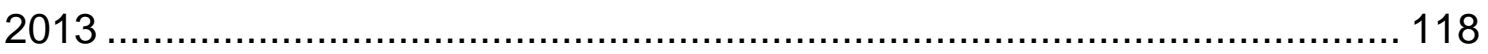

Figura 20 - Questão 2 da lista de exercícios da Tarefa 4 ............................. 120

Figura 21 - Extrato do protocolo dos alunos A7a2013 e A1a2013. ............... 120

Figura 22 - Extrato do protocolo do aluno A16b2013 antes. ......................... 121

Figura 23 - Questão 3 da lista de exercícios da Tarefa $4 \ldots \ldots \ldots \ldots \ldots \ldots \ldots \ldots \ldots . . . . . . . . . . . . .122$

Figura 24 - Extrato do protocolo da aluna A14a2013................................ 123

Figura 25 - Questão 4 da lista de exercícios da tarefa 4 ............................ 124

Figura 26 - Extrato dos protocolos dos alunos A18a2013 e A15b2013......... 125

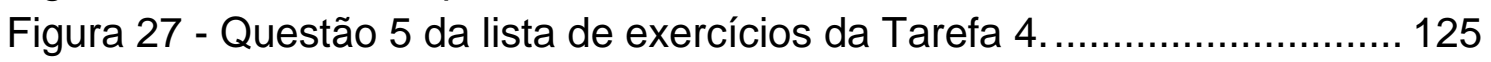

Figura 28 - Extrato do protocolo do aluno A1a2013 ..................................... 126

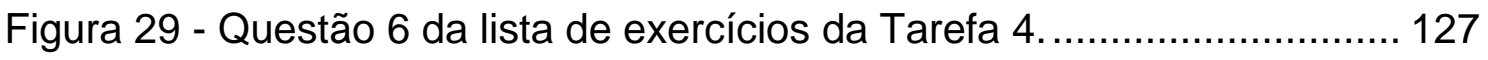

Figura 30 - Extrato do protocolo da aluna A1a2013 ................................. 127 



\section{Lista de Tabelas}

Tabela 1- Distribuição das notas dos alunos na Tarefa 1 ........................... 96

Tabela 2- Distribuição das notas dos alunos na Tarefa 2 ............................ 98

Tabela 3 - Distribuição das notas dos alunos na Tarefa 3........................... 104

Tabela 4 - Frequência das notas na Tarefa 4 (2013) ................................ 108

Tabela 5- Comparativo da turma A - Antes e Depois da WQ ....................... 111

Tabela 6 - Comparativo da turma B - Antes e Depois da WQ ...................... 112

Tabela 7- Comparativo das medidas dos 29 alunos antes e depois da aplicação

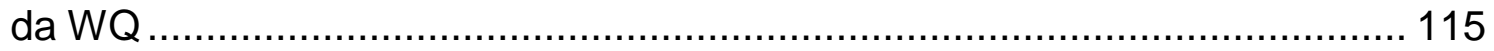





\section{Resumo}

Nas últimas décadas o aumento do acesso à Internet vem modificando a maneira como interagimos com a informação e, em consequência, com o conhecimento. A educação no mundo digital exige a adoção de novas metodologias de ensino que desenvolvam competências e habilidades necessárias a formação crítica, reflexiva e participativa de nossos educandos. Dessa maneira busca-se desenvolver a autonomia dos alunos em relação às escolhas que farão durante sua vida, fazendoas de maneira consciente e planejada. Considerando o baixo índice de acertos nas questões de porcentagens de um simulado realizado em uma escola estadual do interior do Estado de São Paulo foi elaborada a WebQuest "BMW Vermelho" com o objetivo de avaliar: Em que medida a metodologia WebQuest contribui para a aprendizagem de porcentagem? Durante a aplicação da WebQuest, em dois nonos anos do Ensino Fundamental, foi possível perceber como a metodologia, através da motivação, provoca mudanças no comportamento dos alunos no que diz respeito a disciplina, a concentração e o desejo em aprender o conteúdo, indicando uma grande potencialidade de uso em revisões de conteúdo, uma vez que deixa de ser uma repetição podendo ser uma maneira de apresentar novos significados aos temas revistos e promover a interdisciplinaridade.

Palavras-chave: WebQuest, Porcentagem, Educação Matemática. 



\begin{abstract}
Since the advent of technological age, the widespread use of Internet has been modifying the way we interact with information and, in consequence, with knowledge. The education in the digital and connected world requires the adoption of new teaching methodologies which seek for being innovative and that develop skills that a critical, reflexive, participative and professional formation of our students requires, reaching to develop their autonomy about the decisions they will take in their lives, by making them in a conscious and planned way. Observe that the importance of the content of percentage and the low index of right answers in questions of a test in a state school on the interior of São Paulo state, based on the questions of SARESP, it was elaborated the WebQuest "BMW Vermelho" with the objective to evaluate the use of review of content methodology. During the application of WebQuest, it was revealed how the methodology, trough the motivation, is associated with changes in the students behavior, in regards to discipline, concentration and the desire of learning the content, indicating a great potential in using review of contents, since it stops being a repetition and starts being a way of present new meanings to the themes reviewed and advocate interdisciplinarity.
\end{abstract}

Keywords: WebQuest, Percentage, Mathematics Education. 



\section{Sumário}

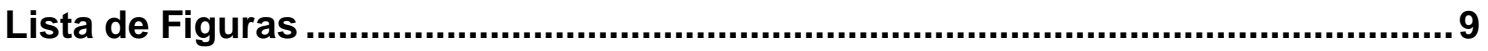

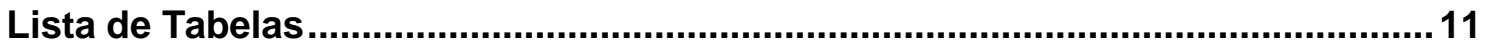

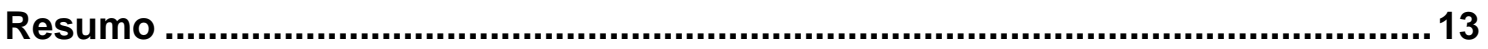

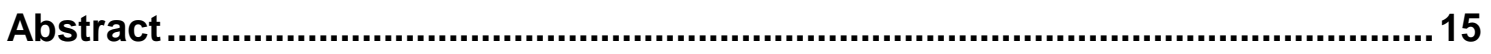

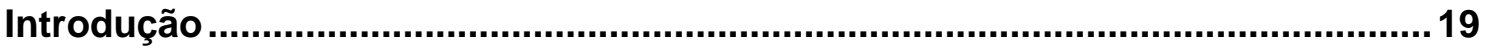

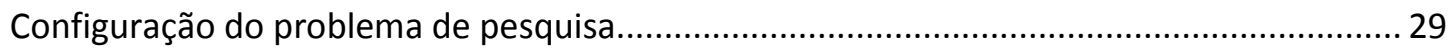

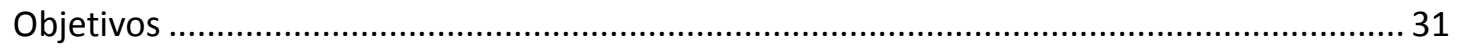

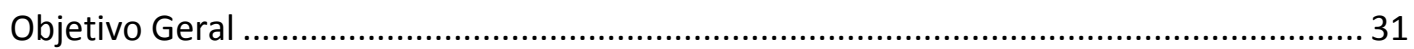

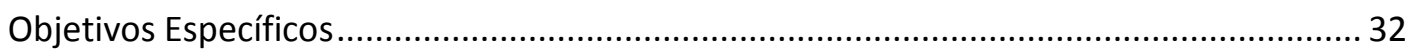

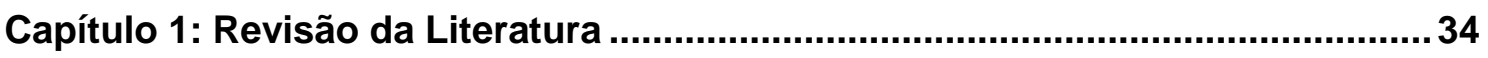

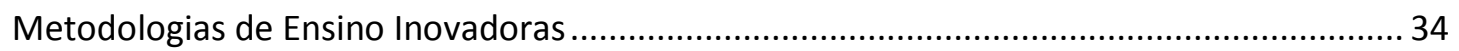

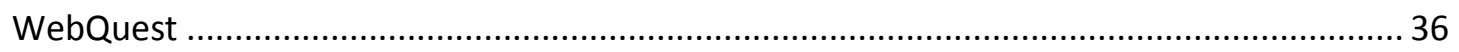

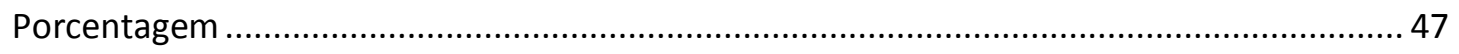

Porcentagem nos livros didáticos do Ensino Fundamental ...................................................... 56

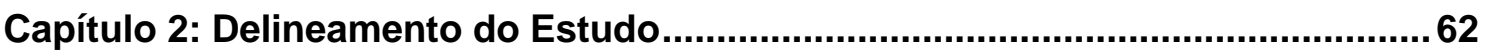

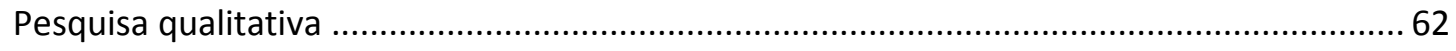

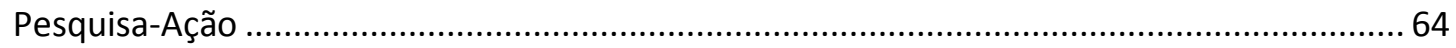

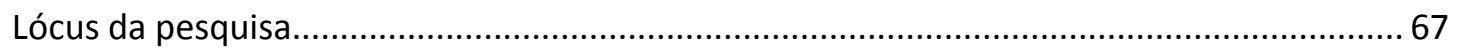

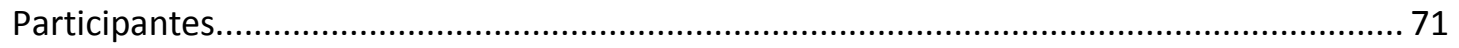

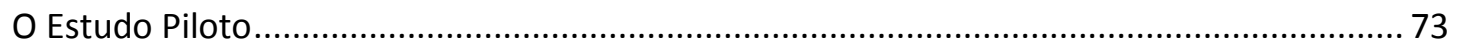

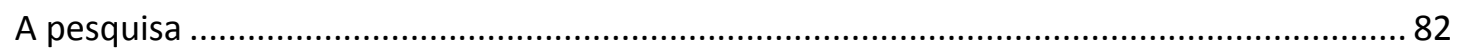

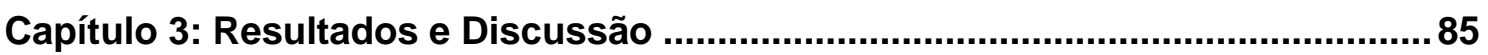

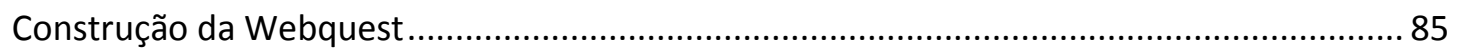

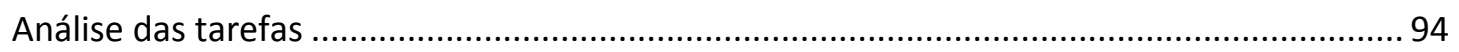

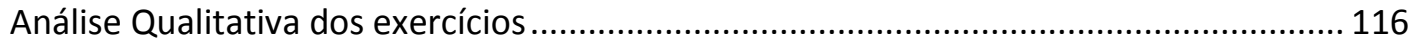

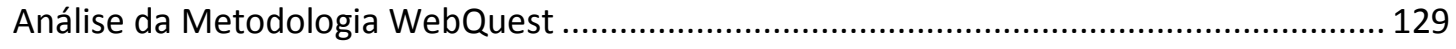

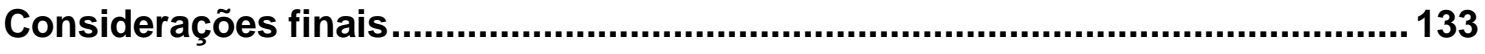

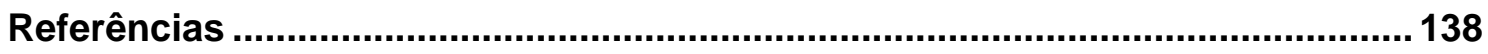





\section{Introdução}

Nas últimas décadas o aumento do acesso à Internet vem modificando a busca por informações e a interação entre as pessoas. Atualmente é pela rede que muitas pessoas realizam compras, planejam viagens, comparam produtos e têm acesso a bancos de dados com as mais diversas informações.

Esse panorama vem modificando a maneira como interagimos com a informação e, em consequência, com o conhecimento, dando cada vez mais novos sentidos à relação entre os dois conceitos. Memorizar nomes, datas, fórmulas e fatos não são mais sinônimos de conhecimento.

As informações estão à disposição na Internete, mas é preciso ir além, fazer análises, comparações e inferências. Configura-se assim um novo paradigma para educação na era digital. A seguir apresentarei dados que buscam caracterizar a utilização de computadores e Internet na sociedade e nas escolas brasileiras. Focarei em dados relativos à população com baixa renda, populações rurais e sobre a região sudeste devido a localização da escola, lócus da pesquisa e os seus participantes.

Analisando as pesquisas do Comitê Gestor da Internet no Brasil (FUNDAÇÃO GETÚLIO VARGAS, 2012), podemos mapear o crescimento da utilização de computadores e da Internet nos ambientes domésticos, escolares e empresariais. Os dados parecem apontar cada vez mais a necessidade de uma inclusão digital significativa na vida das pessoas, em especial aqueles economicamente desfavorecidas. 
Já a pesquisa de 2012 sobre a utilização das Tecnologias de Informação e Comunicação (TIC) em domicílios ${ }^{1}$ e empresas ${ }^{2}$ apresenta dados que apontam o crescimento da utilização das TIC nesses ambientes. "Nos últimos oito anos, a pesquisa TIC Domicílios revelou um crescimento constante na proporção de domicílios brasileiros com computador: 21 pontos percentuais entre 2008 e 2012" (BRASIL, 2013a, p. 156) que pode ser observado na Figura 1. É possível verificar ainda que quanto a utilização da Internet "o aumento foi de 22 pontos percentuais desde 2008, quando o percentual de domicílios com acesso à Internet era de 18\%." (BRASIL, 2013a, p. 159), tal crescimento pode ser visualizado na Figura 2, dividido em área rural e urbana.

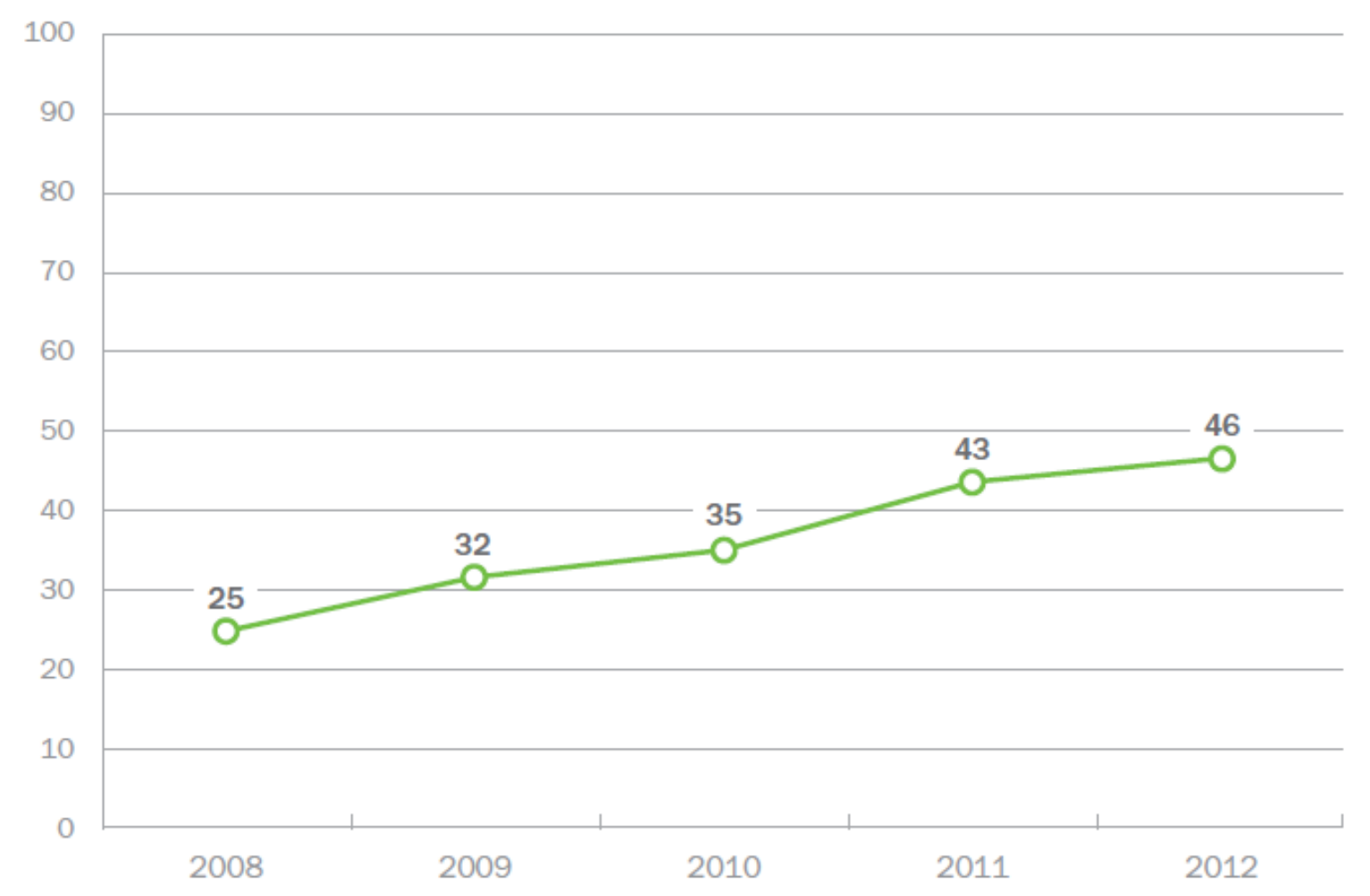

\footnotetext{
${ }^{1}$ TIC Domicílios: O tamanho total da amostra foi fixado em 17.760 entrevistas, distribuídas em todo o Brasil.

${ }^{2}$ TIC Empresas: a amostra inicialmente prevista foi de 6 mil empresas.
} 
Figura 1 - Proporção ${ }^{3}$ de domicílios com computador (2008 - 2012)

Fonte: BRASIL, 2013a, p. 156

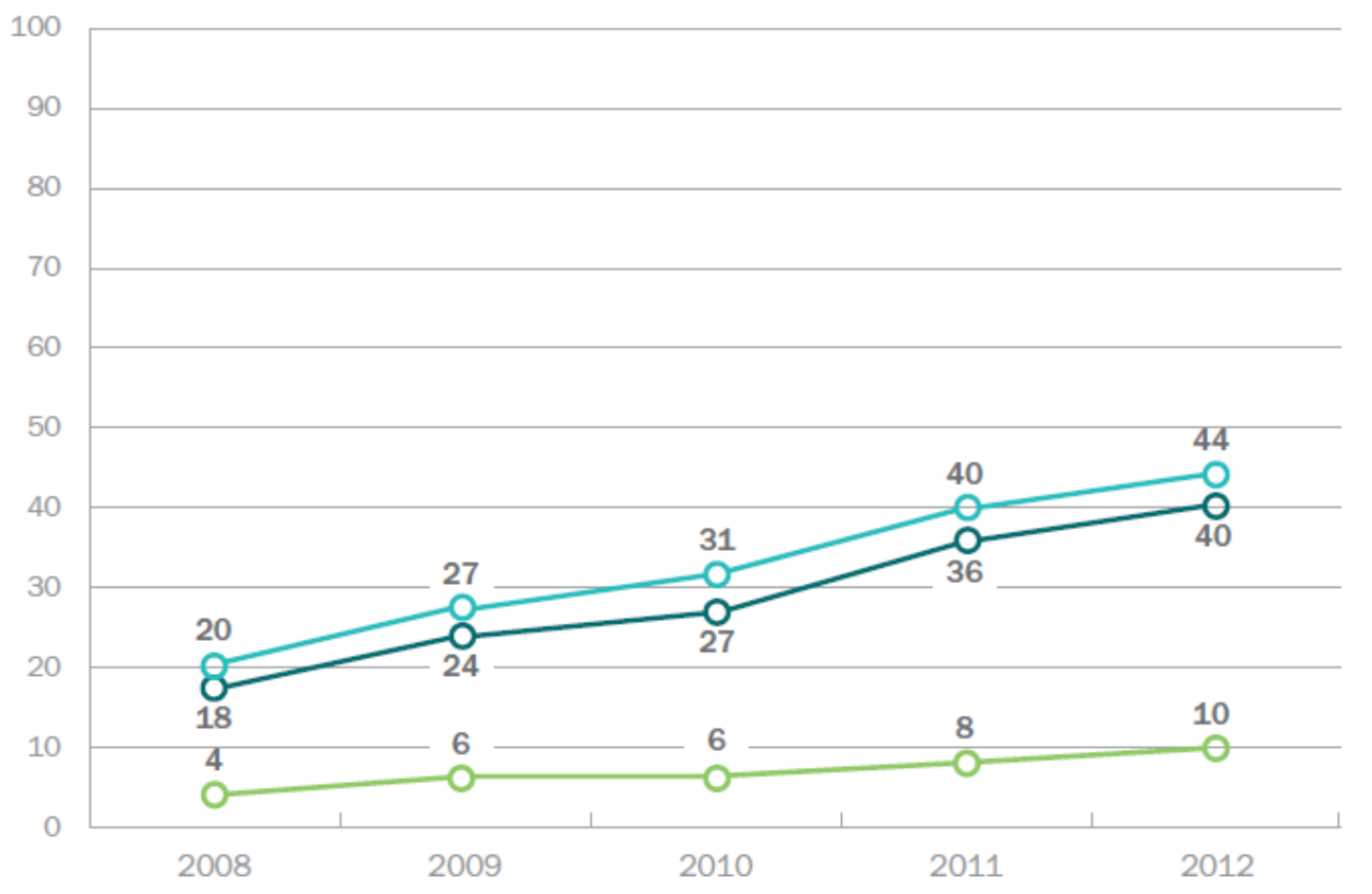

Figura 2 - Proporção de domicílios com acesso à Internet, por área (2008 2012) Percentual sobre o total de domicílios.

Fonte: BRASIL, 2013a, p. 159

Quanto a utilização de computadores e Internet em empresas, os dados são ainda mais contundentes e deixam clara a necessidade de domínio das TIC na procura de uma vaga no mercado de trabalho. Segundo a pesquisa, "a posse e o uso de computadores, assim como o acesso à Internet, estão difundidos em praticamente todas as empresas brasileiras com 10 ou mais pessoas ocupadas: 98\% das empresas possuem computador e $97 \%$ delas acessam a Internet (...)" (BRASIL, 2013a, p. 211). Na Figura 3 podemos perceber que esses índices

\footnotetext{
${ }^{3}$ A proporção representa o percentual de domicílios, foi mantido "proporção" como no documento original.
} 
vêm se alterando pouco ao longo dos últimos anos e praticamente atingiram-se os $100 \%$, mostrando-nos que passa da hora das escolas incorporarem o mundo digital em suas práticas.

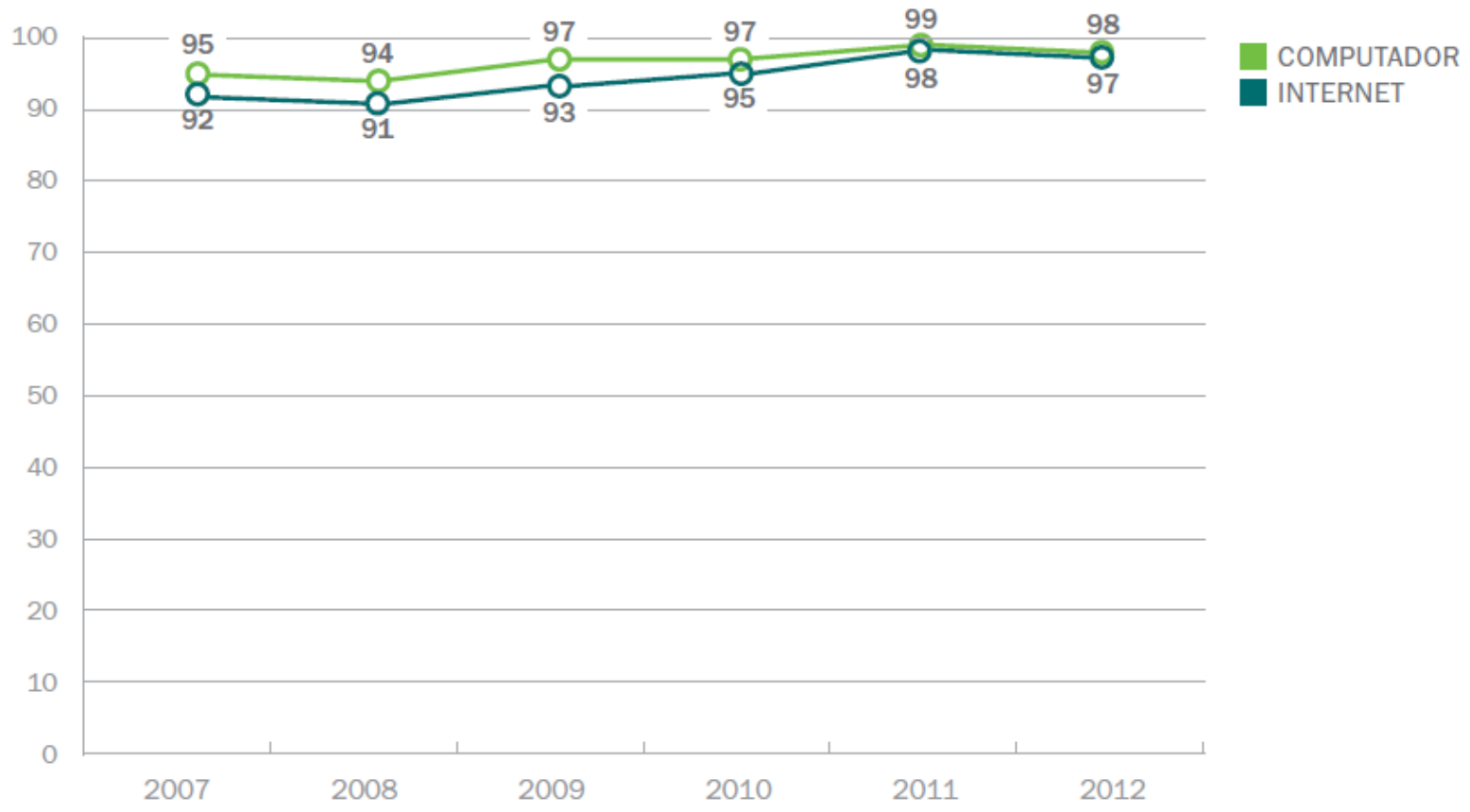

Figura 3 - Proporção de empresas que utilizaram computadores e Internet nos últimos 12 meses (2007-2012). Percentual sobre o total de empresas.

Fonte: BRASIL, 2013a, p. 211

Contudo, não basta analisar o crescimento quanto a utilização, é importante avaliar quem está utilizando. Entre as famílias das classes D e E somente 6\% possuem acesso a Internet, enquanto entre a classe A o índice é de 97\%. Outro fator a ser considerado é a diferença de acesso entre as pessoas residentes em áreas urbanas e rurais, "na zona rural, $78 \%$ dos indivíduos entrevistados declararam nunca ter utilizado a Internet, proporção que é de 40\% nas áreas urbanas" (BRASIL, 2013a, p. 167).

Podemos perceber a ampla diferença entre as famílias mais carentes e as mais abastadas, enquanto nas classes mais desfavorecidas a Internet quase não se 
faz presente, nas mais economicamente favorecidas, raro é não estar conectado. $O$ mesmo acontece quando comparamos áreas urbanas e rurais, ainda que consideremos que $60 \%$ da população urbana conectada seja um percentual baixo.

Se analisarmos o papel da Internet na sociedade atual, em um mundo globalizado, dinâmico e rápido, não ter acesso a rede passa a ser uma desvantagem em muitos sentidos. Na Internet encontram-se desde cursos gratuitos, oportunidades de emprego, opções culturais, entre outras coisas úteis em nosso dia a dia, até mesmo informações sobre o preço da gasolina e a localização do posto mais barato da sua cidade.

O que pretendo aqui é ilustrar o papel democrático da Internet que, pelo menos em teoria, possibilita o acesso aos mais diversos conteúdos sem distinguir classe social, nível escolar ou localidade, com informações mais atualizadas, diferentes pontos de vista e opiniões, oportunidades de trocar e conhecer novas ideias, um espaço para se expressar e conhecer.

Nesse contexto, as escolas acabam por ter papel fundamental na diminuição das distâncias de oportunidades entre pessoas de diferentes classes sociais ou pessoas residentes em diferentes áreas, rural e urbana, pois é na escola, que muitas dessas pessoas terão garantido o acesso à Internet, e mais do que isso, a orientação sobre sua utilização e exploração de recursos que auxiliem na formação cidadã e no pensar reflexivo.

Desta forma, o ideal seria que todas as escolas públicas brasileiras dispusessem de laboratórios de informática com acesso a Internet para o desenvolvimento das atividades pedagógicas com seus alunos. Contudo de acordo com o Censo Escolar da Educação Básica 2011(BRASIL, 2012b), essa realidade ainda está um tanto distante: os laboratórios de informática estavam presentes em 
$44,1 \%$ das escolas públicas de ensino fundamental do país e $42,6 \%$ das escolas possuíam acesso à Internet.

Considerando apenas as escolas públicas da região sudeste 67,9\% possuiam laboratório, e 72,6\% possuiam acesso à Internet. Tendo em vista que esta região é tida como a mais desenvolvida do país, não é de se espantar que ela apresente índices melhores quando comparados aos das demais regiões do Brasil. Entretanto é importante destacar que isto não significa necessariamente que haja uma maior utilização das tecnologias nas práticas didáticas nas escolas desta região.

Bibliotecas ou salas de leituras estavam presentes em apenas 40,2\% das escolas públicas brasileiras e as quadras de esportes estavam presentes em $27,5 \%$.

Na região sudeste esses índices eram $66,2 \%$ e 56,6\% respectivamente. Ou seja, em números, os livros e as quadras de esporte parecem que vêm perdendo espaço para a tecnologia, o que novamente pode evidenciar uma tendência a um novo modelo de educação.

Atualmente um computador com Internet tem acesso a mais livros do que qualquer biblioteca pode conter, as leituras acontecem cada vez mais em telas de computadores e os jogos são computacionais. Mas a importância tanto da sala de leitura como da quadra de esporte não devem ser diminuídas frente às tecnologias, principalmente quanto a prática de atividades físicas, forte aliado no desenvolvimento cognitivo e motor.

Porém, como dito anteriormente, somente a presença de laboratórios e Internet nas escolas, não garantem a sua real e eficaz utilização.

Embora os Parâmetros Curriculares Nacionais (BRASIL,1998) ressaltem a importância da utilização das tecnologias no ensino, e definam, entre outros, como 
objetivo do Ensino Fundamental, "saber utilizar diferentes fontes de informação e recursos tecnológicos para adquirir e construir conhecimentos" (p. 9), podemos notar, como exposto a seguir, que esse objetivo não vem sendo contemplado.

A atividade que a maior proporção de professores afirma utilizar computador e Internet com os alunos é o ensino de como usar computador e Internet: $62 \%$. Todavia, é realizada por apenas $28 \%$ dos docentes, mais da metade deles em frequência menor que uma vez por semana. Isso indica que o computador e a Internet ainda não são utilizados de forma a complementar à prática pedagógica, permitindo, por exemplo, outros métodos de ensino para as disciplinas curriculares como a utilização de softwares educacionais ou o uso das TIC em projetos aplicados. (BRASIL, 2013b, p. 170).

O fato é, saber utilizar recursos tecnológicos tornou-se imprescindível diante da quantidade de informações e o surgimento de novas teorias. Note que os Parâmetros Curriculares são de 1998, ou seja, esse foi um objetivo colocado há 16 anos atrás e que não vem sendo alcançado pois falta, entre outros aspectos, infraestrutura adequada e preparo docente para que exista uma inclusão significativa das TICs no ambiente educacional.

Para que a comunidade escolar usufrua plenamente dessas potencialidades, o investimento em infraestrutura - os atributos que permitem a difusão do acesso a essas tecnologias - não tem se mostrado suficiente. A integração das tecnologias às práticas pedagógicas depende de inúmeros outros fatores que levam, em uma análise mais aprofundada, a uma efetiva apropriação dessas ferramentas. (BRASIL, 2013b, p. 153) 
No sistema atual, as aulas, em geral, ainda possuem as mesmas estruturas do século passado: centradas no professor transmitindo informações, para o aluno que deve escutar pacientemente, reprimindo muitas vezes ideias e principalmente a energia dos jovens.

Depois os alunos são convidados a resolverem listas com exercícios repetitivos e por último são avaliados por meio de provas muitas vezes descontextualizadas que avaliam mais a precisão do cálculo do que a habilidade futura em utilizar aquela informação, e quem sabe um dia transformá-la em conhecimento.

Para uma mudança nesse sistema de ensino buscando adequá-lo ao mundo digital, necessidade cada vez mais latente, existe a promessa da inclusão digital nas escolas, mas será que essa inclusão tem acontecido de maneira significativa? Acredito que para surtir efeito não basta utilizar as TICs, temos que pensar em como utilizar, conhecer e criar novas metodologias pensadas em um ambiente computacional.

Uma inclusão significativa das tecnologias no desenvolvimento das atividades em aula, deveria colocar em contato direto o aluno e as tecnologias sob a orientação do professor para que a utilização das mesmas pudesse propiciar uma interação proveitosa e produtiva, afinal elas fazem parte de suas vidas e o cenário indica que passarão a fazer cada vez mais.

Uma condição fundamental para lidar com a complexidade de um novo currículo é incluir totalmente a escola na nova cultura digital: a construção dessa escola, sua estrutura, organização e funcionamento incorporados em uma cultura que privilegie e favoreça o funcionamento em rede, com mobilidade conectando espaço e tempo. (BRASIL, 2012a, p.51) 
Na realidade encontramos escolas pouco preparadas para esse novo modelo de educação exigido pelas transformações atuais: ainda faltam equipamentos, a Internet é lenta e compartilhada, os ambientes escolares não são propícios, falta disponibilidade nos laboratórios e "a esses problemas, somam-se a falta de formação dos professores, que não estão devidamente capacitados para formar cidadãos aptos para lidar com as necessidades de uma sociedade tecnológica e sua constante transformação" (MOREN e ROCHA, 2011, p. 1).

É claro que um novo modelo escolar traz consigo transformações em muitas esferas. Como o professor está em contato direto com os alunos, será ele o principal agente dessa transformação, e para isso deverá estar preparado, buscando novas metodologias e assumindo novas posturas frente a seus educandos e, principalmente, frente a sua maneira de entender e pensar 0 conhecimento.

A sociedade se transforma cada vez mais rápido, e somente um professor que esteja disposto a acompanhar essas mudanças estará preparado para aprender com seus alunos e auxiliá-los em suas experiências. $O$ professor que deseja inserir seus alunos nessa realidade deve ele também usar o computador e estar conectado.

Os dados da pesquisa do Comitê Gestor da Internet no Brasil ${ }^{4}$ em 2011 (BRASIL, 2012a) revelam que apenas $2 \%$ dos professores declararam não ter aprendido a usar o computador ou a Internet, o que pode indicar que os professores estão sendo preparados para ensinar nesta realidade. Porém, nesta mesma pesquisa evidencia-se que a busca por essa preparação não tem tido a contrapartida esperada dos governos: a maior parte dos professores que fizeram cursos de capacitação, $72 \%$, declarou ter feito com recursos próprios, enquanto

\footnotetext{
${ }^{4}$ Foram entrevistados 1822 professores, 606 coordenadores pedagógicos, 640 diretores e 6364 alunos, entre outubro e dezembro de 2011.
} 
apenas $21 \%$ o fez em programas de capacitação oferecidos pelos governos ou pelas Secretarias de Educação e 11\% pela própria escola. Na pesquisa de 2012 esses números foram, respectivamente, $75 \%$, $19 \%$ e $14 \%$, ou seja, enquanto cresce o percentual de professores que se capacitam através de cursos pagos com os próprios recursos e na própria escola, diminui os que realizam cursos oferecidos pelo governo ou pelas Secretarias de Educação.

Esses dados parecem indicar que os professores estão buscando se atualizar, mas que há falta de programas de incentivo para que isso ocorra o que dificulta a realização dos cursos e a utilização dessas tecnologias pelos professores.

Com relação à falta de preparo, há de se levar em consideração que saber utilizar as TIC não basta, para incorporá-las nas aulas. É necessário conhecer e conceber novas metodologias e novas maneiras de interação com os conteúdos. Logo, faz-se cada vez mais necessária a criação de cursos de capacitação docente, não se esquecendo de garantir a esses professores uma jornada e remuneração que os possibilite realizar e aproveitar verdadeiramente esses cursos.

Uma possibilidade seria oferecer cursos que utilizem como medotologia de ensino, aquelas metodologias que pretendem ensinar pois ter contato com a metodologia sem vivenciá-la, embora possa ser proveitoso para alguns professores, acaba reproduzindo a lógica das aulas de outrora, deixando a maioria sem saber como, de fato, aplicar aquilo que foi "transmitido" sobre a metodologia.

Outra maneira de auxiliar os professores em busca de novas práticas e metodologias que os ajudem a inserir as tecnologias em suas aulas é a divulgação de experiências exitosas.

Nesse sentido, essa pesquisa tem por objetivo analisar o uso de uma metodologia de ensino que privilegia a utilização das TICs. 


\section{Configuração do problema de pesquisa}

Ao final do nono ano do Ensino Fundamental os alunos da rede pública são avaliados pelo Sistema de Avaliação do Rendimento Escolar do Estado de São Paulo (SARESP), uma avaliação externa que busca oferecer à Secretaria de Educação do Estado de São Paulo, desde 1996, informações sobre o desempenho do ensino em cada escola e Diretoria de Ensino.

Seguindo as orientações da coordenadora pedagógica de uma escola estadual do interior de São Paulo, realizamos em 2012 um simulado, nos moldes da avaliação do SARESP, com os alunos do nono ano para diagnosticar quais Habilidades e Competências dominavam e quais necessitavam ser aprimoradas durante o ano, bem como apresentar conteúdos que seriam cobrados na avaliação mas que devido às perdas de dias letivos, ainda não haviam sido abordados.

Durante a correção do simulado foi possível perceber que os alunos das duas turmas de 2012 cometeram muitos erros em questões que envolviam porcentagem, proporcionalidade ou cálculos com números racionais, o que era condizente com as lacunas conceituais identificadas em avaliações diagnósticas anteriores.

Segundo a Proposta Curricular do Estado de São Paulo (SÃO PAULO, 2008) o conteúdo Média Aritmética deve ser explorado no 4ํㅜ bimestre do 6ํAno do ensino fundamental. Operações com números racionais devem figurar nos conteúdos do $1^{0}$ bimestre do $7^{\circ}$ Ano e no $3^{\circ}$ bimestre do mesmo ano devem ser tratados os conceitos de proporcionalidade e porcentagem.

Já era de conhecimento do professor a dificuldade dos alunos em porcentagem mas como o atraso $^{5}$ no aprendizado era grande, o assunto não foi trabalhado com o tempo necessário para uma aprendizagem significativa por parte

\footnotetext{
${ }^{5}$ Cabe ressaltar que devido a safra, ou faltas referentes a feriado em meio de semana, os alunos perdiam muitos dias letivos durante o ano escolar.
} 
dos alunos. A maioria não gostava e criava até mesmo uma barreira para estudar porcentagem, não se sentindo capazes de aprender. É possível que essas barreiras sejam provenientes do formalismo na apresentação do conteúdo em aulas tradicionais. Uma abordagem teórica e centralizada no professor poderia distanciar o aluno do conteúdo.

Além disso, quando se falava em porcentagem nessas salas, antes mesmo de se apresentar um exercício ou explicação, as reclamações eram frequentes. A partir disso buscou-se uma metodologia diferenciada que pudesse auxiliar o trabalho em sala de aula a fim de estimular os alunos a entrarem em contato novamente com um conteúdo ao qual não apresentavam rendimento satisfatório e de uma forma mais dinâmica.

No mesmo ano que ingressei na escola pesquisada, 2011, matriculei-me na primeira turma do Programa de Mestrado Profissional em Rede Nacional PROFMAT, no Instituto de Ciências Matemáticas e da Computação da Universidade de São Paulo, campus São Carlos, onde revisitei e ressignifiquei alguns conteúdos matemáticos, além de perceber e discutir sua importância.

Durante as aulas o clima foi sempre de muita colaboração entre os professores-alunos e os professores-professores, e todos aprendíamos mais sobre os conteúdos e os métodos de abordagens. O enfoque era sempre matemático mas era impossível não discutir metodologia de ensino, trocar ideias e sugestões, ir a lousa e participar. Concluí as disciplinas com a certeza de que dominava melhor os conteúdos e que todo aquele contato mudaria minha prática em sala de aula.

O programa de mestrado tem um enfoque conteudista o que certamente me trouxe mais confiança em sala de aula, principalmente nas aulas do Ensino Médio de uma escola particular em que comecei a lecionar no ano de 2012. 
Contudo eu procurava para a dissertação algo diferente e quando fui apresentado à metodologia da WebQuest, considerei que ela possuía potencialidades formativas, pois integrava as estratégias que eu, enquanto professor, utilizava em sala de aula, com um meio privilegiado de aprendizagem, o computador, a Internet e uma nova forma de proceder a avaliação.

Decidi então iniciar os estudos sobre a metodologia de ensino com a utilização de WebQuests - WQs, os principais conceitos relacionados, trabalhos sobre como elaborar uma WQ, a importância do planejamento, ler dissertações sobre a utilização de WQ, principalmente no ensino de matemática, e procurar WQ a fim de conhecer melhor a apresentação e os passos necessários a realização da mesma.

Inicialmente cogitei avaliar WQs já publicadas por outros professores, mas a partir da necessidade de rever alguns conteúdos, decidi elaborar uma WQ. O curta metragem (BMW Vermelho) me serviu de inspiração para a construção da WQ que seria a base da minha pesquisa de mestrado.

Desta forma o seguinte problema de pesquisa esquadrinhou-se: Em que medida a metodologia WebQuest contribui para a aprendizagem de porcentagem?

\section{Objetivos}

\section{Objetivo Geral}

A presente pesquisa tem por objetivo geral analisar o uso da metodologia de ensino - WebQuest (WQ) - que privilegia a utilização das Tecnologias da Informação e Comunicação (TIC), em duas turmas de alunos do nono ano do Ensino Fundamental de uma escola pública estadual do interior de São Paulo. 


\section{Objetivos Específicos}

- Identificar fatores no uso da WebQuest que podem contribuir para a aprendizagem de porcentagem;

- Investigar se há melhora na resolução de problemas que envolvem porcentagem;

- Analisar a aplicação da metodologia de WebQuest nas aulas de Matemática em uma escola pública estadual do interior do Estado de São Paulo.

A apresentação desse estudo se dará em quatro capítulos. Na introdução buscou-se contextualizar o estudo e sua importância, bem como definir o problema e os objetivos da pesquisa.

O capítulo 1 traz uma revisão de estudos sobre as metodologias de ensino inovadoras e a WebQuest, além de alguns estudos realizados sobre o uso das mesmas no processo de ensino e aprendizagem, em especial, em Matemática. Ainda, no capítulo 1, serão apresentados os conteúdos estudados pelos alunos durante a WQ e possíveis explicações para o insucesso dos alunos em aprender conteúdos matemáticos.

O capítulo 2 descreve a metodologia: o problema de pesquisa e os objetivos são retomados e o lócus da nossa pesquisa, participantes e procedimentos de coleta e análise de dados são apresentados. Neste capítulo encontram-se ainda algumas considerações sobre o estudo piloto, realizado em 2012, que pautou mudanças para a pesquisa realizada em 2013.

O capítulo 3 apresenta o processo de construção da WQ BMW vermelho e análises das tarefas da WQ, das resoluções da lista de exercícios realizadas pelos alunos e da utilização da metodologia de WQ.

No capítulo de Considerações Finais são retomados nossos objetivos e alguns pontos da análise da utilização da WQ. Buscou-se nesse capítulo levantar 
as dificuldades, os principais resultados, quantitativos e qualitativos, e estimular a utilização da metodologia por outros professores. 


\section{Capítulo 1: Revisão da Literatura}

No presente capítulo são apresentadas metodologias de ensino em matemática consideradas inovadoras, a saber, jogos, resolução de problemas e modelagem matemática, salientando suas características e evidenciando como principal paradigma a mudança de postura do professor e a atuação dos alunos dentro dessas metodologias.

A seguir é apresentada a metodologia de WQ. A estrutura da metodologia é apresentada acompanhada de sugestões para a construção e uma revisão de estudos realizados sobre o uso da WQ no ensino, principalmente de conteúdos matemáticos.

Por fim são apresentados trabalhos sobre o conteúdo matemático de porcentagem, bem como a maneira como vem sendo tratado tal conteúdo nos livros didáticos.

\section{Metodologias de Ensino Inovadoras}

Diante de novos paradigmas para a educação no mundo digital e conectado, onde as informações estão disponíveis na grande rede mundial de computadores, se faz urgente a adoção de novas metodologias de ensino, que busquem ser inovadoras e que desenvolvam as competências e habilidades necessárias a formação crítica, reflexiva, participativa e profissional de nossos educandos, para que possam estar em constante aprendizado mesmo fora do ambiente escolar, integrando o conhecimento desenvolvido dentro da escola com as situações cotidianas e se apropriando desse conhecimento para entender e interagir com o mundo ao seu redor. 
Um ensino que busque desenvolver a autonomia ${ }^{6}$ dos alunos em relação as escolhas que farão durante sua vida, fazendo-as de maneira consciente e planejada.

O foco das metodologias ativas é a experiência vivenciada pelo aluno no desenvolver de atividades previamente organizadas para que desenvolvam habilidades e competências consideradas necessárias para uma formação crítica e que estimule a participação, favorecendo a atuação reflexiva e cidadã na sociedade.

Muitas são as metodologias de ensino em Educação e, especificamente, em Educação Matemática, que podem contribuir para que o aluno seja um ser ativo na construção de seu próprio conhecimento e ao professor cabe a importante função de motivar e mediar a relação entre o aluno e a informação.

Com os novos paradigmas da educação e com as informações a disposição, perde o sentido uma aula que tenha como objetivo somente transmitir o conteúdo. Dessa maneira os atores do ambiente escolar devem assumir outros papéis.

Nas metodologias que buscam ser inovadoras, o professor assume o papel de mediador, de facilitador da construção do conhecimento, que tem agora como agente principal o aluno. É o aluno quem deve agir, quem deve produzir, tornando assim o aprendizado mais significativo para ele mesmo, desenvolvendo sua autonomia, sua capacidade reflexiva.

Note que de maneira alguma ao professor cabe uma posição menos importante se comparado às metodologias tradicionais, ao contrário, um professor que busca utilizar de metodologias inovadoras precisa estar em constante atualização, pois caberá a ele desenvolver capacidades que antes não eram estimuladas.

\footnotetext{
${ }^{6}$ Aptidão ou competência para gerir sua própria vida, valendo-se de seus próprios meios, vontades e/ou princípios.
} 
Quando entrei em contato com a WebQuest, percebi tratar-se de uma metodologia que permite reunir dentro de uma única situação de aprendizagem, as tecnologias, as novas metodologias de ensino centradas no aluno e em resolução de problemas, e a formação crítica-reflexiva do educando, hoje indispensáveis para o desenvolvimento da autonomia e da participação consciente na sociedade.

\section{WebQuest}

O termo WebQuest (WQ) designa uma metodologia de ensino baseada na utilização de recursos presentes na Internet, desenvolvida na San Diego State University por Bernie Dodge e Tom March, (SILVA, 2006a).

Em uma WQ o professor deve cumprir o papel de mediador, orientando a navegação de seus alunos pelos vastos conteúdos da Internet, selecionando informações relevantes e apontando links confiáveis para pesquisa.

As WQ podem ser divididas em pelo menos dois níveis: as curtas, com duração de duas ou três aulas e as longas, com duração de uma semana a um mês de trabalho.

A grande quantidade de informações disponíveis na rede pode, muitas vezes, atrapalhar o processo de ensino/aprendizagem, logo o que a WQ propõe é um planejamento do professor para direcionar as pesquisas e as tarefas realizadas pelos alunos.

A Figura 4, ilustra as partes essenciais de uma webquest: Introdução, Tarefas, Processo, Avaliação e Conculsão. 


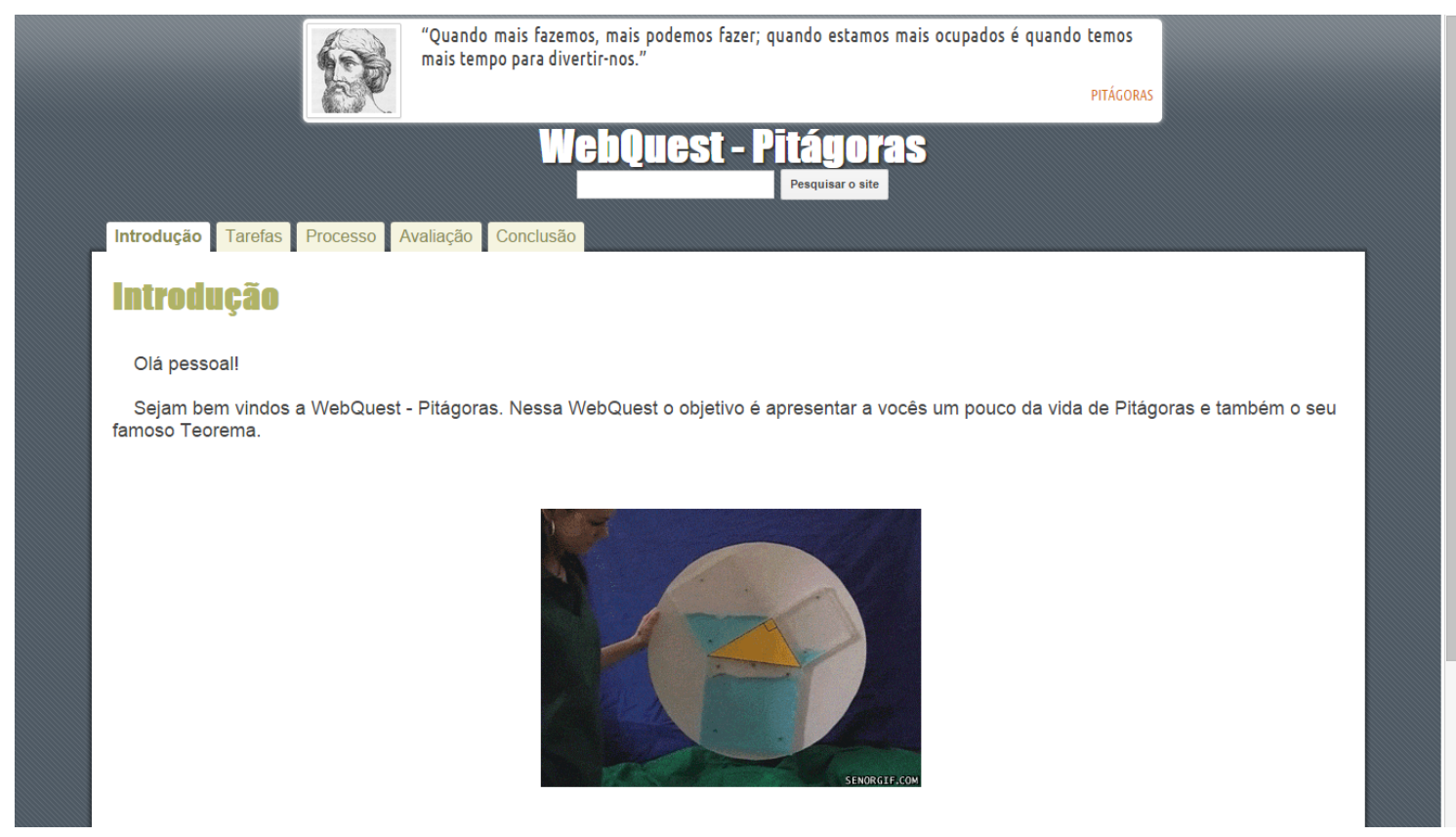

Figura 4 - Exemplo de WebQuest - Fonte própria.

Dodge(1995) descreveu as partes essenciais de uma WQ:

1. Introdução: constitue-se de um pano de fundo para o trabalho que será desenvolvido, deve apresentar informações sobre qual será o tema estudado e procurar despertar a curiosidade dos alunos motivando-os a realizar as tarefas.

2. Tarefas: são ações que devem ser executadas pelos alunos e devem conduzir os trabalhos de pesquisa, organização, reflexão e conclusão sobre o tema estudado. Uma lista de tarefas motivadoras e adequadas aos conhecimentos prévios da turma deve ser planejada pelo professor de acordo com o foco do estudo. Pode ser um questionário, um relatório, uma 'tabela, a produção de uma carta, a criação de poster ou maquetes explicativas, até listas de exercícios para verificar como os alunos resolvem novos problemas propostos a partir da situação explorada.

3. Processo: Refere-se a um rol de links e fontes de pesquisas previamente selecionadas pelo professor, que auxiliem na realização das tarefas propostas. Os recursos podem ser os mais variados, vídeos, músicas, artigos, livros, sites de vendas de produtos, simuladores, enfim tudo aquilo que está presente na Internet e 
pode auxiliar o aluno a entender e realizar as tarefas. O principal objetivo aqui é orientar o aluno nas buscas e evitar que ele se perca em seu trabalho ou busque fontes pouco confiáveis. Uma descrição clara e objetiva dos processos que devem ser executados, pelos alunos, na realização das tarefas. O professor deve conhecer a turma para saber o que é relevante indicar sobre o processo de realização da tarefa a partir da familiaridade dos alunos com os processos envolvidos.

4. Avaliação: Orientar sobre como organizar as informações encontradas na rede e como essa organização será avaliada pelo professor. A informação por si só não produz conhecimento, é preciso saber organizá-la para facilitar sua análise e construir significados.

5. Conclusão: parte onde ficam evidenciados os objetivos alcançados pelos alunos e os estimule a utilizar esse conhecimento em outras situações.

As WQ geralmente propõem atividades em grupos mas não há nada que a impeça de ser uma atividade individual. Os grupos favorecem o contato social e estimulam a comunicação, colaborando para a formação de um pensamento crítico ${ }^{7}$ e refinado, por isso são preferidos os grupos ao trabalho individual.

Além do mais, o trabalho em equipe é exigido na sociedade atual e a escola deve propiciar momentos onde a interação entre os alunos seja algo produtivo, ensinando-os a ouvir e refletir sobre uma ideia diferente ou exigindo um maior esforço cognitivo ao apresentar suas ideias aos colegas.

Um elemento motivacional pode ser agregado, por exemplo, levando os alunos a desempenharem papeis, assumindo uma personagem (cientista, político, empresário ou mesmo um pai de família planejando as férias).

\footnotetext{
${ }^{7}$ Um processo de reflexão sobre as hipóteses que permeiam as nossas idéias e ações, bem como as dos outros, reconhecendo como o contexto altera comportamentos, resultando em novas formas alternativas de pensar e viver. (BROOKFIELD apud LIMA, 2000)
} 
Outro fator que pode enriquecer a WQ é utilizar uma abordagem multidisciplinar, complementando o conhecimento entre as disciplinas e dando novos significados a velhos conteúdos.

Como a WQ está disponível online existe a facilidade de que dois ou mais professores a utilizem em suas aulas. Por exemplo, o professor de Matemática pode calcular o quanto de gás carbônico $\left(\mathrm{CO}_{2}\right)$ é emitido por um carro, um ônibus e uma moto, depois calcular qual a emissão na cidade toda. Em outra aula o professor de Ciências pode explorar os efeitos dessas emissões para o meio ambiente, propor maneiras de se diminuir a poluição, enquanto o professor de Língua Portuguesa pode solicitar a produção de um relatório sobre a poluição e explorar seu conteúdo com ajuda da ferramenta matemática contextualizada.

A maneira como se dá o acesso à informação em uma WQ é a mesma que vem sendo utilizada cada vez mais no cotidiano: é cada dia mais comum a utilização da Internet para realizar pesquisas rotineiras, desde a busca por receitas a galerias de arte.

A aplicação dessa metodologia pode levar os alunos a tirarem o melhor proveito das informações espalhadas pela rede, organizá-las e interpretá-las, fazer análises e inferências, participando ativamente da construção de seu conhecimento não mais esperando as próximas lições, exemplos e exercícios repetitivos que visavam a retenção de um conteúdo muitas vezes esquecido logo após as provas.

O desenvolvimento da WQ coloca o aluno em ação e o professor como um mediador. O professor orienta, mostra caminhos, mas é o aluno que busca a informação, não mais a recebe, é o aluno quem faz as análises, ao professor cabe acompanhar o desenvolvimento das mesmas e assim realizar avaliações qualitativas da aprendizagem enquanto presencia o desenvolvimento do aluno na realização das tarefas. 
Dentre as metodologias que vem sendo pesquisadas (SMOLE, 2008; GIL,2006; BARBOSA, 2007; Grando 1995) chamam minha atenção ainda, os jogos, a resolução de problemas e a modelagem matemática pois colocam o aluno em ação dentro da sala de aula ressignificando a aula de matemática e os conteúdos matemáticos estudados na busca de uma aprendizagem que seja significativa ao educando e Ihes propicie condições necessárias para que possa utilizar a matemática em seu dia a dia.

A metodologia de ensino baseada no uso dos jogos poderá permitir, segundo Smole, Diniz, Pessoa e Ishihara (2008, p. 18), que os alunos "comecem a pensar sobre um novo assunto, ou para que eles tenham um tempo maior para desenvolver a compreensão sobre um conceito, para que eles desenvolvam estratégias de resolução de problemas ou para que conquistem determinadas habilidades que naquele momento você vê como importantes para o processo de ensino aprendizagem".

As autoras defendem que há dois tipos de jogos matemáticos que podem ser utilizados nas aulas: os de estratégia e os de conhecimento. Nos jogos de estratégias o objetivo é desenvolver estratégias vencedoras reconhecendo a regra e as melhores jogadas a se fazer. Esse tipo de jogo simula "processos de investigação matemática, resolução de problemas, levantamento, comprovação ou refutação de hipóteses" (SMOLE et al, 2008, p.13). São jogos que desenvolvem maneiras de pensar comumente utilizadas em matemática, como a indução e a generalização.

Os jogos de conhecimento fazem referência direta a tópicos estudados em matemática e são "um recurso para um ensino e uma aprendizagem mais rica, mais participativa e problematizadora dos temas matemáticos" (SMOLE et al, 2008. p.12). 
O jogo é visto como motivador no ambiente educacional uma vez que procura atingir o aluno de uma maneira lúdica, alterando a sua realidade mesmo que por instantes. Os jogos em educação procuram sempre propor uma interação entre dois ou mais participantes, estimulando o aprendizado em grupo, atrelado ao fator de desenvolver habilidades sociais importantes para o desenvolvimento crítico e participativo dos alunos.

Os jogos e a WQ podem se aproximar quando buscam criar um ambiente lúdico para o aluno. Em algumas WQ são sugeridos que os alunos assumam personagens ou auxiliem personagens conhecidos da história, livros ou cinema a resolver algum problema, como por exemplo uma WQ sobre lugares geométricos disponível em http://ilmc.no.sapo.pt/lg/index.htm, onde o personagem Harry Potter pede a ajuda dos alunos após receber uma mensagem secreta.

Além disso, nada impede que jogos sejam utilizados durante a WQ que busca ser mais uma maneira de inserir as TICs no processo de ensino aprendizagem do que uma metodologia limitada a um formato específico de atividade.

Também contribuindo para o desenvolvimento crítico e participativo dos alunos, tem-se a metodologia de resolução de problemas. A aprendizagem baseada em problemas (ABP), segundo Gil (2006):

[...] é uma estratégia em que os estudantes trabalham com o objetivo de solucionar um problema. Trata-se, portanto, de uma estratégia de ensino centrada no estudante, que deixa o papel de receptor passivo e assume o de agente e principal responsável pelo seu aprendizado. $\mathrm{Na}$ ABP os professores não atuam da maneira tradicional, mas como facilitadores do trabalho dos estudantes, auxiliando-os, por exemplo, com a indicação de recursos didáticos úteis para cada situação. (GIL, 2006, p. 175-176) 
Segundo Grando (1995), há 3 interpretações para Resolução de Problemas:

- Como objetivo final: ensina-se a teoria, o conteúdo, para resolver problemas.

- Como processo heurístico: desenvolve-se o potencial heurístico do aluno como resolvedor de problemas; objetiva-se aprimorar a escolha de estratégias.

- Como ponto de partida: o problema "dispara" o movimento de aprendizagem, ou seja, o problema é visto como desencadeador da formação de conceitos matemáticos; há a valorização do raciocínio abdutivo. Cada interpretação pode ser utilizada dependendo do que se busca desenvolver nos educandos. Das três interpretações considero a mais interessante a terceira, em que o problema serve de motivação para que os alunos, mediados pelo professor, resolvam-no e percebam a matemática presente na resolução, posteriormente sistematizando o conteúdo a ser aprendido e se possível aplicando o conhecimento recém-construído ou aprimorado em outras situações problemas.

Essa interpretação pode, também, ser encontrada em WQs quando as mesmas trazem um desafio ou uma situação problema para os participantes. Aliando um desafio ao lúdico consegue-se uma maior ligação entre aluno e problema, colocando-os em contato direto e fazendo com que o problema seja interessante e instigante. No caso de séries mais avançadas, ou no ensino superior, seria interessante que os alunos percebessem e modelassem problemas que podem surgir nos mais diferentes contextos, nesse sentido a WQ pode se aproximar também da Modelagem Matemática.

A Modelagem Matemática é uma metodologia de ensino que busca criar um modelo matemático a partir de um problema real e através desse modelo explorar o conteúdo matemático. "Entendemos por prática de Modelagem Matemática dos 
alunos as ações que eles desenvolvem no ambiente desencadeado pelo professor para abordar uma situação pertencente ao dia-a-dia ou a outras áreas do conhecimento" (BARBOSA, 2007, p. 4).

Novamente nessa metodologia, como citado nas outras duas, a saber jogos e resolução de problemas, o foco da aula desloca-se para os alunos. Cabe aos alunos a ação de modelar o problema em questão com o auxílio e a mediação do professor, que deve ajudar a organizar as ideias que surgirão buscando guiar os alunos na construção do saber.

$$
\begin{aligned}
& \text { Como usualmente grande parte do ambiente de Modelagem } \\
& \text { Matemática é desenvolvido através das discussões dos alunos } \\
& \text { organizados em grupo, podemos assumir que as interações } \\
& \text { desenvolvidas entre os alunos e entre estes e o professor se } \\
& \text { constituem em subsídios para a construção dos modelos matemáticos. }
\end{aligned}
$$
(BARBOSA, 2007, p. 4)

Em relação às WQ, muitos trabalhos vêm sendo produzidos no Brasil e no mundo, principalmente na última década, sobre a utilização da metodologia no ensino em geral e no ensino de matemática. A seguir são destacados alguns trabalhos sobre o tema.

O primeiro trabalho com o qual tive contato foi a dissertação de mestrado WEBQUEST: UMA METODOLOGIA PARA A PESQUISA ESCOLAR POR MEIO DA INTERNET, (SILVA, K. X. S, 2006). A pesquisadora desenvolveu a WQ "Alimentação Saudável" que foi aplicada a alunos da terceira série do ensino fundamental de uma escola pública de Taguatinga-DF, com o objetivo de analisar o uso da Internet como recurso pedagógico para a realização de pesquisas escolares.

Os dados obtidos indicaram que para a pesquisa escolar, a WebQuest como metodologia facilitou a busca e organização das informações encontradas na 
Internet, contribuindo para a construção do conhecimento. Além disso, promoveu a motivação dos alunos na realização de pesquisas uma vez que os orientou com links para auxiliar a navegação, evitando que o educando navegasse por sites pouco confiáveis ou se perdesse frente a grande quantidade de informações presentes na rede.

A WQ desenvolvida trabalhou com um conceito que faz parte, ou deveria fazer, do dia a dia das pessoas, a alimentação saudável. Isso me influenciou a aproveitar a oportunidade da elaboração e aplicação da WQ para trabalhar um tema relacionado ao consumo e ao meio ambiente, dois temas transversais importantíssimos para o desenvolvimento do cidadão.

Cruz (2006) investigou por meio da WQ "Lugares Geométricos” (disponível em http://ilmc.no.sapo.pt/lg/index.htm), conteúdos de geometria aplicados a alunos do $8^{\circ}$ ano do EF de Portugal. A WQ aliava os conteúdos matemáticos à motivação de resolver enigmas para ajudar Harry Potter a salvar sua escola.

Segundo a pesquisadora tanto ela quanto os alunos consideraram que a aplicação da WQ trouxe vantagens quanto a motivação para estudar os temas e a compreensão dos mesmos. E ainda, acreditavam que isso aconteceu, em grande parte, pelo contexto proposto no enredo da WQ.

Nesse sentido a WQ Lugares Geométricos serviu-me de referência para elaborar uma situação em que os alunos assumissem o problema como sendo seu problema, e isso foi alcançado, em alguns casos, de maneira lúdica. Alunos criaram enredos e se colocaram como personagens, o que indicou a possibilidade de se explorar a criatividade dos alunos por meio da WQ.

Durante o XI ENCONTRO NACIONAL DE EDUCAÇÃO MATEMÁTICAENEM, em 2013, muitos trabalhos sobre WebQuest foram apresentados. Barros e Scherer (2013), por exemplo, descreveram o caminho metodológico percorrido 
para analisar os resultados da investigação que teve como foco identificar as possibilidades de interação e pesquisa na etapa Tarefa de uma WQ de álgebra selecionada pelas pesquisadoras dentre as que estavam disponibilizadas no EscolaBR. Com autorização do professor-autor da WQ: "Aplicação da Matemática Financeira no Cotidiano" as autoras a definiram como objeto do estudo em questão. Os dados obtidos evidenciaram que as tarefas analisadas contemplavam: a generalização de padrões aritméticos, o estabelecimento de relação entre duas grandezas, a resolução de problemas que levam a diferenciação de parâmetros, variáveis e incógnitas, aspectos importantes para o desenvolvimento do pensamento algébrico.

Na comunicação WEBQUEST: AUXILIANDO NA REVISÃO DE CONTEÚDOS, Oliveira et al (2013) apresentaram um trabalho em desenvolvimento em dois colégios estaduais do Paraná, visando a revisão de conteúdos matemáticos do ensino fundamental, no primeiro ano do ensino médio, com foco principalmente em equações do primeiro e segundo grau, e retomando, quando necessário, raízes, potências, frações entre outros conteúdos inerentes aos cálculos.

O trabalho estava sendo desenvolvido por graduandos participantes do Programa Institucional de Bolsas de Iniciação à Docência (PIBID-UFPR), que nesse Campus é subdividido em três grupos: raciocínio lógico, mídias e laboratório de matemática. Os alunos do grupo de mídias desenvolveram as WQs com o intuito de ajudar o trabalho da professora da sala na revisão realizada no começo do ano letivo.

Os autores ressaltaram como ponto positivo da metodologia, a motivação dos alunos para realizar as tarefas de revisão, por buscarem novas maneiras de interação com conteúdo, o que, esperavam os autores, pudesse servir para uma aprendizagem significava e também como uma porta de entrada para outras mídias. 
De fato as WQs abrem espaço para a inserção de músicas, vídeos, jogos, programas de tv, programas de computador, revistas, infográficos, entre outras tantas mídias durante a sua realização. Cabe ao professor julgar o que pretende e como pode inserir essas mídias no decorrer da atividade.

Outro fator interessante no trabalho apresentado por Oliveira et al (2013), diz respeito ao fato de alunos graduandos estarem em contato direto com a metodologia: acredita-se que eles possivelmente estarão mais preparados e confiantes para utilizarem as novas metodologias em suas carreiras profissionais. É importante que os licenciandos sejam estimulados a interagirem com esses metodologias de ensino, assim como é desejável, que quando possível estudem a metodologia através da própria metodologia, experenciando o conhecimento que Ihes está sendo ensinado.

Tão importante quanto uma boa formação durante a graduação é capacitar professores já formados a utilizarem a metodologia, e nesse sentido, durante o XI ENEM, três minicursos tinham como tema central WQs: "WEBQUESTS NO ENSINO E APRENDIZAGEM DE MATEMÁTICA" Azevedo et al (2013), "WEBQUEST: ELO ENTRE A MATEMÁTICA E A INFORMÁTICA" Diniz (2013) e "WEBQUEST: O QUE É E COMO FAZER?” Mathias (2013).

Todos os minicursos tinham a mesma proposta: apresentar o que é uma WQ, suas características e propor a criação de WQs pelos participantes. Os minicursos diferiram apenas nas plataformas utilizadas e discussões, mas serviram de base para um melhor entendimento e apropriação dos mecanismos necessários para se criar uma WQ, e procuraram aproximar os professores da metodologia e consequentemente das TICs.

Ao analisarmos os tópicos e os estudos apresentados anteriormente, consideramos que a WQ está mais próxima de responder às necessidades da 
educação atual e do que exigem as soluções dos problemas atuais, privilegiando vários olhares através do trabalho em grupo, desenvolvendo habilidades cognitivas que vão além de decorar ou reproduzir, transformando informação em conhecimento e dando a esse conhecimento novas utilidades e sentidos, abrindo espaço à criatividade, por vezes reprimidas em sistemas que privilegiam a reprodução e por último devolvendo ao mestre o prazer de também ele criar, ser autor de seu trabalho aproximando as realidades virtuais e físicas na qual o grupo está inserido.

É possível perceber que a WQ embora seja reconhecida e possa ser considerada como metodologia abre espaço para interagir com outros métodos de ensino. Além disso, a maneira como se desenvolve uma WQ apresenta pontos de convergência com as metodologias de jogos na educação, resolução de problemas e modelagem matemática, o que indica que a WQ pode ser um forte aliado na inserção das TICs no ensino de conteúdos matemáticos e mais, mostra-se uma maneira mais dinâmica de relacionar conteúdos e situações do dia a dia.

\section{Porcentagem}

Nesse tópico faremos uma revisão dos estudos realizados sobre o tema porcentagem em Educação Matemática. As pesquisas sobre o tema estão, em sua maioria, atreladas a educação financeira dada a importância do conteúdo para o entendimento de acréscimos e decréscimos percentuais, juros e amortizações, conceitos cada vez mais presentes na vida cotidiana das pessoas ao se realizar uma compra, contrair um empréstimo ou realizar um investimento.

Quanto a resolução de problemas que envolvem porcentagem, Castro Filho

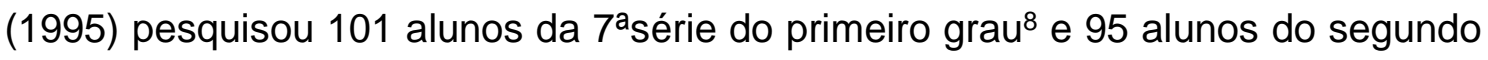

\footnotetext{
${ }^{8}$ A 7ạ série do primeiro grau equivale atualmente ao 8aano do Ensino Fundamental. A nomenclatura foi alterada pelo Projeto de Lei no 144/2005.
} 
grau $^{9}$ de escolas particulares da cidade do Recife. O estudo buscou investigar as estratégias utilizadas pelos alunos na resolução de problemas de porcentagem, que naquele momento, era um conteúdo trabalhado ao final da $6^{\underline{a}}$ série, dentro do tópico de proporcionalidade e tendo como principal método de resolução a regra de três.

Em seu estudo Castro Filho (1995, p.38-40) classificou as estratégias encontradas nos seguintes tipos:

- Composição: O sujeito encontra valores equivalentes a 10\%, 5\%, 2\%, etc. e realiza cálculos (soma, multiplicação, etc.), envolvendo estes valores.

- Valor Unitário: O sujeito encontra o valor equivalente a $1 \%$ da quantidade ou número e, em seguida, realiza cálculos (soma, multiplicação, etc), envolvendo este valor.

- $\quad$ Regra de Três: Sujeito faz uma igualdade entre duas razões.

- Multiplicação seguida de divisão por cem: O sujeito multiplica o valor do problema (quantidade ou número) pela porcentagem dada e, em seguida, divide o resultado por cem.

- Multiplicação por número racional (porcentagem como um operador racional): Sujeito transforma a porcentagem em uma fração decimal, fração não-decimal ou número decimal, e a usa para operar sobre o valor da questão.

- Outras estratégias: Foram agrupadas neste tipo todas as outras estratégias que não puderam ser classificadas no item anterior, como: somente colocar a resposta, somar e subtrair os números envolvidos no problema, tentativa de erro, armar uma equação algébrica diferente de uma regra de três. Em geral, estas estratégias refletiam

\footnotetext{
${ }^{9}$ Segundo grau equivale atualmente a Ensino Médio. Projeto de Lei № 144/2005.
} 
pouca ou nenhuma compreensão das relações envolvidas nos problemas.

Essa classificação proposta por Castro Filho ajudou-nos na análise dos dados relativos aos conhecimentos prévios dos alunos e posteriormente para a análise de uma das tarefas da WQ, fornecendo suporte para entender as estratégias utilizadas pelos alunos bem como seus eventuais erros ou acertos.

Em Bastos (2007) encontramos uma pesquisa realizada com alunos da Educação de Jovens e Adultos (EJA) relacionada à Matemática Financeira com foco nas noções de porcentagem, desconto e acréscimo. O autor constatou com a utilização de dois instrumentos diagnósticos que os alunos não possuíam conhecimentos suficientes sobre os tópicos estudados no que diz respeito a resolver questões do próprio cotidiano. E ao analisar duas coleções de livros didáticos destinados à EJA, aprovados no PNLD 2005, com temas do Ensino Fundamental, Bastos ponderou sobre a necessidade de contextualização adequada ao público específico, o que nem sempre ocorre, por vezes são utilizados recortes dos livros destinados ao Ensino Fundamental regular.

Bastos então propôs uma intervenção com esses alunos e destacou entre as estratégias a serem utilizadas pelos alunos, calcular $10 \%$ e depois promover a composição para outras porcentagens o que auxiliaria os alunos na compreensão do significado de porcentagem mas alertou que essa maneira não é adequada para valores decimais, como $18,4 \%$, nesse caso a sugestão é a utilização da regra de três. Outro ponto importante, principalmente para alunos dessa faixa etária é apropriar-se das tecnologias para realizarem os cálculos, nesse sentido Bastos afirmou ter sido de grande valia para os alunos aprenderem a utilizar a calculadora no cálculo de porcentagens principalmente quando envolvem números mais trabalhosos. 
Em nosso estudo os alunos também utilizaram a calculadora do computador durante a resolução da $W Q$, porém a utilizavam para realizar cálculos de multiplicação e divisão de números decimais e não utilizando diretamente a tecla \% uma vez que se pretendia com a aplicação apresentar um procedimento para calcular a porcentagem mesmo sem o uso da ferramenta. Nas listas de exercícios sobre porcentagens realizadas em sala de aula não foi permitido a utilização de calculadoras.

Vizolli (2006) em sua tese fez uma análise das falas e registros de professores do EJA ao resolverem problemas de proporção-porcentagem. A pesquisa contou com 13 alunos e dois professores do $3^{\circ}$ e $4^{\circ}$ ciclos de EJA no Vale do Itajaí, SC. Nas entrevistas os participantes eram convidados a solucionar problemas propostos pelo pesquisador e registrar as soluções em papel. Vizolli interessou-se em responder como os professores e os alunos escrevem a soluções desses tipos de problemas.

Vizolli procurou valorizar os conhecimentos prévios dos alunos à medida que buscava entender os registros dos mesmos na resolução dos problemas. $O$ pesquisador identificou que para resolver os problemas os participantes apoiaramse em situações do contexto social, não estritas a matemática, como o trabalho, o comércio, o salário; a família e a escola, e situações pertinentes ao conteúdo matemático, taxas percentuais múltiplas de $5 \%$ ou $10 \%$, metade, dobro, decomposição de quantidades, problemas resolvidos anteriormente, reminiscências escolares, estimativa, cálculo mental e, tentativa e erro.

O trabalho de Vizolli nos ajudou a realizar as análises qualitativas na resolução da lista de exercícios e nos reforçou a necessidade de desenvolver atividades contextualizadas, afim de que as mesmas pudessem servir de apoio à resolução de novos problemas propostos. 
Com o intuito de provocar mudanças no posicionamento de alunos da $2^{a}$ série do Ensino Médio referente à Matemática, Dias (2008) propôs a utilização de atividades motivadoras, a participação efetiva dos alunos, uso debates, diálogos e questionamentos. Com essa proposta, realizou um estudo sobre porcentagem com uma turma de alunos oriundos de famílias plantadoras de fumo na região de Camaquã, RS. A pesquisa teve caráter qualitativo e como referencial a etnomatemática e a formação de um sujeito crítico. A pesquisadora buscou com isso utilizar uma metodologia que valorizasse elementos do cotidiano dos alunos respeitando sua realidade cultural e social, atrelando motivação ao pensar crítico uma vez que os alunos ajudaram a pesquisadora a identificar situações a sua volta onde o conceito de porcentagem pudesse ser explorado.

A autora ainda salientou que "sem conhecer a realidade do aluno, as suas vivências, as suas necessidades e até mesmo os seus interesses, não há como motivá-los" (DIAS, 2008, p. 75). Concordamos com a autora e embora não tenhamos ido tão a fundo, procuramos nesse trabalho, de maneira semelhante, buscar elementos que pudessem motivar os alunos na realização da atividade e no desenvolvimento do pensamento crítico através de uma situação que supomos ser motivadora aos alunos por aproximá-los da realidade vivenciada por eles.

Em Figueiredo (2008), a autora investigou a metodologia de resolução de

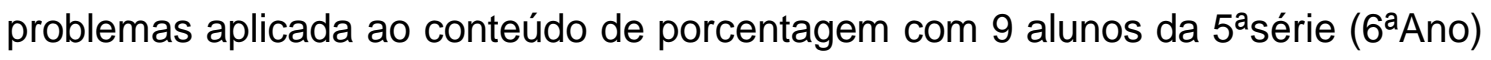
de uma escola municipal em Pantano Grande, RS. Tratou-se de uma pesquisa qualitativa, de caráter exploratório e cunho etnográfico que teve como subsídios teóricos a metodologia de resolução de problemas e a teoria cognitiva de Robbie Case $^{10}$.

\footnotetext{
${ }^{10}$ A Teoria cognitiva de Robbie Case "enfatiza a análise da estrutura e do processo do pensamento do ser humano a partir da resolução de problemas" (Vizolli, 2006, p. 48)
} 
A pesquisadora pôde constatar características de cada processo regulador geral, a saber, a resolução de problemas, a imitação, a exploração e a regulação mútua. Conferiu ainda um destaque especial à regulação mútua que, segundo a autora, "possibilita ao aluno obter conhecimentos através da interação com um ou mais colegas e/ou com o professor além de construir suas próprias operações mentais em consonância com a dos outros e vice-versa." (FIGUEIREDO, 2008, p. 59). Nesse sentido nosso trabalho com WQ se aproximou da pesquisa de Figueiredo uma vez que buscou evidências de melhoria no aprendizado dos alunos como consequência de mudanças nas interações entre os pares, aluno-aluno e alunosprofessor favorecendo o aprendizado de todos os envolvidos.

A pesquisadora questionou também a maneira como o conteúdo de porcentagem vinha sendo desenvolvido nas aulas de matemática, "há professores que trabalham a noção de forma diretiva e apenas através da resolução de exercícios, por ser um método que facilita o seu trabalho e que prende a atenção do aluno na execução" (FIGUEIREDO, 2008, p. 34). Concordamos no que diz respeito à necessidade da utilização de métodos e estratégias mais atuais e diversificados. Como em outros trabalhos já apresentados, fatores como o conhecimento prévio dos alunos, baseado em suas vivências diárias, foi ressaltado como facilitador da compreensão e assimilação.

A porcentagem é uma das noções mais flexíveis no ensino da Matemática, pois permite ser abordada através de uma variedade de temas ligados ao cotidiano. Maia ([s.d], p.10) diz que "todas as situações, que levam o professor a dar um sentido à percentagem, se referem ao domínio financeiro (dinheiro, juros, inflação, salário, etc)". Ao trabalhar com esses temas, o aluno pode se deparar com situações semelhantes às que costuma resolver no seu dia-a-dia, tornando o 
trabalho, com essa noção, atrativo e prazeroso. (FIGUEIREDO, 2008, p.33)

Diante do que foi exposto fica evidente que estas pesquisas levantadas sobre porcentagem na Educação Matemática no Brasil estão, na maioria das vezes, atreladas a Educação Financeira e buscam através dela uma contextualização cada vez mais próxima e particular a do grupo que estuda o conteúdo, procurando assim dar maior significado aos conceitos abordados e propiciar uma nova maneira de se abordar o ensino da disciplina.

A contextualização tenta ressignificar a matemática para o aluno, aproximando-a de sua realidade. Busca-se com isso tirar o status de matéria decoreba e ressaltar essa ciência como uma ferramenta útil para se entender, explicar, planejar e agir de forma consciente diante de uma sociedade cada vez mais complexa, onde muitas variáveis devem ser consideradas e onde entender os conceitos envolvidos no mercado financeiro são indispensáveis ao desenvolvimento da autonomia na vida diária dos educandos.

Outro fator importante ao se realizar uma contextualização adequada é a busca de uma mudança de comportamento dentro da sala de aula através da motivação dos alunos. Os autores citados ressaltam que se os problemas propostos forem instigantes aos educandos há uma maior chance na participação efetiva dos mesmos nas atividades o que pode favorecer a aprendizagem uma vez que deixa de focar nas regras e procedimentos para se chegar a um valor sem sentido prático e passa a se preocupar em capacitar os alunos a resolverem problemas que tem significado dentro de seus contextos econômicos e sociais.

Como as turmas nas quais foi realizada a pesquisa eram do $9^{\circ}$ Ano consideramos ser essa WQ uma atividade de revisão, por outro lado, dado a dificuldade de aprendizagem de boa parte da turma, a maioria apresentava 
conhecimentos insuficientes, principalmente no conteúdo de porcentagem, não podemos considerar como uma simples revisão, para alguns era como um conteúdo novo.

Procurando entender por que alguns alunos não apresentavam o mínimo conhecimento sobre um tema que já havia sido estudado nos deparamos com a pesquisa de Silva, M. M. (2006) na qual a autora realizou um estudo com o objetivo de identificar as possíveis causas dos erros cometidos por alunos do segundo e terceiro ano do ensino médio em questões do ensino fundamental. O estudo foi desenvolvido com 150 alunos, escolhidos aleatoriamente, em escolas públicas (municipal, estadual e federal) e privadas, dos três turnos e de escolas da capital e do interior do estado de Rio Grande do Sul.

Ao realizar a análise sobre a aprendizagem Silva, M. M (2006) leva em consideração duas dimensões que influenciam na aprendizagem, dividindo em questões internas ou externas ao aluno. As questões internas são inerentes a cada aluno e podem ser consideradas para mudanças em fatores externos. Atentaremosnos as questões externas pois essas, por seu caráter social, são passíveis de intervenção por parte do professor e de toda a comunidade escolar.

Quanto aos aspectos externos aos alunos alguns nos chamaram a atenção e foi objetivo da pesquisa melhorar as condições desses aspectos. Silva M. M (2006, p.88-89) descreve entre outros aspectos que são externos aos alunos:

- a falta de diversificação dos materiais didáticos e das estratégias de implementação dos mesmos na sala de aula;

- os conteúdos são compartimentados e estanques, não se comunicam entre si; 
- a desmotivação provocada pela falta de ligação dos conteúdos matemáticos à realidade, que faz com que o aluno se pergunte: 'onde vou aplicar o que hoje estou aprendendo? ';

- a falta de tecnologia adequada ou inexistente (calculadoras, computadores) e software específico como ferramenta disponível para serem utilizados.

Concordamos que esses, e também outros aspectos descritos pela autora, influenciam na formação dos alunos e acreditamos na WQ como uma ferramenta que possibilita mudanças a fim de eliminar, ou pelo menos diminuir, as barreiras que ainda hoje causam insucesso de muitos alunos na aprendizagem de conteúdos matemáticos.

Encontramos nos trabalhos apresentados uma preocupação com a maneira como o conteúdo vem sendo trabalhado, principalmente no ensino fundamental, ainda mais se considerarmos que muitos professores são dependentes da utilização do livro didático. Não pretendemos no momento questionar a importância do livro didático, mas se pensarmos em uma contextualização que seja próxima a realidade do aluno, devemos considerar a dificuldade para um autor de livro conceber situações que contextualizem todas as realidades presente em nosso país de dimensões continentais e inúmeras diferenças culturais. $\mathrm{O}$ que se pretende com essa discussão é salientar a necessidade de criação de atividades pelo docente baseadas no contexto de vida de seus alunos. 


\section{Porcentagem nos livros didáticos do Ensino Fundamental}

Nesse tópico faremos uma breve contextualização sobre como é apresentado o conteúdo de porcentagem em alguns livros didáticos do Ensino Fundamental a partir da análise do Guia do Programa Nacional do Livro Didático de 2014. Além dos estudos apresentados anteriormente somam-se dois artigos sobre o tema publicados na revista BOLEMA: Boletim de Educação Matemática.

O primeiro artigo do BOLEMA de autoria de Ruggiero e Basso (2003), A Matemática no Livro Didático: uma Reflexão Crítica na Perspectiva HistóricoCultural traz uma análise sobre o capítulo de Porcentagem, no volume da 6ª série da coleção escrita por Imenes e Lellis, única coleção de livros com avaliação de "três estrelas", segundo a análise do Programa Nacional do Livro Didático (PNLD, 2014). No segundo artigo, Livro didático, Porcentagem, Proporcionalidade: uma crítica da crítica, Imenes e Lellis (2005), apresentam uma crítica às análises feitas por Ruggiero e Basso.

Teremos como foco ao analisarmos os dois artigos apenas o que é pertinente à apresentação do conteúdo de Porcentagem. Embora as análises tenham sido feitas a mais de uma década a discussão nos dois artigos é interessante, pois nos apresenta as opiniões tanto de especialistas que buscam criticar a maneira como o conteúdo é apresentado no livro didático quanto dos autores do próprio livro, expressando suas concepções ao apresentarem os conteúdos.

É evidente na leitura dos artigos que os autores apresentam concepções diferentes quanto ao status do livro didático, sua utilização, e, principalmente, no que se refere a maneira como é introduzido o conteúdo de Porcentagem no Ensino Fundamental.

Nosso ponto de partida será o próprio conceito de porcentagem que não encontra um consenso entre os matemáticos, em seu artigo $A$ Porcentagem no 
Contexto Escolar: Estratégias utilizadas pelos alunos, Castro Filho (1995) aponta que:

A questão da razão das dificuldades dos alunos com porcentagem continua sem uma resposta definitiva. Davis (1988) afirma que o fato de não haver um consenso entre matemáticos a respeito do conceito de porcentagem deve refletir-se na ausência de sucesso ao tentar ensinar porcentagem para os alunos. A este argumento pode-se acrescentar o fato de que geralmente estes conceitos são ensinados na escola de uma forma desvinculada da realidade do aluno, sem mostrar para que eles são utilizados e também sem aproveitar os conhecimentos que estes mesmos alunos apresentam. (CASTRO FILHO, 1995, p. 34)

Ao analisarem a coleção Ruggiero e Basso (2003) criticam a definição de porcentagem apresentada pelos autores, Imenes e Lellis, o que nos mostra que ainda não existe consenso sobre como definir para os nossos alunos o que é porcentagem:

"A "definição" de porcentagem no Dicionário llustrado também não explica o que significa o símbolo \% e diz que ' $20 \%$ é igual a fração 20/100', quando, a rigor, $20 \%$ é equivalente a razão 20 para $100 . "$ (RUGGIERO; BASSO, 2003, p. 30).

Pois bem, enquanto Imenes e Lellis apresentam a porcentagem como fração, as autoras a relacionam com razão. Nesse sentido Imenes e Lellis (2005) apontam que:

A identificação dos $20 \%$ com uma razão centesimal, mais a atenção que se dá à proporcionalidade no decorrer do artigo, indicam que, para as autoras, os cálculos relativos a porcentagens devam ser realizados 
por meio da igualdade de razões, ou, na denominação mais frequente, pela regra de três. Assim, por exemplo, para obter $20 \%$ de uma quantia Q seria necessário encontrar o valor de x na proporção:

$$
\text { (I) } \frac{x}{Q}=\frac{20 \%}{100 \%} \text {. }
$$

Temos por parte de Imenes e Lellis uma crítica a abordagem tradicional, que apresenta as porcentagens e proporcionalidade em uma sequência considerada lógica. Os autores acreditam que essa abordagem não é adequada ao ensino fundamental e até mesmo do ponto de vista matemático, dado o desenvolvimento histórico da porcentagem. Segundo os autores, a expressão "por cento" surgiu entre os séculos $\mathrm{XV}$ e XVI, e estava associada a contextos que envolviam o comércio. Para eles "a porcentagem tem pouco significado matemático, sendo apenas uma notação indicando a divisão de um número por 100" (IMENES; LELLIS, 2005, p. 16).

Ainda no artigo Imenes e Lellis propuseram uma abordagem alternativa à porcentagem. Dentro da proposta uma das concepções é a "idéia de que a \% é um operador. Isto é, um símbolo que "manda" dividir por 100 e multiplicar por a." (IMENES; LELLIS, 2005, p. 23). A ideia de se entender a porcentagem como um operador tem ligação a forma como as pessoas resolvem os problemas de porcentagem no dia a dia. Encontramos aqui uma valorização das experiências vividas fora do contexto escolar. Nem sempre os caminhos lógicos propostos pelos matemáticos encontram aporte nos conhecimentos prévios ou no mundo das vivências dos alunos.

O fato é que a porcentagem está ligada a vários conteúdos e trata-se de um dos conceitos mais utilizados no dia a dia, seja em cálculo de juros, apresentação de dados, interpretações de gráficos, probabilidade, dados estatísticos e pesquisas dos mais variados assuntos. Ou seja, ao mesmo tempo que o símbolo \% pode representar apenas a divisão de um número por 100, traz consigo a 
responsabilidade de facilitar a informação e os cálculos e está presente no cotidiano de qualquer cidadão.

Para o desenvolvimento do conceito de porcentagem nos vários contextos em que é utilizada é importante que ela esteja articulada a outros conteúdos, e que não seja apenas um capítulo no $6^{\circ}$ Ano do ensino fundamental. Nesse sentido ao analisar o guia do PNLD 2014 tabulei os dados e construí um gráfico que visa contabilizar em quantos capítulos era tratado o conteúdo de porcentagem. Como a fonte de pesquisa foi o PNLD 2014, e não as obras, admite-se que pode haver discordância entre os números aqui apresentados e a realidade encontrada no livro didático, uma vez que foram considerados apenas os capítulos que deixam explícito o estudo da porcentagem.

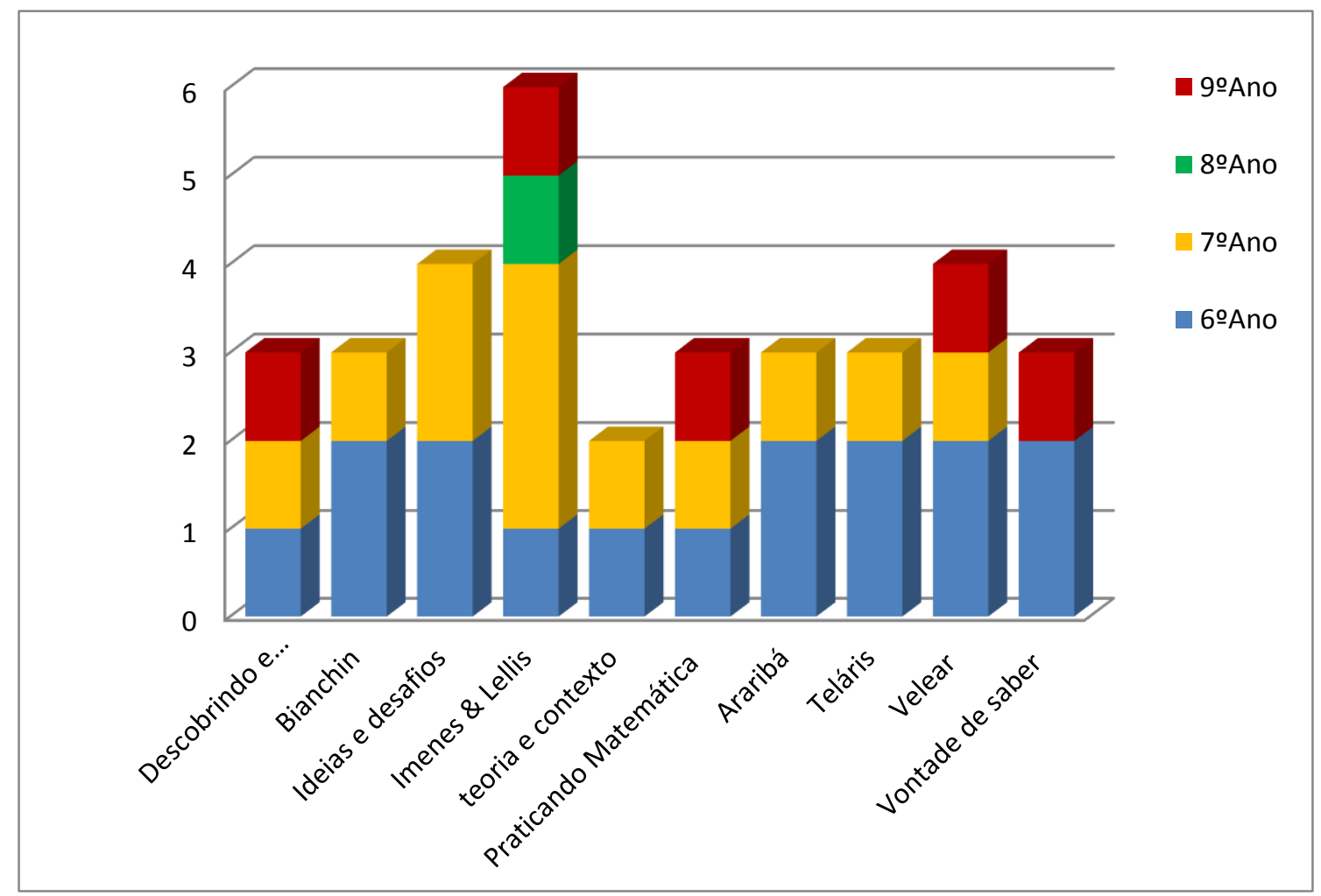

Figura 5 - Número de capítulos sobre Porcentagem por coleção e Ano escolar - PNLD 2014 
Na Figura 5 fica evidente que o conteúdo de porcentagem tem maior concentração no $6^{\circ} A$ no do ensino fundamental. Das 10 coleções analisadas pelo PNLD todas tinham pelo menos um capítulo sobre porcentagem no volume do $6^{\circ}$ Ano e 6 delas apresentavam 2 capítulos sobre o tema. Nos volumes dos $7^{\circ} \mathrm{Ano}$ apenas uma coleção, Vontade do saber, não apresenta nenhum capítulo que faz referência direta a porcentagem.Ganha destaque no volume a coleção Imenes \& Lellis que apresenta o conteúdo em 4 capítulos.

A coleção de Imenes \& Lellis ganha ainda especial destaque no conteúdo de porcentagem uma vez que é a única que aborda de forma explícita os conceitos de porcentagem no volume do 8ำAno, sendo a única a abordar o assunto em todos os anos do ciclo II do ensino fundamental. No total os autores distribuem o conceito por 6 capítulos, sendo a coleção que mais capítulos dedica ao estudo de porcentagens. Nessa coleção a porcentagem está sempre acompanhada de outros conceitos.

Embora ensinar várias maneiras de se calcular porcentagem apresente vantagens para os alunos, preferimos nessa WQ utilizar a abordagem de Multiplicação por número racional, entendendo, como Imenes e Lellis, a porcentagem como um operador.

$\mathrm{Na}$ WQ é utilizado o conteúdo disponível em http://www.somatematica.com.br/fundam/porcent.php que apresenta, de maneira resumida, os frequentes usos da porcentagem em contextos de acréscimos ou reduções em preços. Em seguida relaciona a porcentagem com a razão centesimal, relacionando as suas representações fracionárias, decimais e na forma de porcentagem, conceituando-as como taxas centesimais ou taxas percentuais. Apresenta também a resolução de um problema simples e define: "Porcentagem é o valor obtido ao aplicarmos uma taxa percentual a um determinado valor.", seguido de dois cálculos da porcentagem de um número e dois exercícios resolvidos. 
A estratégia de cálculo apresentada no site assemelha-se a de operador uma vez que sugere a multiplicação seguida da divisão por 100. Por último o site apresenta dicas sobre o fator de multiplicação em um acréscimo ou lucro, e para descontos, com a utilização de números decimais.

Ao definir essa maneira, que é próxima da estratégia de multiplicação seguida de divisão por cem, buscamos valorizar conhecimentos prévios dos alunos que o professor conhecia, pois ele mesmo tinha trabalhado esses conceitos com os alunos. Como os alunos apresentaram um bom rendimento quanto a multiplicação de frações e a divisão por potências de 10, esse método foi o preferido. Ainda que os alunos tivessem aprendido regra de três, para o cálculo de porcentagem o professor preferiu inserir esse método por considerar de fácil memorização e por ser facilmente utilizável para porcentagens de quaisquer números.

Quanto à regra de três não houve ênfase nem mesmo para a resolução dos cálculos de proporcionalidade encontrados na WQ. Para os cálculos que envolviam grandezas proporcionais na WQ foram indicados pelo professor operações de divisão e multiplicação a fim de conceber maior significado se comparado a aplicação repetitiva de uma fórmula. 


\section{Capítulo 2: Delineamento do Estudo}

Segundo diversos autores, dentre eles Appolinário (2006), Gonsalves (2005), Bogdan e Biklen (1994), dificilmente uma pesquisa é apenas quantitativa ou qualitativa. De modo geral há uma mescla entre as duas, em diferentes graus, de acordo com o assunto abordado e o olhar do pesquisador. Um dado estatístico ou numérico, comumente utillizado em pesquisas quantitativas, pode ser analisado ou auxiliar a análise numa abordagem qualitativa.

Para responder a questão central da pesquisa: Em que medida a metodologia WebQuest contribui para a aprendizagem de porcentagem?, foi utilizada uma abordagem predominantemente qualitativa. Como o interesse é avaliar as contribuições da utilização da WQ na aprendizagem de conteúdos matemáticos, fatores como a motivação e empenho dos alunos em realizar as atividades acabam tendo maior importância se comparados a resultados obtidos através de avaliações mecânicas, embora tais comparações tenham sido feitas utilizando análises estatísticas feitas com o programa SPSS (Statistical Package for the Social Sciences).

Embora tenha um caráter qualitativo, aspectos quantitativos estão presentes na análise dos resultados das avaliações diagnósticas e também na lista de exercícios apresentada na WQ.

\section{Pesquisa qualitativa}

Bogdan e Biklen (1994) apresentam cinco características da investigação qualitativa:

1. Na investigação qualitativa a fonte directa de dados é o ambiente natural, constituindo o investigador o instrumento principal. 
O investigador qualitativo precisa entrar em contato com a realidade do grupo estudado, entender o ambiente e suas interações. A observação do grupo realizando as atividades, e as relações estabelecidas entre os membros do grupo são levados em consideração durante a análise dos resultados e, até mesmo, despertam interesse maior do que o produto final da atividade.

Em alguns casos a inserção do pesquisador pode ter influência sobre a realidade pesquisada e isso deve ser levado em conta.

\section{A investigação qualitativa é descritiva}

$\mathrm{Na}$ investigação qualitativa a maneira como os dados são apresentados e que dados são considerados assumem uma grande importância. Por exemplo, quanto ao laboratório de informática é importante sabermos quantos eram os computadores disponíveis, mas é também importante informar sobre a maneira como estavam dispostos, se auxiliavam ou dificultavam o trabalho, se havia espaço para que o aluno utilizasse outros materiais manuais simultaneamente às pesquisas, entre outros fatores.

$\mathrm{Na}$ pesquisa qualitativa um fato nunca deve passar desapercebido ou encarado como insignificante, às vezes se nos atentarmos a pequenos gestos podemos tirar grandes conclusões.

3. Os investigadores qualitativos interessam-se mais pelo processo do que pelos resultados ou produtos

Não quer dizer que os resultados tenham pouca importância mas numa abordagem qualitativa, entender o processo que levou aos resultados é fundamental para o entendimento da questão. Durante o desenvolvimento da pesquisa e das atividades realizadas pelos participantes, muito do que está envolvido no processo desperta interesse e pode ter significados que aumentam a compreensão e auxiliam numa melhor análise até mesmo dos resultados. 
Por exemplo, mais importante do que obter um bom resultado é entender como esse resultado foi construído, em que pilares está apoiado.

4. Os investigadores qualitativos tendem a analisar os seus dados de forma indutiva

Na pesquisa qualitativa, de maneira geral, não se busca confirmar ou não uma hipótese previamente pensada, as questões fundamentais surgem do contato com o grupo pesquisado e dos dados recolhidos. A própria formulação da questão central pode mudar e muitas vezes não apresenta espaço para se confirmar ou não, busca-se entender um processo, como no caso dessa dissertação.

5. O significado é de importância vital na abordagem qualitativa

Nesse sentido, o pesquisador procura entender como as diferentes pessoas do grupo dão significados e sentidos as suas ações e interações. Nas pesquisas em educação essa perspectiva é bastante utilizada para entender como o aluno percebe sua relação com o tema, os colegas ou o professor.

Dentre as classificações de pesquisas qualitativas que buscam descrever a realidade ou problema encontrado, a pesquisa-ação tem, também, como objetivo, através de análises prévias, observações e atividades intencionais, promover uma mudança nas práticas até então realizadas pelo grupo estudado.

\section{Pesquisa-Ação}

A Pesquisa-Ação é uma pesquisa feita através da análise da realidade a ser transformada e de reflexões sobre as práticas realizadas por um determinado grupo. Segundo Thiollent (2007), além da participação, busca uma intervenção por meio de uma ação planejada de caráter social, educacional, técnico ou outro. 
No ambiente escolar a pesquisa-ação pode ser de grande utilidade auxiliando professores e gestores nas mudanças necessárias em suas práticas diárias visando a melhoria na qualidade do ensino. "No contexto da construção ou da reconstrução do sistema de ensino, não basta descrever ou avaliar. Precisamos produzir ideias que antecipem o real ou que delineiem um ideal". (THIOLLENT, 2007, p. 80-81).

Uma maneira bastante interessante de apresentar a metodologia de pesquisa-ação é a da Figura 6, que foi proposta por Pereira e Zeichner (2008, p. 44).

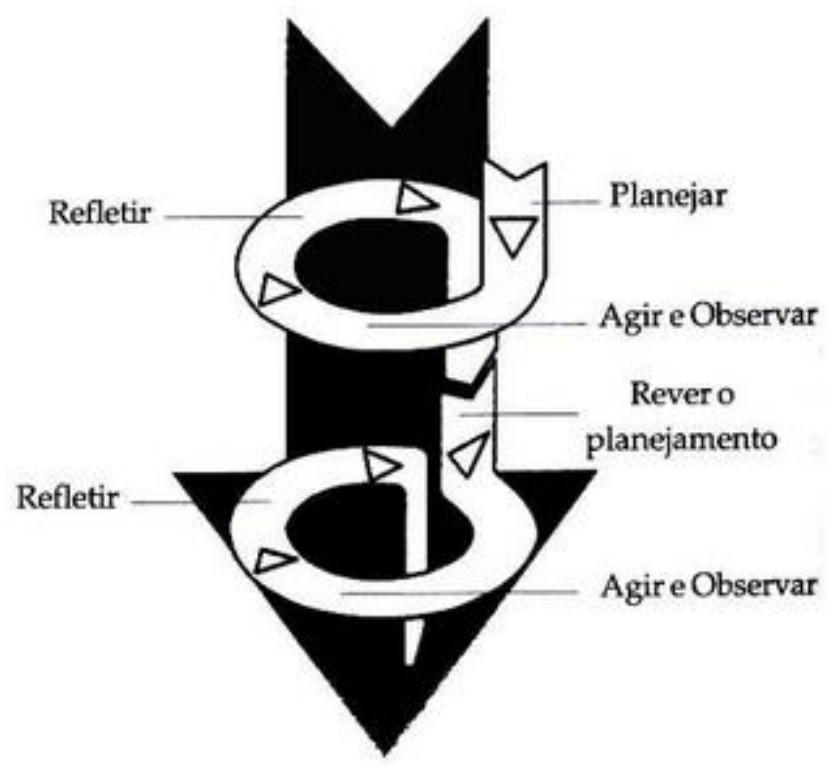

Figura 6 - Espiral de ciclos auto-reflexivos na pesquisa-ação

Nota-se na Figura 6 um ciclo em espiral que traduz o trabalho do pesquisador em uma pesquisa-ação com a sequência de planejar, refletir, agir e observar, rever o planejamento, refletir novamente, agir e observar, e assim por diante, em ciclos que visam mudanças intencionais nas ações realizadas, baseadas nas observações do pesquisador, propondo melhorias nas atividades. 
Note que agir e observar estão sempre associados uma vez que o observador é também um participante, e em alguns casos, como nessa pesquisa, também objeto de análise.

A presente pesquisa caracteriza-se como pesquisa-ação uma vez que 0 pesquisador é também professor do grupo e tem como um dos objetivos ressignificar as aulas de matemática e influenciar a maneira como o grupo se relaciona com os conteúdos matemáticos.

Com a utilização de uma WQ o professor buscou motivar os alunos e colocálos em ação na construção de seus saberes, alterando o foco da aula e os papéis tradicionalmente assumidos por professor e alunos.

Sendo assim a intenção foi despertar nos alunos o interesse pela matemática através de situações que os levassem a refletir sobre o cotidiano, de maneira ativa para que desenvolvessem segurança e autonomia quanto a utilização de métodos e modelos matemáticos para resolver problemas diários, demonstrando a importância do conhecimento matemático, e ainda favorecer, através da metodologia de WQ, a inserção das TICs e a interdisciplinariedade nas aulas de matemática.

Para responder ao problema de pesquisa "em que medida a metodologia de WebQuest contribui para a aprendizagem de porcentagem?" o estudo concentrou-se nos seguintes objetivos:

- Identificar fatores no uso da WebQuest que podem contribuir para a aprendizagem de porcentagem;

- Investigar se há melhora na resolução de problemas que envolvem porcentagem;

- Analisar a aplicação da metodologia de WebQuest nas aulas de Matemática em uma escola pública do interior do Estado de São Paulo. 


\section{Lócus da pesquisa}

A pesquisa foi realizada em uma escola pública estadual do interior do estado de São Paulo. Escolher a escola onde o professor-pesquisador lecionava foi uma decisão visando facilidade de acesso para a pesquisa e um conhecimento prévio sobre como se davam as interações entre professor-alunos e entre os alunos em sala de aula, em aulas tradicionais e até mesmo em atividades com pesquisas ou assistindo vídeos no laboratório de informática.

Além disso, a própria metodologia utilizada, pesquisa-ação, sugere alterar de maneira consciente e orientada os contextos estudados, nesse caso em um ambiente escolar é importante um contato mais duradouro com os alunos, identificando de maneira mais expressiva suas mudanças de motivação, comportamento e participação durante as aulas.

Quanto a cidade, ela possuia uma população de pouco mais de 12 mil habitantes, em sua maioria moradores da área urbana porém com características rurais devido, principalmente, às atividades agropecuárias, base da economia local, como a plantação de cana-de-açúcar, criação de animais e plantações de café, cereais, algodão e laranja.

A escola na época da pesquisa era a única escola estadual do município e atuava nos anos finais do ensino fundamental durante a tarde, no ensino médio pela manhã e à noite e, na Educação de Jovens e Adultos (EJA).

Embora a escola esteja localizada na região central da cidade recebe alunos de outros bairros e até mesmo de fazendas ou sítios localizados nas proximidades. A prefeitura oferece transporte gratuito a todos que desejam estudar garantindo 0 acesso a escola.

O prédio não apresentava um bom estado de conservação, principalmente por ser uma construção antiga, ainda mais se levarmos em conta que em 2011 foi 
realizada uma pintura interna e externa. Das 9 salas de aula, algumas apresentavam na ocasião da pesquisa a porta quebrada, em quase todas havia pelo menos um vidro quebrado e em outra o ventilador estava quebrado e assim permaneceu até o final do ano letivo de 2013.

Em todas as salas, cadeiras, mesas, paredes e lousas estavam pichados. Dependendo do horário e da posição do sol em algumas salas o ambiente não era satisfatório para se realizar uma aula, pois com a falta de ventilação algumas salas ficavam quentes e abafadas. As cortinas além de pichadas eram rasgadas pelos alunos ou apresentavam pontos de mofo.

A biblioteca era pequena, mas comportava um número considerável de livros em seu acervo e contava com uma bibliotecária que atendia em períodos prédeterminados. Devido ao tamanho da biblioteca e a falta de mesas e cadeiras no local, não era possível a permanência de grandes grupos ficando seu ambiente destinado a atividades de recuperação ou do projeto sala de leitura. Além dos livros, estavam disponíveis para a comunidade escolar filmes e documentários e seus empréstimos eram controlados pelas coordenadoras pedagógicas.

A escola possuia um amplo pátio, e uma cozinha/cantina onde era servida a merenda escolar com mesas e cadeiras, porém não em número suficiente para atender a todos os alunos. A quadra poliesportiva era coberta, e atrás da mesma existia uma quadra de vôlei não coberta utilizada somente nas aulas de educação física ou no projeto "Escola da família" nos finais de semana.

Há alguns anos não se realizava nenhum tipo de torneio que envolvia os alunos com a justificativa de que os mesmos geravam muitos conflitos. Em minha opinião, conflitos geram a possibilidade de uma conversa franca e podem, se bem trabalhados servir para educar os alunos quanto ao respeito com os colegas, os limites de cada um e sobre o comportamento adequado durante um evento social. 
Embora a conservação não fosse a melhor possível, a estrutura física do prédio comportava razoavelmente bem as turmas do ensino fundamental no período da tarde e o laboratório de informática apresentava a maior parte dos computadores em uso.

O laboratório possuia ao todo 16 computadores conectados a Internet, sendo um deles exclusivo para o uso do monitor, e outro para o uso do retrojetor. Durante o desenvolvimento do estudo piloto em 2012, dos 14 computadores disponíveis, apenas 2 apresentavam mau funcionamento; em 2013, durante a pesquisa, todos estavam funcionando adequadamente, sendo limitados principalmente, pela velocidade da Internet, que ainda não era a mais indicada.

O laboratório apresentava melhores condições de conservação se comparado ao restante da estrutura física da escola. Era possível utilizá-lo sem maiores complicações embora faltasse, em minha opinião, uma mesa maior para que os alunos pudessem manipular outros materiais em conjunto com os computadores. Considero-o um bom espaço se comparado aos laboratórios de outras escolas nas quais trabalhei, porém sei que para as turmas da manhã que eram maiores, o laboratório apresentava número insuficiente de computadores.

Consideraria melhor se na disposição dos computadores todos ficassem virados para o mesmo lado, o do retro projetor ligado ao computador utilizado, geralmente, pelos professores, pois facilitaria caso o professor necessitasse mostrar aos alunos como realizar um determinado procedimento.

A Figura 7 apresenta um esboço do laboratório de informática para facilitar o entendimento do leitor. O ar-condicionado foi instalado no começo de 2013. Embaixo da mesa (17) existe uma caixa de som onde é reproduzido o áudio dos vídeos transmitidos pelo projetor. A sala é espaçosa e permite a fácil locomoção pelos corredores, exceto no corredor dos computadores 12 a 14 . 


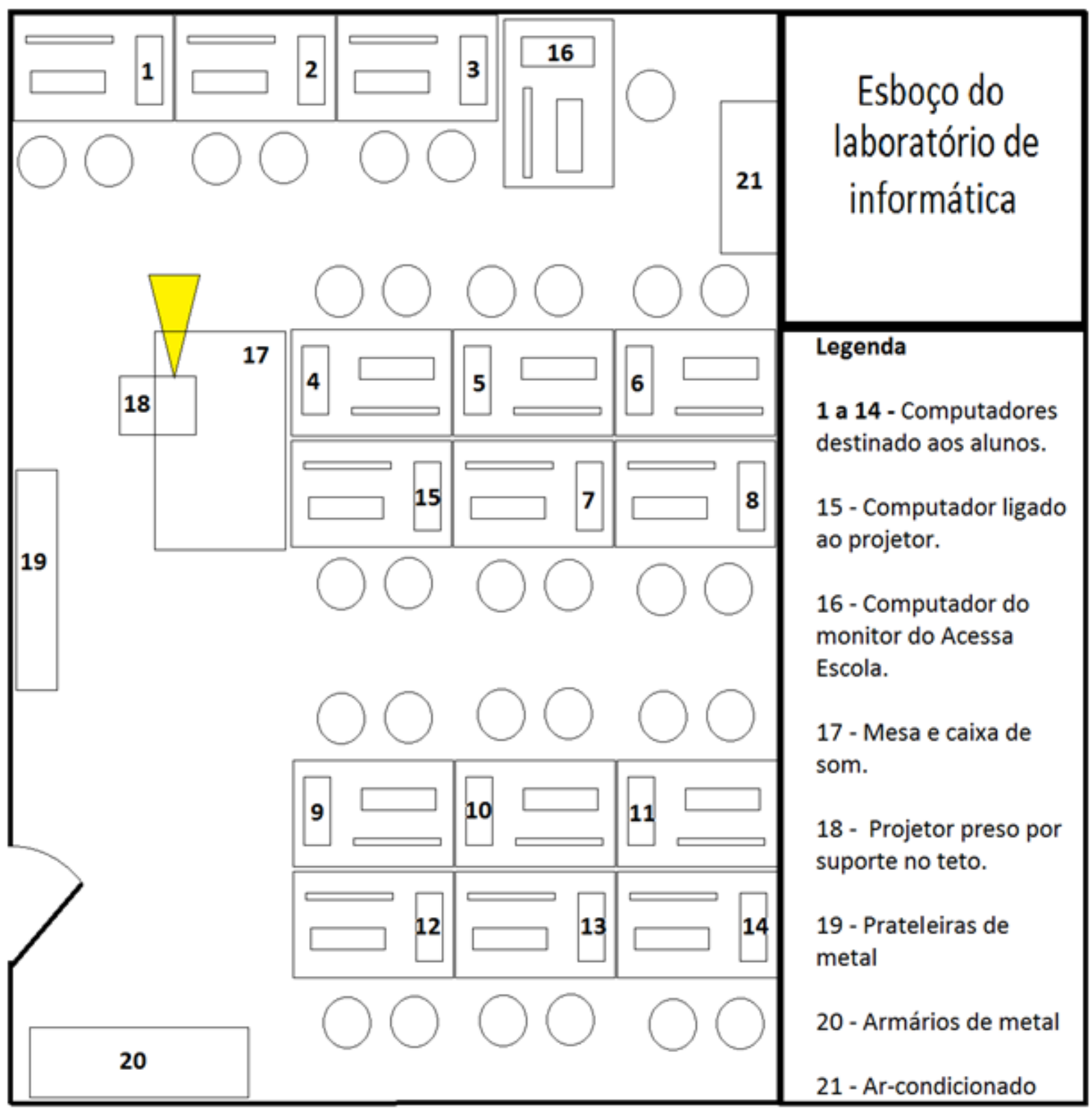

Figura 7- Croqui do laboratório de informática - Fonte própria.

Além dos computadores localizados na sala de informática, a escola possuía mais um computador na diretoria, dois na secretaria, dois notebooks na sala de coordenação e um desktop na sala dos professores, todos conectados a Internet e com impressoras. Os notebooks da coordenação poderiam, se agendados previamente, serem utilizados junto a um projetor e uma caixa de som, pelos professores em sala de aula, sendo a instalação de responsabilidade dos monitores 
do programa Acessa Escola ${ }^{11}$. As impressoras da sala dos professores quase sempre se encontravam sem tinta, o que impossibilitava, muitas vezes, a utilização de material ou impressão de provas.

O planejamento escolar acontecia no início do ano letivo e um replanejamento era realizado às vésperas do início do segundo semestre, em datas definidas pela Secretaria de Educação do Estado de São Paulo. O foco era o desenvolvimento de habilidades e competências objetivando a melhoria dos índices em avaliações externas como o Sistema de Avaliação do Rendimento Escolar do Estado de São Paulo - SARESP e Prova Brasil. Para isso eram realizadas avaliações diagnósticas e ações planejadas a partir das mesmas.

\section{Participantes}

Foram pesquisados 47 alunos de duas oitavas séries (nono ano) do ensino fundamental, $8^{\mathrm{a}} \mathrm{A}\left(9^{\circ} \mathrm{A}\right)$ e $8^{\mathrm{a}} \mathrm{B}\left(9^{\circ} \mathrm{B}\right)$ de uma escola estadual do interior do Estado de São Paulo.

As turmas foram escolhidas por serem os únicos nonos anos da escola e por serem turmas onde o pesquisador desempenhava o papel de professor favorecendo as observações no que diz respeito a inserção do pesquisador no ambiente de pesquisa, no contato com os alunos, na avaliação da aprendizagem, nas mudanças de comportamento, motivação e participação dos alunos durante a atividade.

Desta forma, essa pesquisa utiliza uma amostragem por acessibilidade ou por conveniência na qual "o pesquisador seleciona os elementos a que tem acesso, admitindo que estes possam, de alguma forma, representar o universo."(Gil, 1999,

\footnotetext{
${ }^{11}$ Acessa Escola: Programa do Governo do estado de São Paulo que visa a inclusão digital de toda a comunidade escolar.
} 
p. 104). Trata-se de uma amostragem que não apresenta rigor estatístico utilizada em estudos exploratórios ou qualitativos como neste estudo.

Foi importante para a análise dos dados ter como referência 0 comportamento dos mesmos alunos quando em sala de aulas convencionais e até mesmo em atividades anteriormente realizadas no laboratório de informática mas sem a metodologia da WebQuest.

Comecei a trabalhar com esses alunos no ano letivo de 2011, quando cursavam o sétimo ano do Ensino Fundamental e fui surpreendido pelo abismo entre os conteúdos presentes nos Cadernos do Aluno e Professor, material com situações de aprendizagem envolvendo conteúdos matemáticos, produzido pela Secretária da Educação do Estado de São Paulo, e os conhecimentos prévios dos alunos que ainda não dominavam as quatro operações com números inteiros e pouco entendiam sobre o significado e as operações com números fracionários ou decimais.

A $8^{\mathrm{a}} \mathrm{A}\left(9^{\circ} \mathrm{A}\right)$ possuía 22 alunos e a $8^{\mathrm{a}} \mathrm{B}\left(9^{\circ} \mathrm{B}\right), 26$ alunos, desses somente um aluno da $8^{\underline{a}} \mathrm{~A}\left(9^{\circ} \mathrm{A}\right)$ não apareceu durante dia algum de aplicação pois apresentava problemas de saúde. O número de alunos por turma era satisfatório, o espaço físico da sala era bem grande e todos podiam sentar-se a uma distância confortável uns dos outros, o mesmo acontecia no laboratório de informática onde foi possível acomodá-los com conforto, mas não individualmente por computador. Somente durante um dia de aplicação uma dupla ficou impedida de começar as atividades pois um computador apresentava problemas, e não havia um computador reserva, porém em poucos minutos a situação foi normalizada não resultando em nenhum prejuízo maior causado por falta de equipamento. 


\section{O Estudo Piloto}

No ano de 2012, foi realizado um estudo piloto que visava aproximar o professor/pesquisador da metodologia WQ.

Era necessário um contato prático com a metodologia para que pudesse identificar, para além do que havia encontrado na literatura, as possíveis dificuldades tecnológicas, avaliar o seu desempenho e seu papel dentro da metodologia.

Outros fatores importantes eram identificar as possíveis dificuldades dos alunos bem como avaliar se o nível da WQ estava compatível com os conhecimentos prévios da série em questão.

Enfim, fornecer subsídios para que, se necessário, realizar modificações afim de que a aplicação pudesse ser melhor planejada e executada, produzindo dados para a análise da utilização da metodologia que pudessem ser de melhor qualidade.

Para a aplicação da $W Q$ não foi necessário realizar nenhum trabalho burocrático no sentido de obter autorizações.

Com o ano letivo em andamento foi conversado, durante a ATPC (aula de trabalho pedagógico coletivo), com a coordenadora pedagógica, que seria utilizada uma nova metodologia de ensino na tentativa de rever/apresentar os conteúdos por meio da $W Q$, e que essas aulas seriam parte integrante de um estudo piloto que visava oferecer subsídios para uma pesquisa que seria realizada no ano seguinte com vistas a produção de uma dissertação de mestrado.

A coordenadora foi favorável a realização das aulas e da pesquisa, mas solicitou que a realização fosse mais para o final do ano letivo em 2012.

O estudo piloto foi realizado nos meses de outubro e novembro, de 2012, em $5 \mathrm{~h}$-aula por turma, no laboratório de informática da escola. Para o uso do laboratório bastava marcar o horário e acomodar os alunos em seus computadores. Durante a 
aplicação da WQ os conteúdos envolvidos na mesma não foram trabalhados em sala de aula, onde eram desenvolvidas outras atividades de revisão relacionadas a outros conteúdos do SARESP.

A atividade foi pensada para ser realizada em duplas mas, por número ímpar de participantes ou escolha pessoal, alguns alunos a realizaram individualmente. Antes dos alunos iniciarem foi exibido o curta metragem BMW Vermelho e o professor buscou motivar e despertar a curiosidade dos com a pergunta final da introdução da WQ "Será que é mesmo vantajoso ganhar um BMW nas condições do curta-metragem?". No curta-metragem uma família de baixa renda ganha um BMW em um sorteio mas não pode vendê-lo pelo prazo mínimo de um ano.

Pensando nas dificuldades da família de baixa renda premiada com um BMW Vermelho, quase um cavalo de tróia, que vive em um bairro periférico, como o dos próprios alunos, uma realidade próxima a deles, uma arquitetura e uma organização social mais próximas do seu dia a dia, seria mesmo vantajoso?

Durante a leitura da WQ com os alunos para fazer o primeiro contato, procurou-se ressaltar a questão do IPVA - imposto cobrado para que possa circular com um veículo automotor pelas ruas. Discutimos como e onde esse imposto deve ser aplicado e se de fato os orgãos públicos vem fazendo bom uso dessa arrecadação.

A imagem que aparece na aba "Tarefa" mostra um congestionamento e sugere pensar em diversas coisas: a quantidade de carros nas ruas, consequentemente, o volume dessa arrecadação, a poluição ambiental, o transporte coletivo entre outros temas que favorecem o desenvolver do pensamento crítico pelo aluno. 
Após a explicação da situação de aprendizagem e de como deveriam proceder para realizar as atividades, o professor pediu para que abrissem a tabela que havia sido previamente compartilhada em seus e-mails e iniciassem as atividades.

Enquanto um grupo de alunos começou a ler a aba "Processo" e a navegar pelos links propostos pelo professor e a partir dos dados encontrados preencheram a tabela, muitos estavam olhando para a tabela e para alguma página relacionada na WQ mas não desenvolviam o trabalho.

Durante a aplicação o professor fez como fazia em sala de aula e preencheu, com cada dupla que estava sem dar início ao trabalho, uma parte da tabela. Essa atitude, a primeira vista pode parecer o certo uma vez que mesmo alunos apáticos em aula agora buscam o auxilio do docente por estarem motivados. Mas o que foi possível perceber é que isso fez com que os alunos buscassem o professor o tempo todo para que os ajudassem, fizesse junto, ou para certificarem-se que estavam no caminho certo, o que por sua vez representava um problema dentro de uma metodologia que busca desenvolver a autonomia do educando.

Nesse momento reflexões levaram a dúvidas quanto ao papel do professor dentro da metodologia, uma vez que buscava-se através da mesma explorar mais do que o conteúdo. A atitude do professor teria que ser diferente, ou simplesmente reproduziria o formato das aulas tradicionais em outro ambiente, sem mudança no foco, era preciso ativar o movimento do aluno no caminho da aprendizagem.

Com muitos alunos motivados e somente um professor para atendê-los os problemas começaram a surgir.

O aluno A22b2012 ${ }^{12}$ da 8르 de 2012 apresentava um déficit de aprendizagem grande em relação aos demais alunos da sala o que o levava a não participar das

\footnotetext{
12 Os participantes foram codificados com a letra A (aluno), no, turma (a ou b) e o ano de realização da coleta de dados. Exemplo: A22b2012 é o aluno número 22 da turma b no ano de 2012.
} 
aulas mesmo quando estimulado pelo professor. Em algumas oportunidades o professor se dispunha a ajudá-lo na realização dos exercícios em sala de aula e o aluno ainda assim recusava-se a participar. As observações diárias evidenciavam que o aluno apresentava uma baixa auto estima e certa insegurança, o que o levavam a desistir antes mesmo de tentar, possivelmente pelo medo do fracasso.

Foi realmente surpreendente ver a maneira como a atitude do aluno mudou quando se deparou com a situação da WQ. O aluno que se recusava a realizar qualquer atividade era o recordista em requisitar o professor. Houve inclusive uma discussão entre ele e a aluna A3b2012 de sua turma, uma aluna que apresentava dificuldades de concentração e comportamento porém conseguia resultados medianos quando estudava para as avaliações.

A relação com a aluna era dificultada por sua impaciência, sempre que necessitava de ajuda e o professor não podia ajudá-la imediatamente, recusava a ajuda para realizar a atividade depois. A aluna também demonstrou interesse pela atividade e devido a pouca autonomia dos alunos em questão, foi grande o número de chamadas dos dois alunos que eram de duplas diferentes, a cobrança pela presença do professor levou os alunos a uma discussão que foi rapidamente contornada pelo professor explicando aos dois e aos demais, que precisavam focar em realizar a atividade somente seguindo as instruções e a partir do terceiro dia foi notável como estavam mais independentes.

Nesse momento ficou ainda mais claro para o professor/pesquisador que deveria mudar o seu comportamento quanto a realizar com os alunos parte da tarefa, ou ficar acompanhando por muito tempo o trabalho de um aluno pois seria impossível estar tão próximo de todos, ainda assim era necessário observar o trabalho para perceber como os alunos estavam interagindo entre eles, dentro e fora de suas duplas, e também com a atividade. 
Com a turma de 2013 o professor/pesquisador, já sabendo das dificuldades dos alunos, pôde ser mais claro nas explicações sobre como realizar as atividades e embora alguns ainda demonstrassem insegurança, eram incentivados a relerem a instrução com mais atenção e a discutirem com o colega o que deveriam fazer em cada uma das atividades da WQ.

Foi explicado que ler, interpretar e seguir as orientações presentes na aba "Processo" faziam parte do aprendizado deles pois também era objetivo da atividade que eles melhorassem a leitura, a interpretação e a produção de texto, por isso deveriam escrever um parecer sobre a melhor escolha. Além disso era intuito da metodologia desenvolver neles a capacidade de coletar, organizar e através dos cálculos tomarem decisões em outras situações do seu dia a dia, onde não teriam a ajuda do professor.

Essa primeira conversa foi muito importante pois a partir desse momento a maior parte das duplas procurou se empenhar mais para realizar a tarefa sem 0 auxilio do professor mas ainda assim, sendo orientados pelo professor no sentido da importância da organização dos dados, das aproximações das casas decimais, algo diretamente ligado ao conteúdo e reflexões sobre os gastos de cada veículo. 0 professor transitava pela sala e avaliava continuamente o trabalho das duplas, intervindo quando julgava necessário.

Com isso o professor conseguiu ter mais tempo e aproveitar a motivação dos alunos com dificuldades, dispendendo maior atenção aos que mais necessitavam. É interessante notar que a situação motivava os alunos e mesmo alguns que apresentavam dificuldades ou apatia em sala de aula, motivados dispunham-se a tentar realizar sozinhos e quando não conseguiam procuravam o professor para auxiliá-los. 
Algumas duplas trocaram dados (colaram) tanto na atividade realizada no computador quanto na lista de exercícios que podiam levar para casa e realizar em dupla. Percebendo isso a lista final passou a ser individual e somente poderia ser realizada em sala de aula, fornecendo outro instrumento de análise, a comparação dos resultados obtidos antes e depois da realização da WQ.

Embora todas as duplas tenham realizado a mesma atividade algumas configurações nos navegadores da Internet mudavam a quantidade de dias úteis podendo ser 254 ou 252, e o google mapas apresenta diferença na quilometragem das viagens dependendo da ordem em que eram escolhidas as cidades, sendo de 40,6 km para um trajeto e de $47 \mathrm{~km}$ para o outro. Isso levou a quatro combinações diferentes de gabarito e ajudou a evidenciar quando as duplas utilizavam dados das tabelas de colegas para preencherem as suas. Por exemplo, alguns alunos apresentavam 254 dias utéis na tabela mas o valor calculado para o gasto total estava correto para o valor de 252 dias úteis evidenciando que esses alunos poderiam ter conseguido o valor com outra dupla.

Muitos alunos apresentaram dificuldades na escrita do parecer e muitos dos textos ficaram mal formulados e com argumentações óbvias, que faziam referência direta aos dados calculados na Tabela. Nesse sentido, cabe aqui salientar que era objetivo do professor, a partir do segundo ano de aplicação, promover a interdisciplinaridade em um trabalho conjunto com outros professores, no caso Português para auxiliar na escrita e correção dos pareceres e Ciências para contextualizar e explorar melhor conteúdos relacionados ao consumo de combustível e a poluição.

Porém, muitas barreiras foram encontradas como a falta de conhecimento sobre a metodologia e falta de tempo para que os professores pudessem aprender sobre a mesma. No caso de ciência a professora não demonstrou interesse em 
realizar o trabalho, acredito que devido às dificuldades e até mesmo receio em utilizar computadores de maneira inovadora.

A professora de português demonstrou boa vontade, mas com poucos e corridos encontros semanais não foi possível desenvolver o trabalho em conjunto.

Mesmo sem desenvolver a atividade com a professora de português 0 professor pôde contar com alguns conselhos dessa e de outra professora que estava no cargo de coordenadora que o ajudaram a explicar para os alunos como escrever um parecer. Também ajudaram a estabelecer melhores critérios para a avaliação dos textos.

Embora não tenham sido descontados pontos para erros ortográficos ou de concordância, o professor destacava tais erros nos textos a fim de que os alunos pudessem perceber o que haviam errado, e algumas vezes era sugerido, abaixo do texto, juntamente à nota naquela atividade, que o aluno prestasse atenção nos erros cometidos. Um exemplo disso pode ser notado na passagem escrita pelos alunos A21b2012 e A22b2012, a seguir:

Eu escolheria um carro popular porque e mais económico já a bmw gastaria o dobro do carro popular mais o menos 63,000, $\underline{\mathrm{e}}$ as parcelas é mais baratas e não gasta muito gasolina esobra mais dinheiro para gastar com a familia e um carro poplar seme novo não poluia muito o ar, não é presiso comprar pessas cara quando o carro quebrar e a bmw as pesas são muito caras e dificil de achar, mas preferia transporte coletivo. Em dia cada veiculos leva mais o menos duas pessoas bem menos que o onibus pode levar com 30 pessoas céntadas,compensa mais o transporte coletivo porque gasta menos dinheiro, acredito que 0 ideal para nossa cidade é um transporte rapido e ficas. 
Podemos notar no texto escrito pela dupla muitos erros ortográficos, de concordância e de digitação, além da falta de coesão e coerência entre as ideias, mas como ponto positivos pudemos perceber que os alunos se preocuparam em salientar a poluição do ar e o transporte coletivo, ideias secundárias da situação porém não menos importantes ou formativas, pelo contrário são temas imprescindíveis quando se pensa em uma educação cidadã e tem-se como pretensão desenvolver o senso crítico dos alunos.

Por outro lado, outros textos foram ao encontro do que se esperava da situação de aprendizagem. As alunas A5a2012 e A6a2012 colocaram-se na posição de empresárias quando as mesmas disseram durante a atividade e começaram o texto com a frase "Querido amigo estou aqui na minha empresa e pelos os meus cálculos dá para perceber que para você o melhor seria que ficasse com um carro popular(...)". Essa passagem nos evidencia que as alunas usaram a criatividade para assumir personagens que não foram previamente previstos mas que parecem tê-las estimulado na resolução do problema.

Durante a correção e a posterior análise da lista de exercícios (Tarefa 4), foi possível perceber que para se ter uma evidência da contribuição das WQ no ensino de conteúdos matemáticos era necessário medir o grau de conhecimentos prévios individuais sobre os temas abordados de maneira qualitativa pois, até então, o que indicava o mal desempenho dos alunos era o simulado do SARESP desenvolvido e aplicado pela coordenação da escola, uma prova objetiva que indicava somente 0 erro ou acerto da questão mas não identificava onde estavam as dificuldades de cada aluno.

Além disso, como os alunos resolviam a lista em casa desconfiava-se que alguns alunos tenham copiado ou recebido ajuda de algum colega, o que poderia comprometer os dados provenientes de tal tarefa, os tornando pouco confiáveis. 
Novamente o estudo piloto indicou um ponto que precisava ser alterado, era necessário que o professor pudesse observar enquanto os alunos resolviam a lista e pudesse ter uma base para comparar com o que ele havia aprendido através da WQ. Pensando nisso, no ano de 2013, os alunos resolveram a lista de exercícios antes de realizar a atividade na WQ e depois, a mesma lista, como tarefa da WQ. Com isso o professor/pesquisador coletou um conjunto de dados mais significativos que poderiam ser analisados qualitativamente e quantitativamente.

Quanto à indisciplina dos alunos durante o desenvolvimento da WQ foi possível notar que já no estudo piloto houve melhora no comportamento da turma como um todo tornando o ambiente de aprendizagem mais agradável e propício aos estudos. O único episódio de indisciplina durante o estudo piloto foi do aluno A8b2012 que realizava a atividade com o aluno A7b2012 da mesma turma. Devido a problemas familiares, A8b2012 sempre apresentou comportamento agressivo e era visto como um líder pelos outros alunos e alguns professores.

Durante o terceiro dia de atividades A8b2012 se recusava a auxiliar A7b2012 na realização das tarefas e quando questionado pelo professor se revoltou e começou a agredir verbalmente o professor/pesquisar com palavrões e ameaças. 0 professor conduziu o aluno para fora do laboratório, porém não havia nenhum membro da direção que pudesse conversar com o aluno, então o mesmo ficou sob a supervisão das inspetoras enquanto a aula continuou com os demais alunos.

No próximo dia de atividade A8b2012 voltou ao laboratório e auxiliou A7b2012 a realizar o restante das atividades no laboratório e também a lista de exercícios sem problemas de indisciplina.

A mudança de comportamento não foi percebida como algo de especial visto que constantemente acontecia a mesma coisa em sala de aula, o aluno apresentava 
comportamento agressivo e nos dias seguintes procurava se comportar bem pois mantinha uma boa relação com o professor/pesquisador em questão.

A realização do estudo piloto foi de grande valia para a prática docente do professor o que certamente refletiu nos resultados e análises da pesquisa uma vez que mais confiante e preparado para desenvolver as atividades com os alunos, colocando-se como um mediador entre o conteúdo, a situação de aprendizagem e os alunos, motivando os alunos a realizarem as atividades propostas, auxiliando na escrita dos pareceres e propondo reflexões sobre as relações entre consumo, poluição, leis e transporte público, conseguiu-se uma atividade sólida e melhor aplicada em 2013, e obtendo como resposta dados mais confiáveis favorecendo a análise que será apresentada no próximo capítulo.

Quanto aos resultados obtidos pelos estudantes, como exposto anteriormente não houve uma preocupação única com as notas e resultados mas as mesmas não deixaram de representar, também, um subsídio para a análise quanto a eficácia do método.

\section{A pesquisa}

Durante o planejamento para o ano letivo de 2013 foi apresentada a toda a comunidade de professores e coordenadores da escola o trabalho que vinha sendo desenvolvido e foi feito um convite para que outros professores integrassem o projeto da WQ, contudo os professores que demonstraram interesse eram do Ensino Médio, logo não foi possível desenvolver um trabalho interdisciplinar.

A única burocracia foi relativa ao uso do laboratório, que deveria ser agendado com antecedência de acordo com disponibilidade e a presença de pelo

menos um monitor do programa Acessa Escola. Foi necessário que o professor apresentasse um plano de aula e os alunos apresentassem o número de suas 
matrículas para que pudessem ter acesso as máquinas. Esse procedimento era necessário pois em 2013 o laboratório de informática passou a contar com a utilização do sistema Blue Control ${ }^{13}$ onde é necessário que os usuários dos computadores sejam identificados para o uso do laboratório.

A utilização do sistema atrasava um pouco o início da atividade mas após o primeiro dia de aplicação com o sistema, o professor, junto com os monitores, organizou uma lista com os nomes e os números de matrículas e a lista de presença por duplas.

A lista de presença era levada até a sala onde era feita a chamada, após a chamada os alunos eram levados ao laboratório de informática que ficava a poucos metros no mesmo corredor das salas pesquisadas.

A chamada era entregue aos monitores e a ordem das duplas era, na medida do possível, a mesma da lista de presença. A cada computador cadastrado o aluno era avisado e iniciava a atividade.

No primeiro dia, ainda sem o esquema acima descrito, o tempo médio para cadastramento de todos os alunos foi de dez minutos, um tempo alto considerando a troca de professor e a chamada para uma aula de cinquenta minutos. Com a dinâmica montada e a agilidade desenvolvida pelos monitores, nos últimos dias de atividades, não ultrapassava cinco minutos.

A observação ocorreu durante 5 aulas por turma, sem contar o primeiro encontro no qual o professor criou com os alunos suas contas Google. As contas Google foram necessárias pois o trabalho era desenvolvido pelos alunos diretamente em um arquivo de texto previamente compartilhado pelo professor

\footnotetext{
${ }^{13}$ O sistema BlueControlWeb gerencia todos os dados do Programa Acessa Escola e disponibiliza aos seus usuários ferramentas para manutenção e acompanhamento das escolas e dos atendimentos. Em: http://suporteinternet.acessaescola.sp.gov.br/BlueControlWeb/
} 
através do site docs.google.com. Houve um maior controle durante as atividades realizadas no computador no ano de 2013 e o índice de "cola" diminuiu.

Após cada aula era confeccionado um diário de campo contendo as passagens ou situações que mais chamaram atenção do pesquisador. A observação teve como critérios norteadores a participação, a motivação, a autonomia, a disciplina e as relações aluno-aluno e professor-aluno.

Os três primeiros tópicos, participação, motivação e autonomia, estão relacionados ao que foi apresentado sobre metodologias de ensino inovadoras que buscam através de situações motivadoras estimular a participação efetiva e autônoma dos alunos no processo de ensino-aprendizagem.

Os itens disciplina, relação aluno-aluno e professor-aluno são requisitos importantes seja qual for a metodologia utilizada. Esses eixos centrais de analise foram pensados antes de qualquer aplicação da atividade, oportunamente outros subitens serão citados e exemplificados.

Durante a análise dos itens, comumente, um item analisado pode servir de subitem aos outros uma vez que os quesitos observados se mostram intimamente relacionados no ambiente escolar, principalmente por tratar-se de uma situação nova à maioria do grupo.

No próximo capítulo apresentarei as análises da aplicação dessa metodoloia para revisar ou construir o conceito de porcentagem. 


\section{Capítulo 3: Resultados e Discussão}

Este capítulo está estruturando em 4 partes. Na primeira descrevo o processo de construção da WebQuest BMW Vermelho, disponível no endereço https://sites.google.com/site/bmwvermelho/home. Na segunda parte o foco é o primeiro contato do professor e das turmas com a WQ. Na segunda analiso o rendimento dos alunos em cada uma das quatro tarefas propostas, levando em conta fatores quantitativos e qualitativos, trazendo resultados medidos através das notas atribuídas e observações quanto a realização das atividades pelos alunos. $\mathrm{Na}$ terceira parte faço uma análise mais profunda da tarefa 4, e comparando a resolução da lista de exercícios que os alunos fizeram antes da aplicação da WQ com a que fizeram como tarefa 4 da WQ.

Por último, na quarta parte, a análise tem como foco a utilização da metodologia WebQuest na construção de conceitos matemáticos e na formação do educando e do professor.

\section{Construção da Webquest}

Levando em consideração a importância do conteúdo de porcentagens e o baixo índice de acertos nas questões do simulado realizado com base nas questões do SARESP elaborei a WebQuest "BMW Vermelho" inspirada em um vídeo de curta-

metragem homônimo, disponível no site Porta Curtas pelo link http://portacurtas.org.br/filme/?name=bmw vermelho.

O vídeo apresenta a história de uma família humilde que é vencedora de um sorteio no qual o prêmio é um BMW vermelho, e que não pode ser vendido no prazo de dois anos. Esta imposição traz diversos problemas para a família ganhadora, que vão desde como assegurar a segurança do veículo e os gastos com impostos e combustível, até a falta de um local para guardá-lo. 
Para o desenvolvimento da WebQuest foi pensada a seguinte situação: Manteve-se o caso do sorteio e das condições da família ganhadora, supondo que fosse dada à família a possibilidade de escolher entre um BMW ou um carro popular, no caso um Nissan March. Os alunos deveriam auxiliar a família a fazer a melhor escolha, tomando por base alguns critérios tais como os custos gerados por cada um dos carros e o impacto ambiental de tal escolha.

Para realizar as tarefas propostas os alunos deveriam rever ou aprender conteúdos matemáticos que os auxiliassem nos cálculos dos gastos, como porcentagem, para calcular os valores IPVA e seguro do carro; proporções para estimar o gasto de combustível para cada veículo em uma viagem; operar com números decimais e média aritmética; além de mobilizar competências e habilidades necessárias para organizar e utilizar de maneira correta as informações coletadas.

Para o desenvolvimento da WQ utilizada nas aplicações foi usada a plataforma oferecida no site http://www.webquestbrasil.org/criador2/, onde é possível encontrar outros modelos de fundo e também WQs feitas por outros professores e alunos de cursos de licenciatura nas mais diversas áreas do conhecimento, abrangendo vários níveis e modalidades de ensino. Qualquer pessoa pode acessar as WQs presentes na plataforma e para criar uma é necessário um breve cadastro sem custo.

Essa plataforma, atualmente, apresenta problemas, e a WQ foi recriada na plataforma https://sites.google.com. Bastar ter uma conta google para que você possa criar um site gratuitamente, e particularmente preferi esse formato ao anteriormente utilizado. Como o google sites destina-se a qualquer tipo de site, a confecção pode ser um pouco mais trabalhosa e demorada porém o resultado final certamente será melhor, principalmente quanto ao layout do site. 
Para aprender a criar a página utilizei o tutorial, "Como criar uma Webquest usando 0 Google Sites", disponível em https://www.youtube.com/watch?v=LyOhGsoBFng. O tutorial é bem feito e ensina passo a passo como criar e formatar sua WQ dentro da plataforma.

Antes de escolher, ainda na primeira plataforma, qual o formato da WQ seria usado, naveguei por WQs que estavam na plataforma, e em outros sites espalhados pela rede, levando em conta o que tinha planejado e julgava importante transmitir aos alunos.

O preenchimento dos campos da WQ é intuitivo, o principal para facilitar o trabalho e poupar tempo é ter feito um bom planejamento de como será realizada a WQ, selecionar previamente os links e fontes a serem disponibilizados para os alunos, definir claramente quais serão as tarefas e como elas serão avaliadas, e escrever em linguagem acessível ao entendimento dos educandos.

Na aba Processo o aluno entrará em contato com o conteúdo, e se queremos desenvolver a autonomia do mesmo devemos ser claros para evitar que o aluno necessite pedir ajuda enquanto busca entender o que deve ser feito.

A seguir exibiremos as telas de cada parte da WQ "BMW vermelho": Introdução, Tarefa, Processo, Avaliação e Conclusões. Cada tela será seguida de um comentário com ideias e colocações feitas durante a atividade, bem como as dificuldades e possíveis soluções encontradas, na elaboração e aplicação da WQ.

As telas apresentadas são da WQ criada no google sites uma vez que a outra encontra-se indisponível na rede, porém as imagens e o texto continuam os mesmos pois por precaução todo o conteúdo estava salvo em um arquivo Word. 


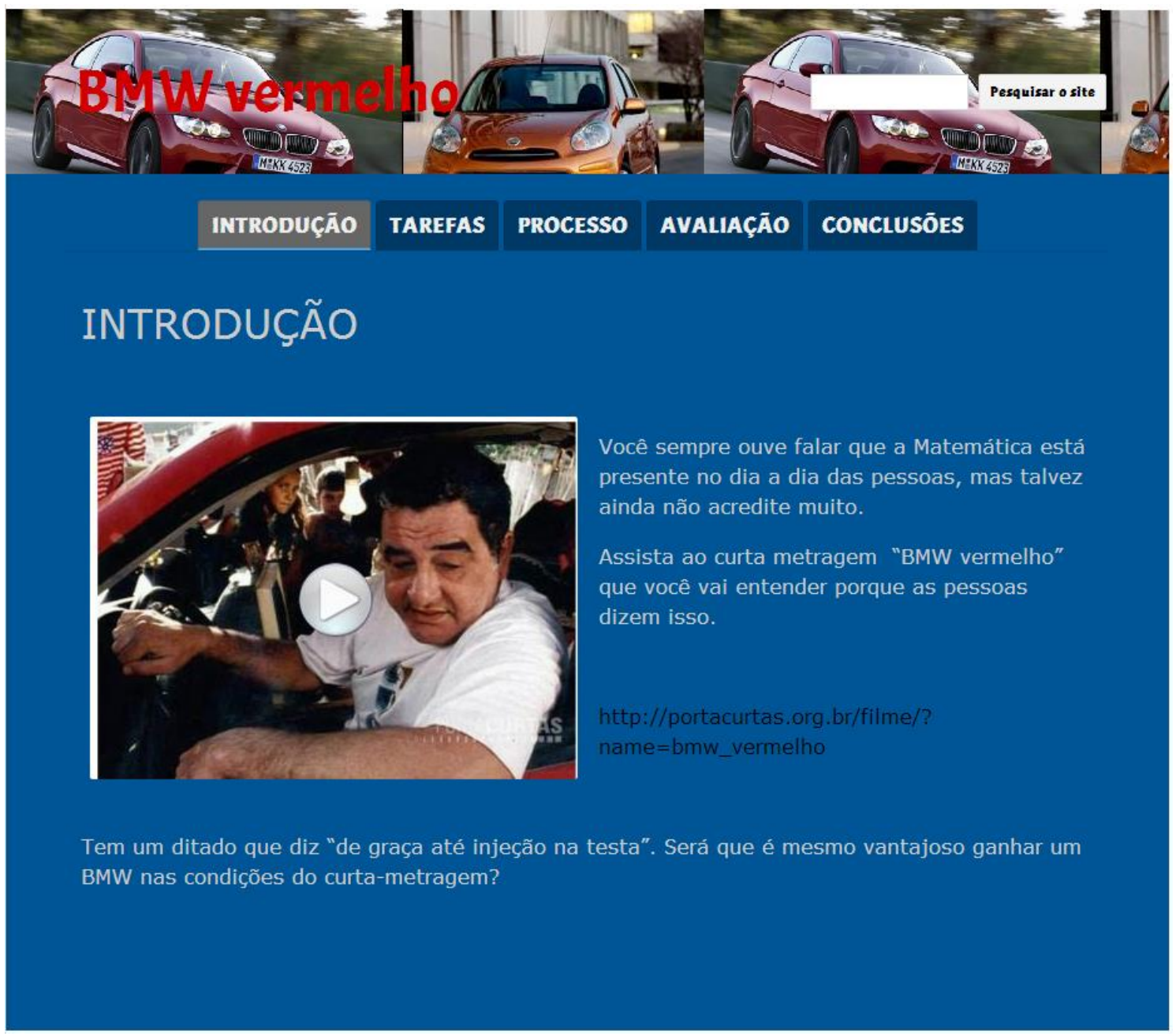

Figura 8- Introdução WQ BMW vermelho https://sites.google.com/site/bmwvermelho/home

Nessa primeira página, a WQ deve despertar o interesse do aluno. Por esse motivo o filme que serviu de inspiração à ideia da WQ aparece logo de cara. O filme é descontraído mas já levanta questões curiosas com relação aos custos para se manter um carro de luxo.

Uma pergunta busca instigar o pensamento dos alunos: "Será que é mesmo vantajoso ganhar um BMW nas condições do curta-metragem?".

Essa é a ponte para apresentar a situação desafiadora e as tarefas, numa linguagem simples, objetiva mas que dialoga com o aluno. O professor pode fazer uso de expressões coloquiais, interjeições, entre outros para motivar o aluno para a atividade. 


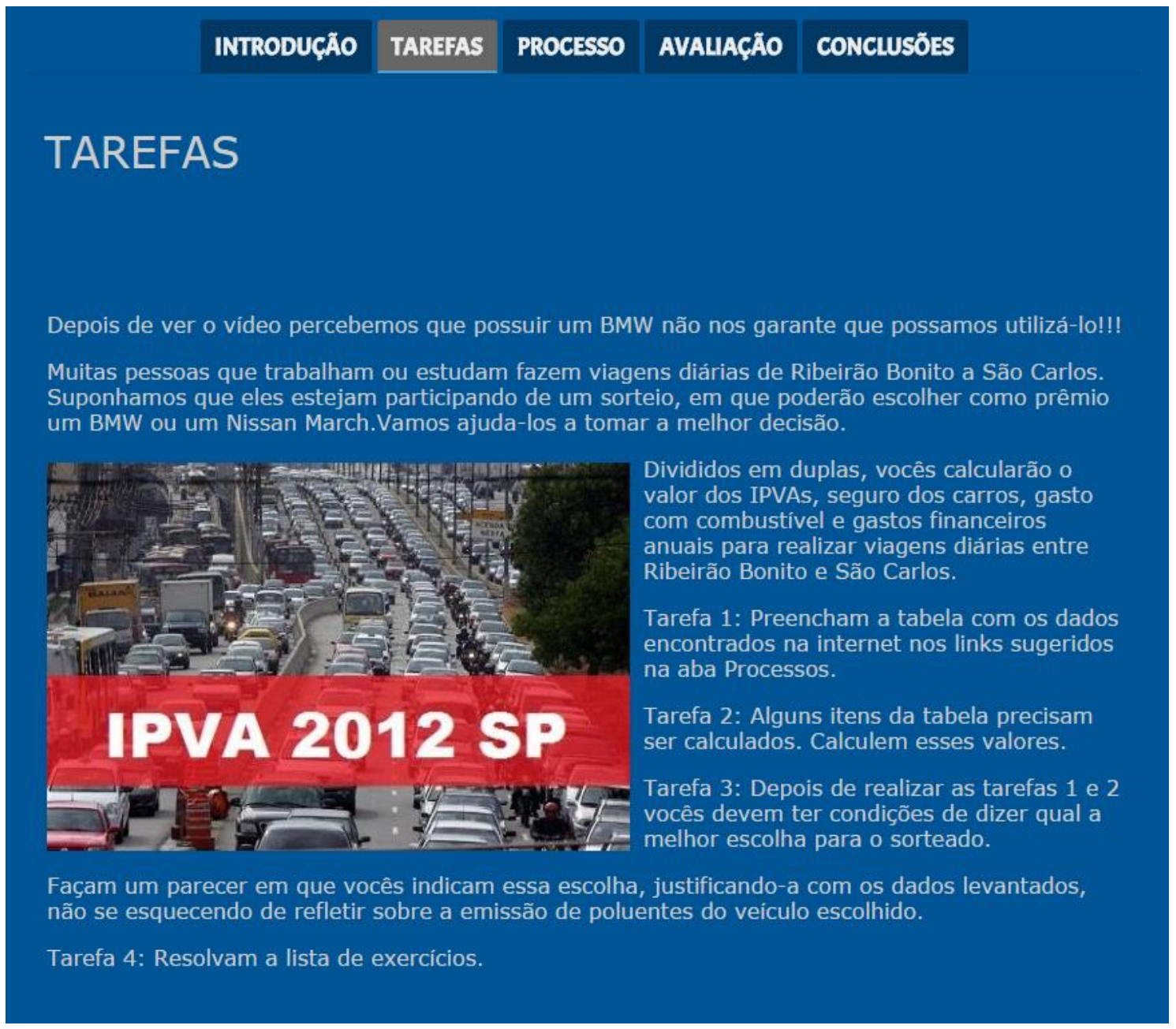

Figura 9- Tarefas WQ BMW vermelho https://sites.google.com/site/bmwvermelho/tarefas

Na aba Tarefas foi apresentada a situação fictícia motivadora das atividades que serão realizadas. Para ajudar os alunos a decidirem pela melhor escolha foram propostas situações do cotidiano, pensando na rota diária de muitas pessoas que moram na mesma cidade na qual eles residem, mas trabalham ou fazem compras em São Carlos, como se observa na Figura 9.

Os alunos deveriam efetuar os cálculos para estimar os gastos anuais para cada tipo de veículo considerando viagens diárias entre as duas cidades, incluindo gastos com seguro e IPVA. 
Depois de realizados todos os cálculos os alunos deveriam decidir qual a melhor escolha para a família fazer no sorteio, a BMW ou o Nissan March, escrevendo um parecer argumentativo sobre o carro escolhido para a família.

Nos itens que se referem às tarefas que devem de fato serem executadas, a linguagem deve ser clara, e a utilização de verbos ajuda a exprimir a ação que o professor espera dos alunos.

Nesse momento a tarefa pode ser mais geral, pois as instruções de como realizá-las estarão na próxima aba - "Processo" (Figura 10) e devem ajudar no entendimento do que deve ser feito.

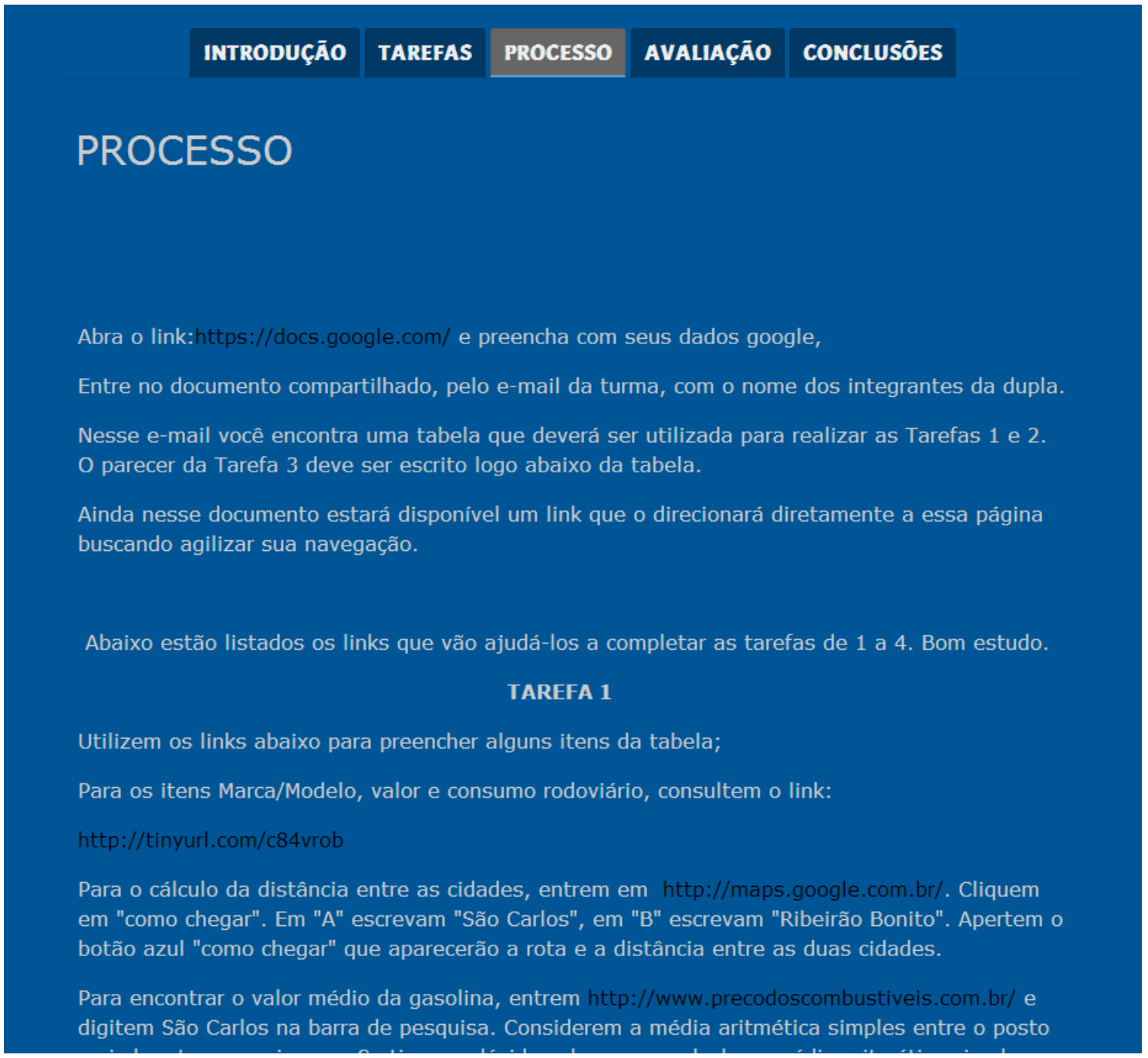

Figura 10- Processo WQ BMW vermelho https://sites.google.com/site/bmwvermelho/processo 
Na página Processo, encontra-se em minha opinião, a parte mais importante da WQ, e por isso esta página deve ser planejada, testada e repensada. É no Processo que o professor orienta para o trabalho, para as atividades a serem realizadas para cumprir cada Tarefa, apresenta os links a serem pesquisados e a forma como cada um deve ser trabalhado.

O planejamento aqui é fundamental, não devem constar links demais para não confundir os alunos e nem de menos para que não fiquem lacunas entre as ideias. A linguagem deve ser clara, pois se a webquest estiver sendo realizada em horário extra classe, o aluno não terá a quem recorrer para avançar na execução das tarefas e se estiver sendo realizada em horário de aula o professor será requisitado por muitos alunos ao mesmo tempo e poderá perder o controle da aplicação da atividade.

Por ser um trabalho mais dinâmico se comparado à resolução de listas de exercícios é comum os alunos apresentarem impaciência se o professor não consegue lhes dar atenção.

Essa foi a única página em que não foi utilizada uma imagem. Isso aconteceu devido ao fato de o conteúdo da página ser extenso e exigir maior concentração dos alunos. Os links são usados no corpo do texto, embora a plataforma de preenchimento do site tenha a opção de se nomear um link com um texto escolhido pelo professor. Entretanto desta forma esses links apareceriam todos juntos ao final da página o que dificultaria o trabalho dos alunos e o desenvolvimento das atividades, visto que são vários os processos a serem utilizados nessa WQ.

Alguns links foram inseridos ao fim da página com curiosidades e vídeos apresentando informações sobre o IPVA, seguro e transporte coletivo, além de fornecer informações pertinentes, esses links tinham a finalidade de preencher 0 
tempo de alunos que realizassem com maior velocidade a tarefa, controlando melhor a disciplina dos mesmos.

Para alguns links foi utilizado um redutor de link, eles diminuem significativamente o tamanho do endereço, são gratuitos e basta uma pesquisa no google para encontrar uma dessas páginas. Nessa WQ foi utilizado o http://tinyurl.com/.

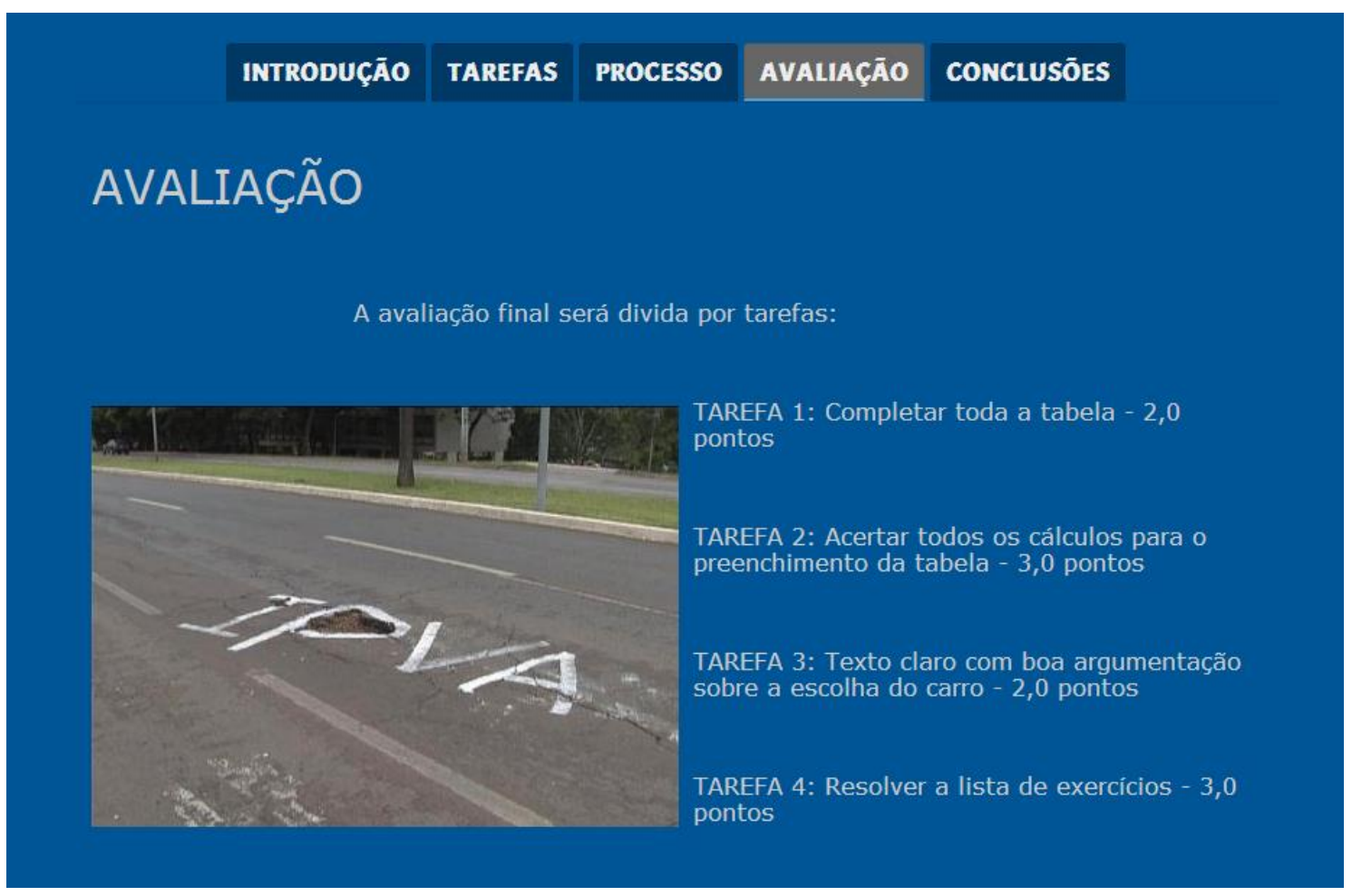

\section{Figura 11 - Avaliação WQ BMW vermelho - https://sites.google.com/site/bmwvermelho/avaliacao}

Na página destinada a avaliação (Figura 11) além de descrever como os alunos seriam avaliados em cada Tarefa e quantos pontos valeria cada atividade, 0 professor explicou, durante a leitura completa da WQ com os alunos, que já estaria disponível em suas contas Google o documento com a tabela que seria preenchida nas tarefas 1 e 2, e que o parecer deveria ser escrito logo abaixo dessa tabela. Explicou também sobre a lista de exercícios que seria entregue a eles para que resolvessem e entregassem para a correção. 
A fotografia que aparece nesta página sugere a avaliação dos alunos sobre a aplicação do dinheiro arrecadado através do IPVA. Algumas questões foram previamente pensadas para serem feitas a toda a sala no momento da aplicação da WQ, tais como: "será que o dinheiro arrecadado vem sendo bem empregado na melhoria das vias de trânsito?", "é direito do cidadão cobrar a boa conservação das vias públicas?".

Embora não estejam explícitas, questões como essas podem auxiliar a formação de um pensamento crítico por parte do aluno.

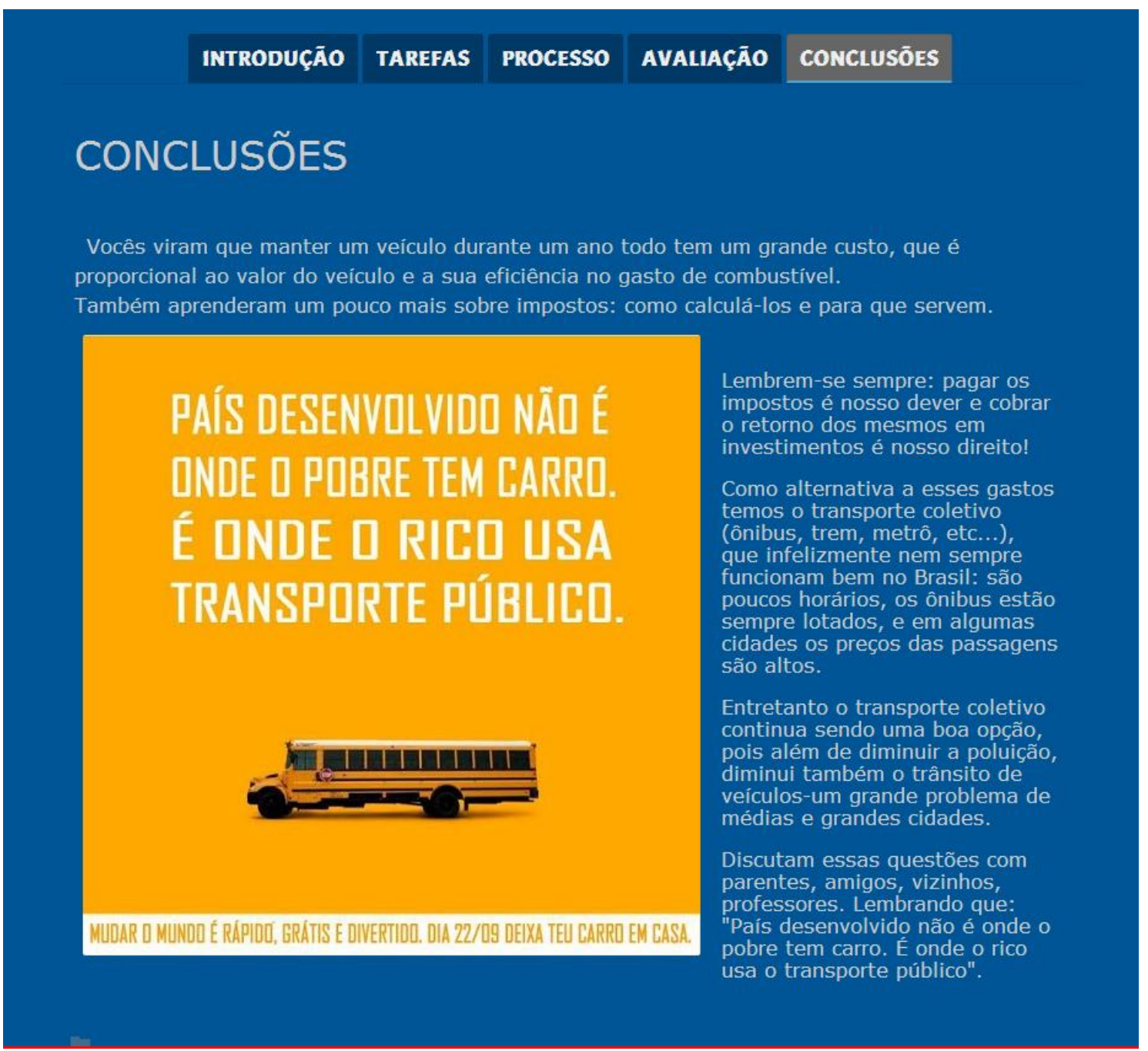

Figura 12 - Conclusões WQ BMW vermelho https://sites.google.com/site/bmwvermelho/conclusoes 
Na última página da WQ (Figura 12) a proposta é um fechamento da atividade, salientando para os alunos o que foi estudado e produzido, e propondo novas reflexões com o intuito de continuar a discussão.

A reflexão final procura introduzir na discussão a utilização do transporte coletivo como alternativa de locomoção, mais barata, menos poluente e que ajuda a melhorar o trânsito nas cidades.

O texto incentiva a discussão das questões abordadas durante a WQ com familiares, amigos e outros professores, procurando ampliar o entendimento e a compreensão desses temas, por parte do aluno, em contato com o meio social onde está inserido, levando questionamentos que às vezes passam despercebidos em seus cotidianos.

Na imagem a conclusão é explicita: "País desenvolvido não é onde o pobre tem carro. É onde o rico usa transporte público".

\section{Análise das tarefas}

Para a análise das tarefas realizadas na WQ foram considerados os dados quantitativos e em algumas análises foram utilizados extratos das tarefas dos alunos buscando uma abordagem qualitativa.

A Tarefa 1 consistia em preencher uma tabela com informações sobre a marca, o modelo, o valor e o consumo rodoviário dos veículos a serem comparados (BMW e Nissan), também a distância entre São Carlos e a cidade em que os alunos residiam, preço médio do combustível, quantidade de dias úteis em cada ano. As tabelas foram previamente disponibilizadas para os alunos em suas contas de email. Tal tarefa poderia valer até 2,0 pontos, foi levado em consideração o preenchimento correto da tabela. No total eram 9 itens e cada item tinha o valor de 0,2 ponto, totalizando 1,8 . Todas as duplas que preencheram a tabela receberam 
0,2 ponto de participação, chegando assim a nota máxima 2,0 . Foi descontado 0,1 ponto dos itens que apresentavam pequenos erros, como por exemplo omitir a parcela decimal de um número ou a unidade de medida nos casos de distância e consumo. $O$ desempenho dos alunos pode ser observado nas Tabela 1.

Para realizarem essa tarefa os alunos deveriam ler e interpretar informações e dados apresentados em tabelas e terminar de construir a tabela navegando pelos links selecionados pelo professor, que estavam disponíveis na WQ. Em primeiro lugar deveriam selecionar as informações sobre a marca, o modelo, o valor e o consumo rodoviário dos dois automóveis em uma tabela comparativa e preencherem suas tabelas com esses dados.

O próximo item da tarefa buscava aproximar os alunos das novas tecnologias disponíveis na Internet, no caso o google maps (www.google.com.br/maps) explorando a sua funcionalidade para calcular possíveis rotas de uma viagem. A ferramenta exibe um mapa com o trajeto a ser utilizado com informações sobre 0 mesmo, como a presença de pedágios, a duração da viagem e a distância percorrida. Para essa tarefa o importante a informação exigida era a distância de cada viagem.

Para que os alunos coletassem os dados sobre o preço médio do combustível em São Carlos e o número de dias úteis em cada ano, foram disponibilizados dois links. No site http://www.precodoscombustiveis.com.br/ é possível encontrar os preços dos combustíveis nos principais postos da cidade mas infelizmente nem todas as cidades estão cadastradas e no site http://www.diasuteis.com/ é fácil verificar o número de dias úteis em um determinado período. Os dois sites possuem interfaces simples e intuitivas, a maioria dos alunos não precisou de ajuda para realizar esses passos da tarefa, bastou seguirem os processos sugeridos pelo professor. 
Como se observa na Tabela 1 o rendimento dos alunos foi muito bom e apenas duas duplas apresentaram nota 1,80 muito próxima a nota máxima, 2,00. Os erros observados pelas duplas eram referentes a apresentação dos dados na tabela, pequenos erros quanto a localização da vírgula ou omissão da unidade de medida em algum item, não havendo erros graves.

Tabela 1- Distribuição das notas dos alunos na Tarefa 1

\begin{tabular}{|l|l|}
\hline Nota & $f(2013)$ \\
\hline 1,80 & 4 \\
\hline 2,00 & 43 \\
\hline Média da turma & 1,98 \\
\hline
\end{tabular}

Nessa tarefa a maioria dos alunos conseguiu nota máxima, e a menor nota foi 1,80 . Fica claro pela média da turma que a maior parte dos alunos dominava as habilidades necessárias para preencher a tabela. A melhor pontuação pode ser consequência de uma melhor orientação prévia por parte do professor sobre como os alunos deveriam proceder na realização das tarefas. O controle de "colas" foi intensificado durante essa aplicação.

$\mathrm{Na}$ figura 13, apresentamos o protocolo que contém a Tarefa 1 realizada por uma dupla. Na coluna da esquerda podemos ver o tipo de dado a ser preenchido na tabela, e as duas colunas a frente são destinadas ao preenchimento de cada veículo. Nesse protocolo observa-se que a dupla considerou a distância de ida e volta como $95 \mathrm{~km}$ ao invés de $94 \mathrm{~km}$, que seria o correto. Acredito que esse erro tenha ocorrido por falta de atenção. Como o restante dos cálculos estão corretos se considerarmos o valor de 95km, nada foi descontado na Tarefa 2. 


\begin{tabular}{|l|l|l|}
\hline Marca/Modelo & $\mathrm{BMW}$ & march $1.016 \mathrm{v}$ \\
\hline Valor & $\mathrm{R} \$ 459665,00$ & $\mathrm{R} \$ 24160,00$ \\
\hline Consumo rodoviário (km/l) & $10,2 \mathrm{~km} / \mathrm{l}$ & $14,5 \mathrm{~km} / \mathrm{l}$ \\
\hline Distância da viagem (ida e volta) & $95,0 \mathrm{~km}$ & $95,0 \mathrm{~km}$ \\
\hline $\begin{array}{l}\text { Preço da gasolina (média entre o posto } \\
\text { mais caro e o mais barato) }\end{array}$ & $\mathrm{R} \$ 2,79$ & $\mathrm{R} \$ 2,79$ \\
\hline Custo anual das viagens (253 dias úteis) & $\mathrm{R} \$ 6570,41$ & $\mathrm{R} \$ 4622,31$ \\
\hline
\end{tabular}

Figura 13 - Extrato do protocolo dos alunos A16a2013 e A17a2013 na Tarefa 1.

$\mathrm{Na}$ Tarefa 2, cada um dos 14 itens valia 0,2 ponto e todas as duplas recebiam 0,2 ponto de participação, ou seja, a nota máxima era de 3,0 pontos. A correção seguiu a mesma, sendo descontado 0,1 ponto por pequenos erros.

Nessa Tarefa os alunos deveriam calcular os resultados necessários para preencher o restante da tabela. Os dados a serem calculados eram, IPVA, seguro, consumo de combustível por viagem, custo por viagem, custo anual das viagens, gastos anuais com o carro (incluindo o IPVA, o Seguro e as viagens) e por último o gasto médio mensal (incluindo o IPVA, o Seguro e as viagens), para cada carro.

É nessa tarefa que o aluno entra em contato com o conteúdo matemático. É a atividade mais importante na consolidação dos conceitos matemáticos, pois realizando os cálculos com a ajuda de sites educacionais que auxiliam no entendimento das operações e também com as instruções presentes na WQ os alunos utilizam a matemática como uma ferramenta para resolver o problema de uma maneira significativa e não como uma aplicação descontextualizada. 


\section{Tabela 2- Distribuição das notas dos alunos na Tarefa 2}

\begin{tabular}{|l|l|}
\hline Nota & $f(2013)$ \\
\hline 1,40 & 2 \\
\hline 2,10 & 1 \\
\hline 2,20 & 1 \\
\hline 2,30 & 6 \\
\hline 2,50 & 2 \\
\hline 2,60 & 2 \\
\hline 2,80 & 6 \\
\hline 2,90 & 6 \\
\hline 3,00 & 21 \\
\hline Média da turma & 2,72 \\
\hline
\end{tabular}

A média das turmas na Tarefa 2 foi muito boa, 2,72, como mostrado na Tabela 2. Das 22 duplas e 3 alunos que fizeram individualmente, 10 duplas e um dos alunos que fez individualmente conseguiram a nota máxima da Tarefa evidenciando, mais uma vez, o bom desempenho dos alunos na revisão ou aprendizagem dos conteúdos e dos cálculos explorados na Tarefa. Foi interessante ver os alunos interessados em realizar os cálculos, curiosos por seus resultados.

O menor rendimento, 1,40 , abaixo da metade da nota máxima, foi registrado pela dupla de alunos A7b2013 e A8b2013 que abandonaram a resolução da atividade no meio, realizando apenas alguns itens da Tarefa 2. Esses alunos não voltaram durante os outros dias de aplicação e não realizaram mais Tarefa alguma da WQ. O mesmo aconteceu com o aluno A7a2013 $(2,10)$ que também não completou todas as Tarefas. Já a dupla de alunos A8a2013 e A9a2013, cujo extrato do protocolo se encontra na Figura 14, apresentou rendimento de 2,30. Eles cometeram alguns erros de cálculo considerados graves como no custo anual das viagens que deveria ser $\mathrm{R} \$ 6.834,35$ e eles encontraram $6.625,00$. Os alunos 
utilizaram para o cálculo do Custo anual das viagens o valor da viagem igual a $R \$$ 25,00, ou seja, fizeram um arredondamento do valor que está escrito na tabela. Novamente um erro por falta de atenção.

Erros relacionados a localização de vírgula, ou mesmo omissão dos centavos foram considerados pequenos como nos cálculos do IPVA, seguro e custo por viagem que deveriam ser $R \$ 18.386,60, R \$ 32.176,55$ e $R \$ 25,97$, respectivamente.

Nos cálculos do IPVA e gastos anuais com o March que deveriam ser R $\$$ 966,40 e $R \$ 7.498,75$, respectivamente. Os demais itens foram calculados corretamente pela dupla.

\begin{tabular}{|l|l|l|}
\hline Valor IPVA (4\% do valor do carro) & $\mathrm{R} \$ 18386,00$ & $\mathrm{R} \$ 966,00$ \\
\hline Valor seguro (média entre 4 e 10\%) & $\mathrm{R} \$ 32176,00$ & $\mathrm{R} \$ 1691,20$ \\
\hline Consumo de combustivel por viagem & $9,31 \mathrm{I}$ & $6,55 \mathrm{I}$ \\
\hline Custo por viagem & $\mathrm{R} \$ 25,79$ & $\mathrm{R} \$ 18,27$ \\
\hline Custo anual das viagens (265 dias úteis) & $\mathrm{R} \$ 6625,00$ & $\mathrm{R} \$ 4841,55$ \\
\hline $\begin{array}{l}\text { Gastos anuais com o carro (incluindo o } \\
\text { IPVA, o Seguro e as viagens) }\end{array}$ & $\mathrm{R} \$ 57187,00$ & $\mathrm{R} \$ 7498,00$ \\
\hline $\begin{array}{l}\text { Gasto médio mensal (incluindo o IPVA, } \\
\text { Seguro e as viagens) }\end{array}$ & $\mathrm{R} \$ 4765,58$ & $\mathrm{R} \$ 624,83$ \\
\hline
\end{tabular}

Figura 14 - Extrato do protocolo dos alunos A8a2013 e A9a2013 na Tarefa 2.

Observa-se que os alunos desprezaram os valores das casas decimais, com exceção do Custo por viagem, onde aparece $R \$ 25,79$ o correto seria $R \$ 25,97$, o que caracteriza um erro de atenção.

O aluno A8a2013 apresentava um rendimento mediano na disciplina de matemática, mas infelizmente faltava muito às aulas o que atrapalhava o seu desenvolvimento e as conexões entre os conteúdos, sem falar na sua dificuldade em escolher estratégias para resolução de problemas. 
Por outro lado o aluno A9a2013 apresentava muita dificuldade não somente em matemática, seu rendimento era baixo em praticamente todas as disciplinas e havia sempre uma preocupação especial com seu aprendizado que era dificultado por seus problemas de indisciplina.

Diante do exposto e visto que os erros não afetavam a situação de aprendizagem como um todo uma vez que os resultados finais foram bem próximos aos esperados, considera-se que mesmo esses alunos que não conseguiram a nota máxima apresentaram um bom rendimento se comparado ao que apresentavam em sala de aula.

Em aulas usuais era difícil receber alguma devolutiva desses alunos, seja por não conseguirem interpretar os problemas ou por não saberem o conteúdo, esses alunos sempre apresentavam grande apatia durante as aulas, mas motivados conseguiram superar as expectativas e foi gratificante ver a reação dos mesmos ao terminar a Tarefa e chegar ao valor mensal. Estavam contentes por conseguirem terminar as tarefas e surpresos com os valores encontrados. Infelizmente foi difícil motivá-los a escrever.

Os dados parecem indicar um bom comprometimento dos alunos com a atividade e também que, após a orientação do professor, a maior parte das duplas conseguiu resolver o que foi proposto pela $W Q$ de maneira satisfatória e independente.

A Tarefa 3 tinha como meta a escrita de um parecer embasado nos resultados obtidos e disponíveis na tabela, após os cálculos, indicando qual deveria ser a escolha da família.

É frequentemente comentado pelos professores que os alunos não têm um nível adequado nas competências leitoras e escritoras. Realmente é difícil para alguns alunos expressarem suas ideias através de textos. Nas vezes em que utilizei 
a produção de texto em minhas aulas, o que não era comum, me deparei com um problema para o qual não me sentia preparado para resolver. Os textos derivados de pesquisas eram, na maioria das vezes, cópias na integra de algum site.

Buscando então trabalhar a rodução de texto dos alunos a ideia foi que os mesmos escrevessem um parecer, um texto onde eles deveriam colocar suas ideias e suas conclusões frente aos dados pesquisados e calculados por eles na tabela. Dessa forma os alunos não poderiam simplesmente copiar um texto explicativo sobre uma questão pesquisada. Eles deveriam argumentar sobre a melhor escolha para a família e conferindo aos dados obtidos novos sentidos, analisando-os dentro da realidade de uma família brasileira.

Ficou claro durante o estudo piloto que essa tarefa merecia maior atenção. Foi a tarefa mais rejeitada inicialmente pelos alunos. Além de pedirem para que não precisassem escrever um texto, quando o faziam era um texto curto, com valores da tabela e uma conclusão óbvia como: "Porque um carro comum gasta menos, e você economiza mais do que uma BMW", como expressaram os alunos A7a2012 e A8a2012.

A maior parte dos textos escritos no estudo piloto estava mal embasada e apenas repetiam os dados que estavam na tabela dizendo que o custo para manter a BMW era maior do que o custo para manter o Nissan. A primeira reação após a correção dos textos foi buscar um trabalho interdisciplinar com a professora de português o que ficou inviabilizado pelo pouco tempo disponível para o encontro com a mesma e a dificuldade encontrada pela professora com a utilização das ferramentas tecnológicas com as quais o trabalho foi desenvolvido.

Ainda que não tenha participado diretamente das atividades a professora de português ajudou com dicas do que poderia ser feito para uma melhora nas produções textuais. Foi sugerido e acatado que durante a explicação e execução da 
tarefa o professor mostrasse caminhos que ajudassem os alunos a formar uma opinião, a defender um ponto de vista e entender o que os números representavam dentro de uma realidade, dentro de suas realidades.

Então durante a aplicação foi comum que, quando os alunos estavam terminando os cálculos ou começando a escrever o parecer, o professor questionasse as duplas sobre quanto uma pessoa deveria ganhar pra manter cada um dos carros, de quanto era a diferença de gastos anuais ou mensais entre os carros, se seria possível para um brasileiro comum manter um carro de luxo como o BMW, se era vantajoso ter um carro se você precisa se deslocar todo dia ou era melhor utilizar o transporte público, e ainda, questões ambientais ligadas ao consumo de combustível de cada carro.

Cada aluno seguiu um caminho na escrita, a maioria se atentou às questões econômicas, ligadas ao salário ou ao valor do custo anual aproximar-se ao de uma casa, mesmo que simples. Poucas duplas defenderam a utilização do transporte público ou consideraram questões ambientais.

Aqui se abriria espaço para a interação interdisciplinar com Ciências, Geografia e talvez História. Ciência poderia tratar das questões ambientais e mostrar alternativas menos poluentes enquanto Geografia e História poderiam trazer um panorama político e social para a questão utilizando, por exemplo, as manifestações do movimento Passe Livre que durante o ano de 2013 tomou as ruas das principais capitais em busca de melhores condições para o transporte público no país.

Mesmo com um olhar mais atento do professor que buscou estimular a escrita e fornecer caminhos às suas argumentações, nem todas as duplas conseguiram realizar de forma satisfatória a escrita do parecer e alguns alunos chegaram a se recusar a realizar a tarefa alegando que não precisavam mais de 
nota pois haviam completado os pontos necessários para serem aprovados no ano letivo.

Por outro lado algumas duplas chegaram a surpreender ao pesquisarem a média salarial do brasileiro e também o valor do salário mínimo para complementarem seu parecer, essas duplas escreveram textos contextualizados, reflexivos e críticos, o que nos leva a crer que a Tarefa 3 assumiu um papel importante dentro da WQ instigando e abrindo espaço para as opiniões dos alunos e os ajudando a entender de maneira mais complexa a realidade na qual estão inseridos.

A Proposta Curricular do Estado de São Paulo coloca como prioridade o desenvolvimento das habilidades e competências relacionadas a leitura e a escrita em todas as disciplinas. E explicita que:

Representar, comunicar e expressar são atividades de construção de significado relacionadas a vivências que se incorporam ao repertório de saberes de cada indivíduo. Os sentidos são construídos na relação entre a linguagem e o universo natural e cultural em que nos situamos. E é na adolescência, como vimos, que a linguagem adquire essa qualidade de instrumento para compreender e agir sobre o mundo real. (SÃO PAULO, 2008, p. 16)

Embora as dificuldades possam desanimar alguns professores a continuarem insistindo nas produções textuais em suas aulas, essa realidade somente deixa mais clara a necessidade de continuarmos a nos preocupar com a competência leitora e escritora dos alunos estimulando-as em suas produções textuais.

A Tabela 3 apresenta o aproveitamento dos alunos na Tarefa 3. 


\section{Tabela 3 - Distribuição das notas dos alunos na Tarefa 3}

\begin{tabular}{|l|l|}
\hline Nota & $f(2013)$ \\
\hline 0,00 & 4 \\
\hline 0,20 & 2 \\
\hline 0,30 & 2 \\
\hline 0,50 & 2 \\
\hline 0,80 & 8 \\
\hline 1,00 & 4 \\
\hline 1,20 & 5 \\
\hline 1,30 & 6 \\
\hline 1,50 & 6 \\
\hline 1,70 & 2 \\
\hline 1,80 & 6 \\
\hline Média da turma & 1,05 \\
\hline
\end{tabular}

Se calcularmos a média desconsiderando os 4 alunos que resolveram não escrever o parecer ou terminar o restante da WQ alegando não gostarem de escrever e já terem superado a nota necessária para serem aprovados teremos a média de 1,14. Essa tarefa foi a que os alunos apresentaram o menor desempenho, embora a maior parte das notas esteja acima da metade da pontuação máxima possível na tarefa. Dos 47 alunos, 4 não fizeram, 14 tiveram nota inferior a metade da pontuação da tarefa e 29 obtiveram nota superior a metade da pontuação, ou seja, ainda assim o rendimento foi satisfatório.

A correção de 2013 sofreu influência das conversas com a professora de português tornando-se mais rigorosa.

Além dos alunos que não realizaram a tarefa, alguns alunos a realizaram de maneira insatisfatória, ou o deixaram incompleta, como é o caso da dupla A18a2013 e A19a2013 que escreveu: 
o bmw e muito bonito mais o ipva dele e muito caro e so pode vender ele depois de dois anos eo nissam march o ipva dele e mais barato eu prefiro o nissam march vc pode andar com ele porque e mais barato vc sabe neh eo bmw e muito caro so pra tirar da garagerm vc tem que gastar muito com ele eo nissam march vc pode andar com ele na rua porque o ipva dele e mais barato e o combinado do sorteio e muito ruin

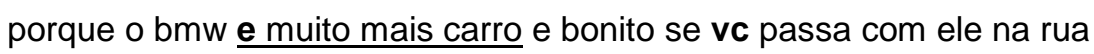
todo mundo olha eu prefiro comprir o sorteio com o bmw e depois que acabar os dois anos eu vendo ele ai eu vou pegar um dinheiro bom com o bmw vermelho e etc...

No texto estão em negrito as palavras grafadas erradas e, sublinhados os erros de concordância. Nota-se que os alunos não tiveram preocupação em utilizar corretamente a pontuação e o texto é uma colagem de várias frases soltas. A dupla mesmo identificando que os gastos do BMW são maiores foi a única a sugerir a escolha do BMW, mesmo que fosse necessário esperar dois anos para poder vender e "pegar um bom dinheiro". Nota-se no texto que a primeira sugestão da dupla foi escolher o Nissan o que deixa a impressão que cada membro da dupla tinha uma opinião e eles não chegaram a um acordo.

Nenhuma dupla atingiu a nota máxima da tarefa, mas muitas duplas obtiveram um bom rendimento, 6 alunos ou seja, 3 duplas, conseguiram nota 1,80, apresentando pequenos erros porém com boas ideias que nos chamaram atenção positivamente. As reflexões e questionamentos que levaram alguns alunos e alunas a realizarem pesquisas para embasar melhor seus argumentos diante da realidade brasileira evidenciam o espaço aberto para que o aluno expresse sua maneira de entender o conteúdo, ainda mais se comparado ao ensino tradicional de matemática onde a resposta final é, em geral, um número. Duas duplas pesquisaram dados 
referentes ao valor do salário no Brasil. As alunas A22b2013 e A23b2013 pesquisaram o valor do salário mínimo e concluíram que:

Com a BMW o custo anual será de $\mathrm{R} \$ 57062,72$ e o carro popular gastará $R \$ 7229,31$, portanto só uma pessoa que tenha uma estrutura econômica boa, ou seja, que ganhe mais que de um salário minimo que conseguirá mantê-lo. (extrato do protocolo de A22b2013 e A23b2013)

Essas alunas utilizaram os dados que haviam calculado e a pesquisa sobre o valor do salário mínimo para tirar uma conclusão mais signficativa, conferindo um peso, uma medida, um valor aos números obtidos, o que representa o principal intuito na escrita do parecer.

Acompanhando e auxiliando os alunos na escrita do parecer e analisando o produto final, é possível entender como o aluno se relaciona com os números não somente quanto aos cálculos matemáticos mas sim o que representa aquele valor dentro de um contexto prático ligado a realidade desse aluno.

Nesse sentido, as alunas A20b2013 e A21b2013, apresentaram o melhor desempenho. Depois de pesquisar qual é a média salarial do brasileiro, pediram a ajuda do professor para calcular qual porcentagem do salário médio seria comprometida com os gastos mensais para o veículo popular, uma vez que o valor gasto mensalmente para a manutenção da BMW chega a ser maior do que o dobro do salário médio. Embora apresentem um erro na escrita, escreveram: "A média do salário brasileiro custa $R \$ 1792,61$, e por ano $R \$ 21511,32$,ou seja, $33,60 \%$ do salário seria destinado ao consumo do carro“. O texto traz uma utilização da porcentagem que não foi explorada na WQ causando surpresa ao professor, evidenciando a potencialidade para estimular a extrapolação pelos aprendizes. 
Os cálculos relacionados a porcentagem previstos na WQ foram usados para calcular quanto representava $4 \%$ do valor do veículo no caso do IPVA e $7 \%$ do valor do veículo para o seguro. A ideia de quanto uma quantia representa percentualmente em relação a outra não foi explorada, porém como as alunas necessitavam desse conceito para defender suas ideias, o professor as auxiliou a encontrar na Internet como realizar esse cálculo e fez uma breve explicação.

Nesse momento o professor verdadeiramente atuou como um mediador, auxiliando e guiando as alunas na construção de seus conhecimentos através de uma experiência concreta e utilizando-se das TICs de maneira integrada a aula. A situação mostrou-se motivadora novamente e ainda forneceu argumentos que corroboram a tese de que a WQ tem como ator principal o educando e o professor como mediador. As próprias alunas buscavam naquele momento o conhecimento e encontraram no professor alguém que pudesse guiá-las.

Após a escrita do parecer restava a Tarefa que consistia na resolução da lista de exercícios com problemas semelhantes aos trabalhados na WQ e envolvendo os mesmos conteúdos. Essa lista foi entregue impressa aos alunos e também estava presente em um link da WQ.

Nas aplicações de 2013 os alunos realizaram a Tarefa 4 individualmente enquanto no estudo piloto a realização se deu em duplas. A mudança ocorreu porque em 2013 os alunos foram solicitados a resolver a mesma lista antes do contato com a WQ e depois como Tarefa da mesma, servindo de subsídio de análise, para evidenciar melhor qual era o domínio do conteúdo, ou a capacidade de resolver aqueles problemas, antes e depois das atividades propostas na WQ.

A seguir serão apresentadas as notas dos alunos nessa tarefa. As duplas/alunos que apresentam 0,00 como nota não entregaram a lista para correção. Os dados apresentados são referentes a lista realizada durante a 
aplicação da WQ. A comparação entre os rendimentos antes e depois da aplicação da WQ será feita no próximo tópico.

Tabela 4 - Frequência das notas na Tarefa 4 (2013)

\begin{tabular}{|l|l|}
\hline Nota & $f(2013)$ \\
\hline 0,00 & 6 \\
\hline 0,25 & 1 \\
\hline 0,50 & 1 \\
\hline 1,00 & 2 \\
\hline 1,40 & 3 \\
\hline 1,50 & 2 \\
\hline 1,60 & 1 \\
\hline 1,75 & 1 \\
\hline 1,80 & 1 \\
\hline 2,00 & 2 \\
\hline 2,10 & 1 \\
\hline 2,25 & 1 \\
\hline 2,40 & 2 \\
\hline 2,50 & 3 \\
\hline 2,60 & 1 \\
\hline 2,70 & 6 \\
\hline 2,80 & 3 \\
\hline 2,90 & 6 \\
\hline 3,00 & 4 \\
\hline Média da turma & 1,96 \\
\hline &
\end{tabular}

Com base nos dados da Tabela 4 observa-se que 6 alunos obtiveram a nota mínima zero e 4 obtiveram a nota máxima possível 3 pontos. A média da turma foi de 1,96. Se considerarmos somente as listas corrigidas, a média é de 2,25, uma ótima média da turma já que a Tarefa tinha valor máximo de 3,0 pontos. 
Infelizmente 7 dos alunos que entregaram a lista para correção apresentaram nota menores do que a metade da pontuação máxima, todos alunos da $8^{a} \mathrm{~A}\left(9^{\circ} \mathrm{A}\right)$. A menor nota da $8^{\circ} \mathrm{B}\left(9^{\circ} \mathrm{B}\right)$, foi igual a 1,50 , exatamente metade da nota máxima, atingida pelo aluno A19b2013, que embora seja um bom aluno muitas vezes se apresenta cansado e sonolento nas aulas da tarde pois é de conhecimento de toda a comunidade escolar que o aluno há muito tempo trabalha plantando, colhendo e vendendo verduras pela cidade durante o período da manhã.

Se analisarmos o desempenho das duplas por sala na lista de exercícios da Tarefa 4 perceberemos uma variação maior nas notas entre os membros das duplas

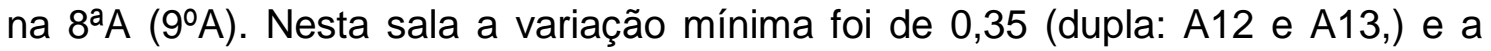
máxima de 2,0 (dupla: A18 e A19).

Já na $8^{\mathrm{a}} \mathrm{B}\left(9^{\circ} \mathrm{B}\right)$, notamos que a maior variação foi de 0,5 ponto para duas duplas (duplas: A7 e A8 / A13 e A14) já a dupla formada pelas alunas A9b2013 e A10b2013 foi o único caso em que os dois membros da dupla tiraram a mesma nota, no caso, a nota máxima.

Com conhecimentos prévios, motivação e dedicação muito variada, algumas duplas da $8^{\mathrm{a}} \mathrm{A}\left(9^{\circ} \mathrm{A}\right)$ dividiram o trabalho, mesmo que o professor tenha salientado a importância de que todos realizassem todas as etapas da WQ. A divisão das tarefas entre os membros da dupla pode ter comprometido a aprendizagem de alguns alunos.

Quanto às duplas da $8^{\mathrm{a}} \mathrm{B}\left(9^{\circ} \mathrm{B}\right)$, essas trabalharam de maneira colaborativa e foi possível notar um maior empenho e motivação dos alunos na realização das Tarefas da WQ, o que certamente favoreceu o aprendizado dos dois membros da dupla, levando-os a terem rendimentos parecidos na Tarefa 4. 


\section{Análise da Aprendizagem}

Esse tópico pretende analisar a melhora na aprendizagem dos alunos. Para essa análise serão considerados apenas os dados dos alunos das duas turmas que resolveram a lista de exercícios antes e depois da aplicação da WQ. A amostra foi definida pelos alunos presentes nas duas datas, devido ao número excessivo de faltas dos alunos foi possível coletar apenas 29 notas, 12 da turma A e 17 da turma B, das 47 possíveis.

A análise se dividirá em dois momentos. No primeiro momento analisaremos os dados de maneira quantitativa procurando evidenciar o crescimento no número de itens respondidos corretamente após a aplicação da WQ. Essa análise será feita turma a turma, e em seguida, será feita um análise conjunta, considerando os 29 alunos.

O segundo momento da análise será qualitativo e serão analisadas as estratégias, os erros e a comparação entre as respostas do aluno antes e depois da aplicação da WQ, procurando evidenciar a aprendizagem através da metodologia aplicada.

Para organizar e interpretar os dados estatísticos obtidos com a utilização do programa SPSS (Statistical Package for the Social Sciences) um pacote estatístico

para as ciências sociais, foram gerados gráficos e tabelas, comparando o rendimento dos alunos nos 14 itens presentes na lista de exercícios. Para cada aluno foi atribuído um valor de 0 a 10 de acordo com os acertos na lista de exercícios que foi realizada antes e depois da aplicação da WQ.

A lista de exercícios continha problemas relacionados ao tema trabalho, salvo a questão 1 em que a proposta era a aplicação direta do cálculo de porcentagem. 
Os alunos garantiriam 0,20 pontos por entregarem a lista resolvida, e cada um dos 14 itens a serem respondidos valiam 0,20 pontos, totalizando os 3,00 pontos da Tarefa 4. Vale ressaltar que para análise feita por meio dos gráficos foram considerados apenas os acertos ou erros aos itens e os valores foram normatizados para uma faixa entre 0 e 10. Com os gráficos normatizados buscou-se uma abordagem quantitativa dos dados.

\section{Tabela 5- Comparativo da turma A - Antes e Depois da WQ}

\begin{tabular}{|l|l|l|}
\hline & ANTES & DEPOIS \\
\hline Média & 1,4583 & 5,7917 \\
\hline Mediana & 2,1000 & 5,1500 \\
\hline Desvio Padrão & 0,91796 & 2,52675 \\
\hline Mínimo & 0,00 & 2,10 \\
\hline Máximo & 2,10 & 9,60 \\
\hline
\end{tabular}

A partir da análise da Tabela 5 percebemos que houve melhora no desempenho dos alunos após a aplicação da WQ. O valor máximo atingido pelos alunos da turma A na primeira aplicação, 2,10, foi o valor mínimo encontrado na aplicação que foi realizada depois, que teve como máximo, 9,60. Ainda na mesma tabela fica evidente que os alunos melhoraram as estratégias para resolver os exercícios se nos atentarmos a média, aproximadamente 5,8 e para a mediana 5,15 , o que nos revelam que a maior parte dos alunos conseguiu resolver mais do que a metade dos exercícios.

Embora os resultados sejam singelos e a amostra pequena, há indicação de uma contribuição da metodologia, principalmente se considerarmos que o valor de 
2,10 representa 3 itens corretos e após uma análise mais profunda chegou-se a conclusão que esses itens respondidos corretamente na grande maioria das vezes eram os problemas de proporcionalidade. Ou seja, nessa turma, antes da aplicação da WQ a maioria não havia resolvido nenhum exercício de porcentagem. Por outro lado ao analisar o desempenho da turma na segunda aplicação percebemos que muitos passaram a resolver, também os problemas de porcentagem.

\section{Tabela 6 - Comparativo da turma B - Antes e Depois da WQ}

\begin{tabular}{|l|l|l|}
\hline & ANTES & DEPOIS \\
\hline Média & 4,0235 & 8,6941 \\
\hline Mediana & 3,9000 & 8,9000 \\
\hline Desvio Padrão & 2,84595 & 1,46393 \\
\hline Mínimo & 0,00 & 4,30 \\
\hline Máximo & 8,90 & 10,00 \\
\hline
\end{tabular}

$\mathrm{Na}$ tabela 6 temos os dados relativos a turma B que apresentou um desempenho consideravelmente melhor em relação a turma A. Os dados referentes a primeira aplicação mostram uma heterogeneidade na turma com o mínimo, 0,00, e o máximo 8,90, é possível constatar que enquanto alguns alunos apresentavam rendimento satisfatório no conteúdo outros praticamente os desconheciam. A média de aproximadamente 4,02 seguida da mediana de 3,90, indicam que a maior parte da turma apresentava conhecimento insatisfatório na resolução de problemas envolvendo proporcionalidade e porcentagem.

Se nos atentarmos aos valores encontrados depois da utilização da WQ temos uma surpresa, uma média de aproximadamente 8,69 , e a mediana de 8,90 
evidenciando um ótimo rendimento da turma. Embora ainda apresente um mínimo de 4,30, alguns alunos responderam corretamente a todos os itens.

Nota-se que a turma B teve um crescimento maior se comparado ao da turma A. A falta de conhecimentos prévios dos alunos da primeira turma pode ter impedido a sistematização da resolução do cálculo de porcentagens ou mesmo do entendimento dos problemas propostos na lista de exercícios.

A melhora no desempenho dos 29 alunos após a aplicação da WQ também pode ser percebida nas figuras 15 e 16 .

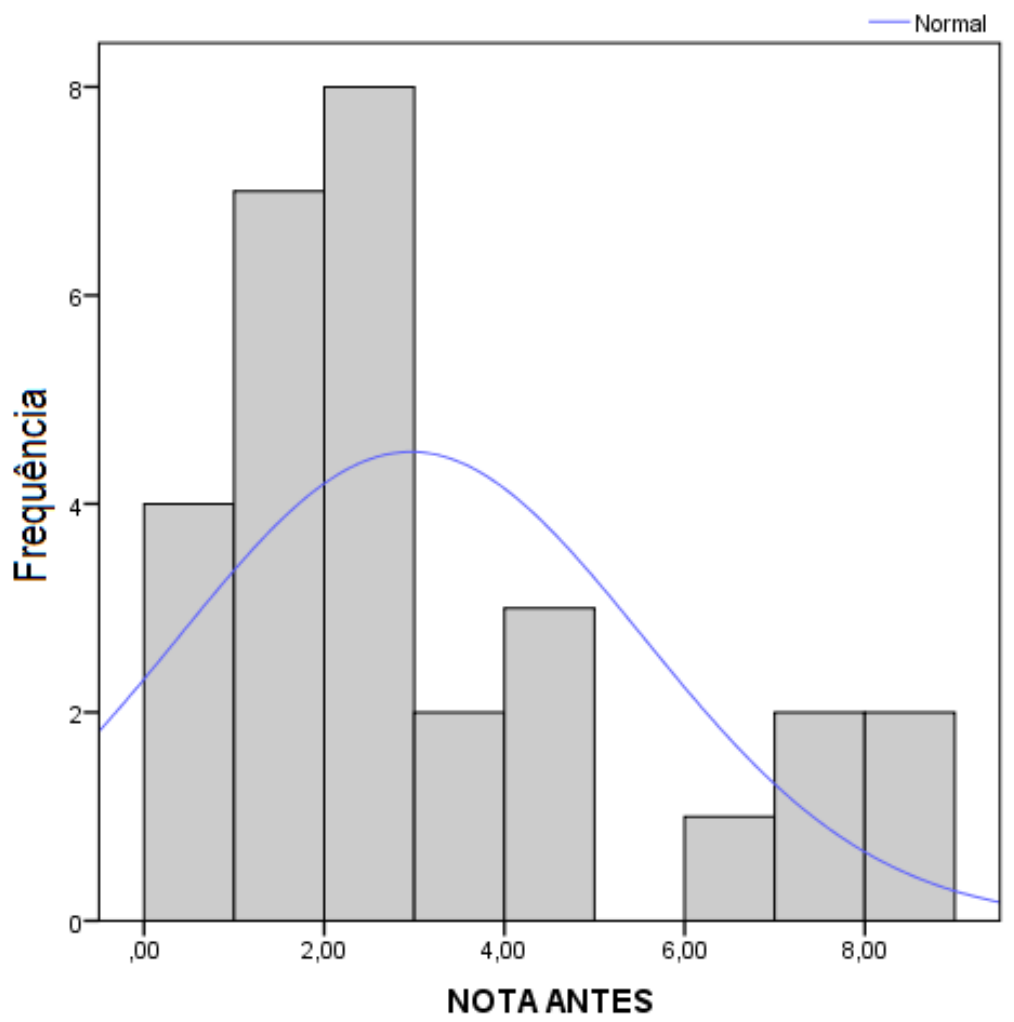

Figura 15 - Histograma das notas antes da aplicação da WQ

Na Figura 15 a curva normal está assintótica à esquerda o que evidencia uma tendência às notas mais baixas. De modo geral os alunos desconheciam ou tinham pouca familiaridade com os conteúdos, apenas 5 acertaram mais de 7 itens dos 14 presentes na lista. A grande maioria, 24 alunos, não conseguiu resolver sequer metade dos exercícios propostos, a maioria resolvia os itens de proporcionalidade e 
um ou dois itens de porcentagem por se tratarem de valores repetidamente utilizados, como $50 \%$ de um valor relacionando-o com a metade do valor.

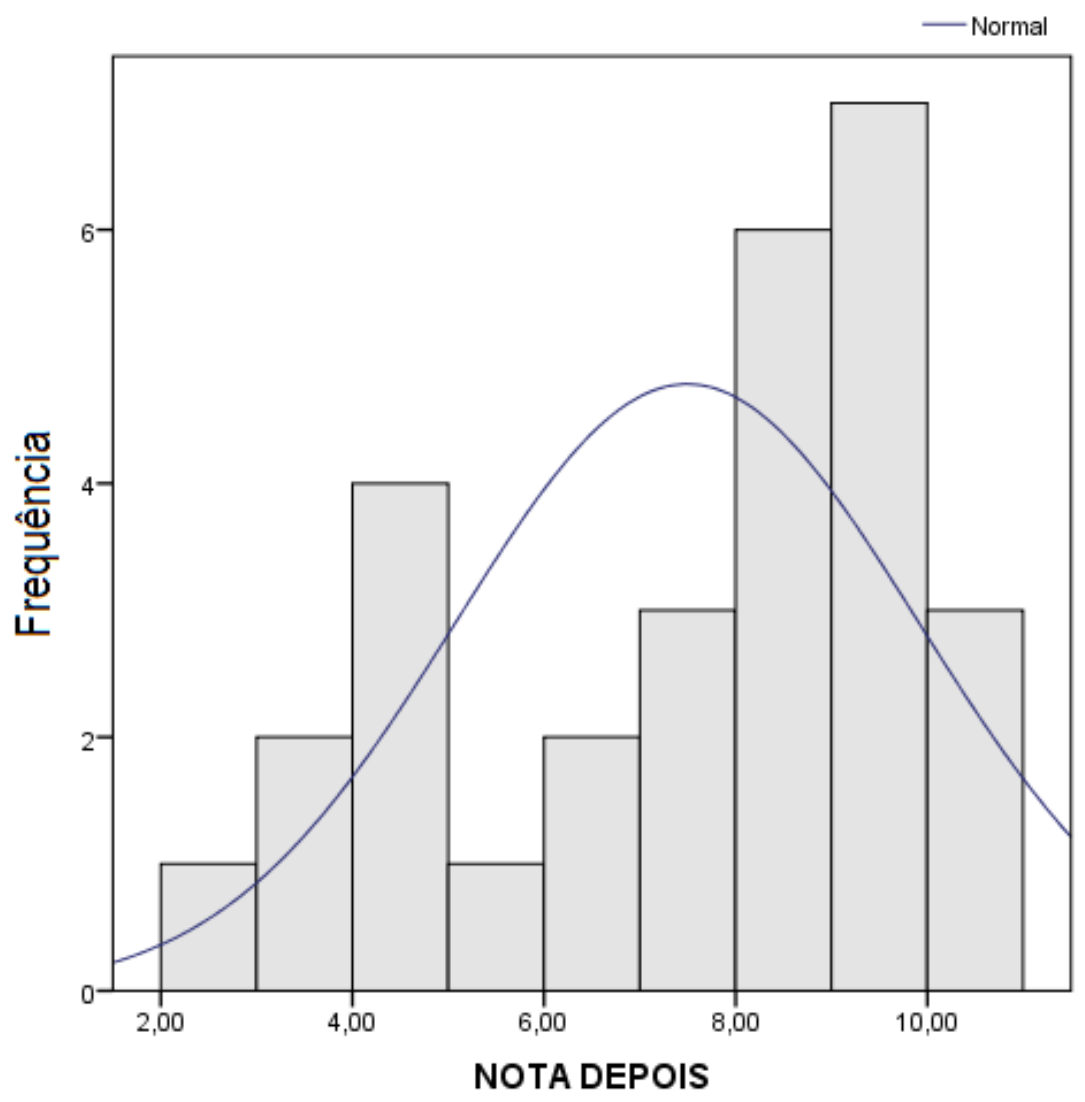

Figura 16 - Histograma das notas depois da aplicação da WQ

Após a aplicação da WQ vemos na Figura 16 que a curva normal é assintótica à direita revelando uma tendência às notas mais altas. A maior parte dos alunos obteve uma nota maior do que 5, e 16 alunos apresentaram nota maior ou igual a 8 , o que somente seria possível respondendo corretamente as questões que envolviam porcentagem.

Acredito que encontramos aqui evidências de que a metodologia se mostrou eficaz na revisão desses conteúdos e em auxiliar os alunos a formularem estratégias para resolver os problemas. 


\section{Tabela 7- Comparativo das medidas dos 29 alunos antes e depois da aplicação da WQ}

\begin{tabular}{|l|l|l|}
\hline & ANTES & DEPOIS \\
\hline Média & 2,9621 & 7,4931 \\
\hline Mediana & 2,1000 & 8,6000 \\
\hline Desvio Padrão & 2,57147 & 2,41852 \\
\hline Mínimo & 0,00 & 2,10 \\
\hline Máximo & 8,90 & 10,00 \\
\hline
\end{tabular}

Quando juntamos as duas turmas, observamos um crescimento nas medidas de tendência central: a média subindo de 2,96 para 7,49, e a mediana de 2,10 para 8,60 , indicando que a grande maioria dos alunos apresentou uma boa resposta a metodologia.

Embora o desvio padrão tenha se mantido praticamente o mesmo, por volta de 2,50, um número alto e que indica haver uma variação considerável entre os conhecimentos desses alunos.

É interessante notar que os alunos apresentaram uma resposta muito boa à situação de aprendizagem no que diz respeito a construção do conceito de porcentagem e proporcionalidade, conteúdos chave da lista de exercícios e de grande importância para a continuidade no entendimento de temas relacionados a Matemática Financeira, Funções, Geometria, no entendimento de gráficos e a resolver problemas do dia a dia que na maioria das vezes não passam de "regras de três".

Chamou atenção o fato de que mesmo sem realizarem listas de exercícios repetitivos, os alunos, ainda assim indicam ter sistematizado os métodos de resoluções trabalhados de maneira estimulante e dinâmica no decorrer da aplicação da WQ. 


\section{Análise Qualitativa dos exercícios}

O exercício 1 visava a aplicação direta do cálculo de porcentagens. Como pode ser observadodo na Figura 17, o grau de dificuldade é crescente, porém a maioria dos valores facilita o cálculo, excetuando-se os dois últimos itens que avaliam também os cálculos que envolvem números decimais.

1. Encontre os valores abaixo:
a) $50 \%$ de 200
b) $25 \%$ de 300
c) $30 \%$ de 500
d) $12 \%$ de 250
e) $75 \%$ de 120
f) $2,5 \%$ de 210

Figura 17 - Questão 1 da lista de exercícios da tarefa 4.

Foi notável a diferença entre as aplicações antes e depois das aulas com a WQ. O aluno A11b2013 apresentava na primeira aplicação total desconhecimento em relação ao cálculo de porcentagem como pode ser visto no extrato (Figura 18). O aluno buscou a estratégia de dividir o número pela porcentagem que deveria ser calculada, mostrando que não entendia o conceito de porcentagem. 


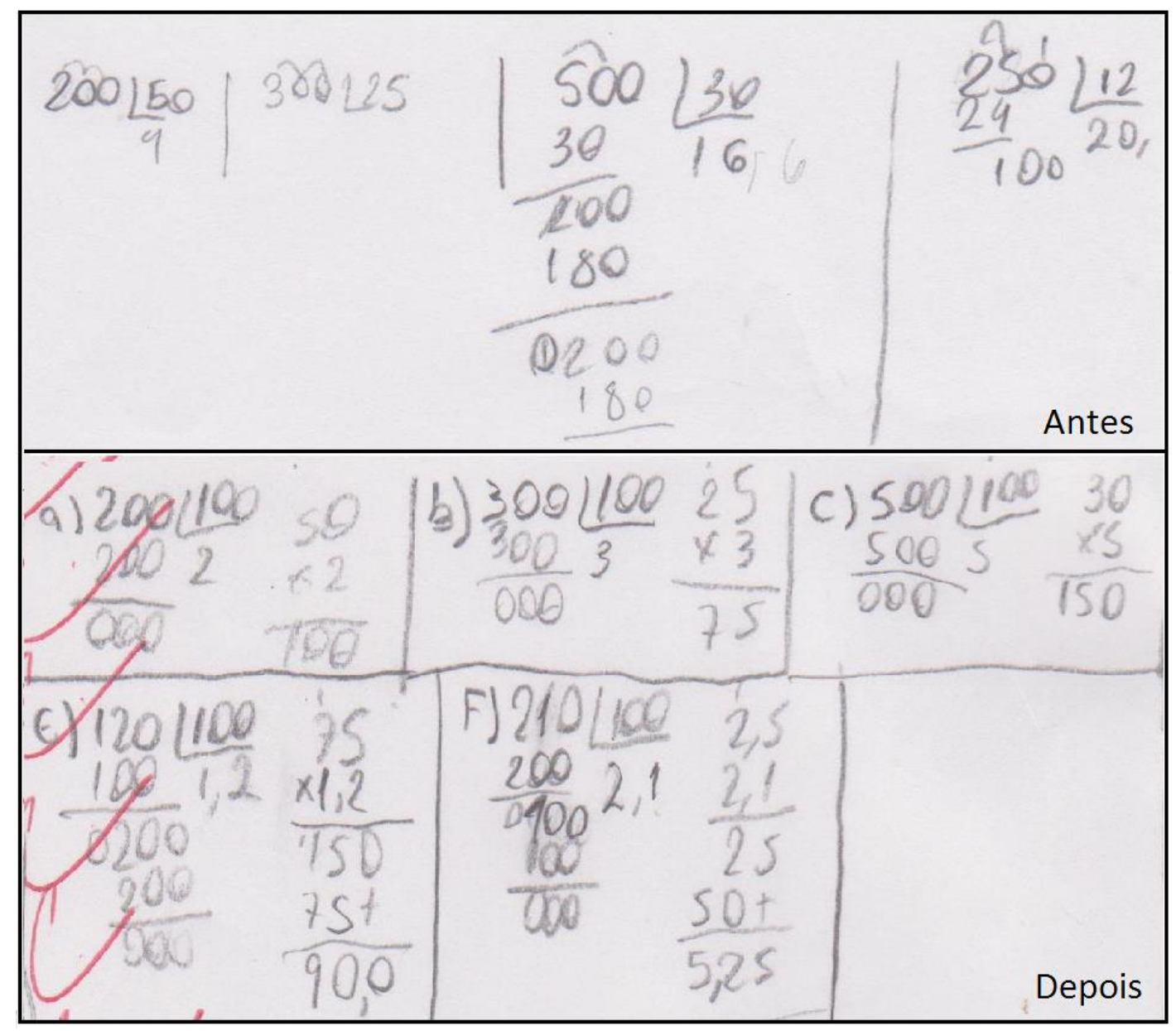

Figura 18 - Extrato dos protocolos do aluno A11b2013, exercício 1 da Tarefa 4, antes e depois da WQ

Depois da aplicação da WQ o aluno apresentou todos os cálculos corretos. O método utilizado foi o mesmo apresentado pela WQ: divide o número por 100 e em seguida multiplica o resultado pela porcentagem desejada. $O$ aluno, que na primeira aplicação resolveu somente os problemas envolvendo proporcionalidade e multiplicação, na segunda resolveu todos os problemas de porcentagem também, com apenas um erro na questão 4 a qual discutiremos oportunamente.

A maior parte dos alunos não teve problemas em resolver os 4 primeiros itens da questão 1 depois da WQ, porém o mesmo não aconteceu com os dois últimos, principalmente pelo posicionamento da vírgula nos resultados, o que parece indicar uma dificuldade no algoritmo e não no conceito ou na utilização do método. A figura 
19 apresenta a resolução, depois da WQ, do aluno A4a2013, que na primeira aplicação deixou a questão em branco.

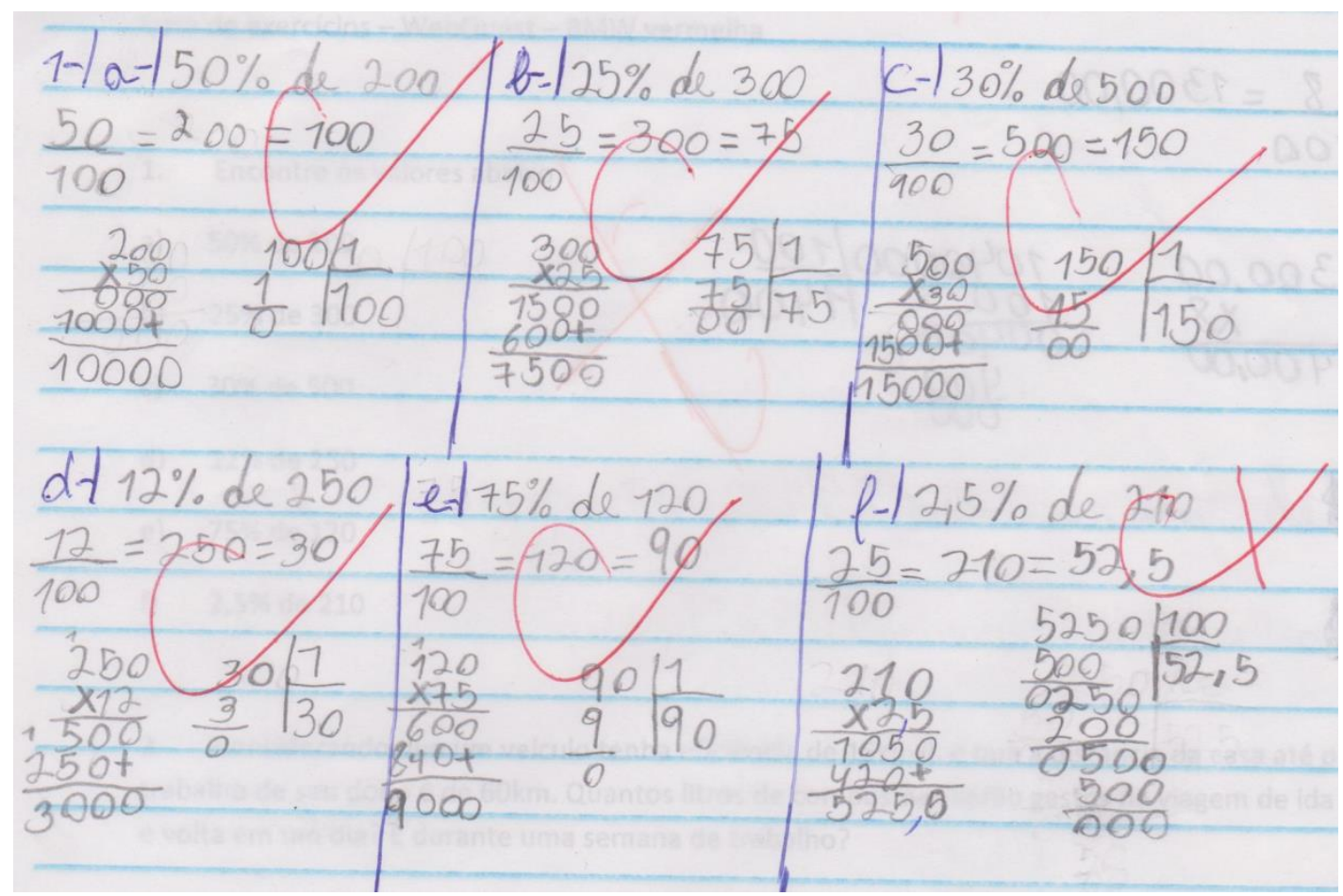

Figura 19 - Extrato do protocolo do aluno A4a2013, exercício 1 da Tarefa 4 em 2013

É possível notar que seu erro, como o de outros colegas, esta relacionado a dificuldade que os alunos apresentam ao operar números decimais, fazendo sempre confusão quanto a posição da vírgula. Nesse caso o aluno confundiu-se na hora de realizar a divisão por 100, conceito já trabalhado pelo professor com a metodologia tradicional com essas turmas. Outro fato interessante na Figura 19 é o erro quanto a representação das operações que $\mathrm{o}$ aluno pretende fazer, a notação $\frac{50}{100}=200=$ 100 apresenta um erro ao utilizar o primeiro sinal de equivalência o correto seria $\frac{50}{100} \cdot 200=100$, ainda assim, como os resultados estão corretos, o item foi considerado correto. 
Esse erro de notação pode estar associado à pouca repetição dos exercícios para que os alunos fixem os algoritmos e também a linguagem adequada. Embora pudesse evidenciar um desconhecimento dos alunos quanto às operações a serem executadas percebe-se, pelos cálculos apresentados, que o aluno tem um bom domínio do algoritmo utilizado deixando a desejar somente no tocante a representação através dos símbolos matemáticos. Diante disso fica a reflexão para que se tomem os devidos cuidados para se equilibrar os exercícios a fim de que os alunos se apropriem também da linguagem matemática a ser utilizada.

A partir da análise dos extratos de todos os alunos pudemos perceber que os mesmos apresentaram apenas dois tipos de algoritmos, ou os alunos dividiram a quantidade total por 100 e depois multiplicaram pelo valor da porcentagem a ser calculada ou na ordem inversa, primeiro multiplicaram o total pela porcentagem a ser encontrada e em seguida dividiram por 100.

Era esperado que esses fossem os algoritmos utilizados, uma vez que o material de consulta disponível na aba Processo da WQ trazia o cálculo da porcentagem como a multiplicação da fração centesimal pelo valor total.

As duas representações encontradas são descritas em Castro Filho (1995) e foram por ele denominadas de Multiplicação seguida de divisão por cem e Multiplicação por número racional, representando assim a porcentagem como um operador racional. A idéia de porcentagem como um operador racional encontra suporte em Imenes e Lellis (2005) entendendo que essa é a maneira como as pessoas calculam porcentagem no dia a dia.

O exercício 2 era o primeiro problema da lista, e buscava verificar se os alunos eram capazes de reproduzir os cálculos trabalhados na WQ, com um problema muito parecido ao realizado durante o preenchimento da tabela na Tarefa 2 da $W Q$, como pode ser visto na figura 20 . 
2. Considerando que um veiculo tenha eficiência de $15 \mathrm{~km} / \mathrm{l}$, e que a distância da casa atè o trabalho de seu dono é de $60 \mathrm{~km}$. Quantos litros de combustivel serão gastos na viagem de ida e volta em um dia? E durante uma semana de trabalho?

\section{Figura 20 - Questão 2 da lista de exercícios da Tarefa 4}

Essa foi a questão que mais apresentou acertos nas duas aplicações por se tratar de um racíocinio que depende mais da lógica e da proporcionalidade e os alunos apresentavam maior domínio desse conceito e dos cálculos necessários para se resolver o problema, além de representar um problema que acabara de ser explorado de maneira semelhante na WQ.

Várias estratégias foram utilizadas para a resolução desse problema como podemos perceber nos extratos apresentados na Figura 21 em que A7a2013, embora apresente um erro quanto à representação das operações ao escrever 4+4 $=8 \times 5=40$, encontra como resposta final o resultado correto para o problema. Para resolver, o aluno primeiro dividiu a distância pela eficiência do veículo encontrando a quantidade de litros de combustível requerida para a ida e depois somou esse valor a ele mesmo obtendo o gasto de combustível diário e finalmente multiplicou por 5 dias para obter o gasto semanal.

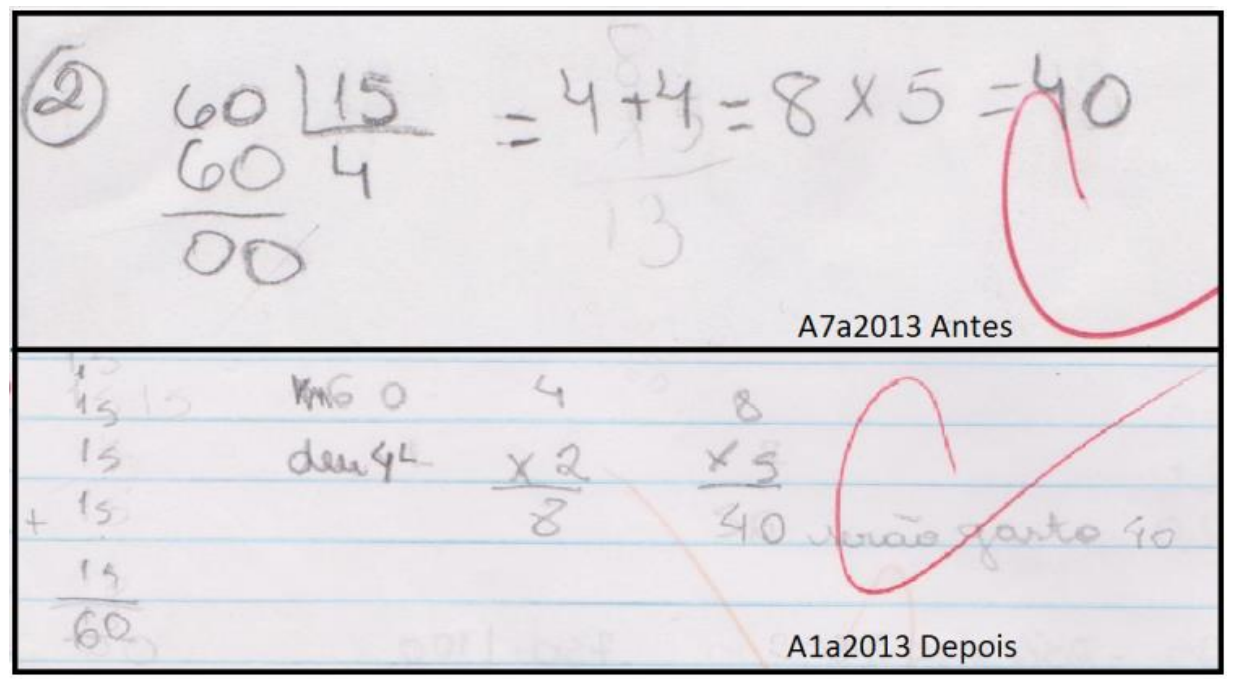

Figura 21 - Extrato do protocolo dos alunos A7a2013 e A1a2013. 
Já o aluno A1a2013 somou o valor 15 referente a quantidade de quilômetros que o carro se desloca utilizando um litro de gasolina e percebeu que após somá-lo 4 vezes teria se deslocado $60 \mathrm{Km}$, ou seja, identificou que seriam gastos 4 litros de combustível e em seguida realizou os mesmos cálculos, multiplicando por 2 para obter o consumo diário e em seguida por 5 para o consumo semanal, evidenciando que comreendera a situação problema.

O aluno A16b2013 que sempre teve um ótimo rendimento em matemática e por isso assimila procedimentos de maneira mais eficiente, utilizou a regra de três logo na primeira aplicação (Figura 22).

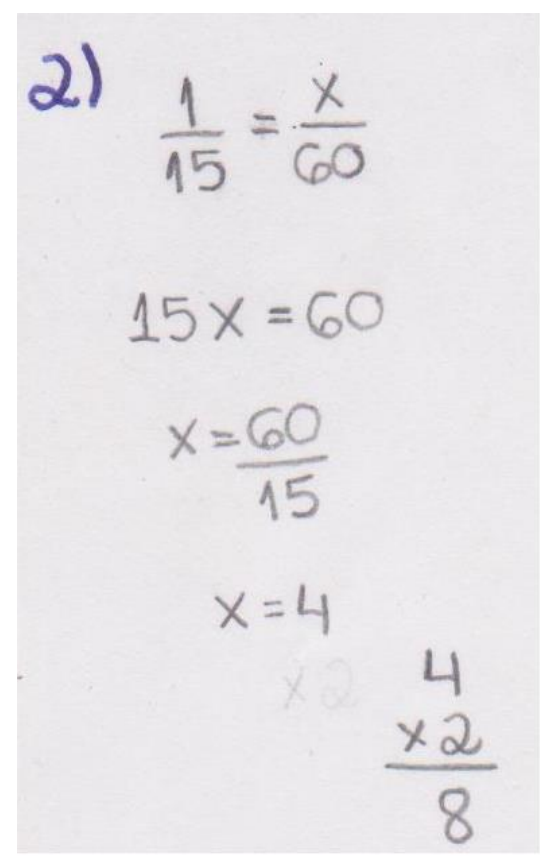

Figura 22 - Extrato do protocolo do aluno A16b2013 antes.

Como a proporcionalidade havia sido trabalhada com os alunos há pouco tempo em sala de aula, apesar de utilizarem estratégias variadas a maioria conseguiu resolver satisfatoriamente a questão, apresentando apenas erros quanto a representação das operações realizadas. 
Dos 43 alunos que entregaram a lista para correção, somente 5 alunos, que apresentavam um déficit grande de aprendizado, não chegaram às respostas corretas ou nem ao menos tentaram resolver.

Cabe lembrar que em todo conselho final é discutida a retenção desses alunos, mas a equipe gestora sempre pressiona os professores para que os alunos sejam aprovados, o que em minha opinião é lamentável visto que os alunos ficam por vezes perdidos em sala de aula pois não dominam sequer as quatro operações básicas com números naturais.

No problema 3 era esperado que, realizando multiplicações de números decimais, os alunos chegassem ao resultado de quanto um trabalhador gastaria em um mês para realizar as viagens, como se observa na Figura 23.

3. De acordo com a questão 2 , qual seria o gasto mensal com as viagens se o preço médio do combustivel é R\$2,75? (considere 22 dias úteis no mês)

Figura 23 - Questão 3 da lista de exercícios da Tarefa 4.

Essa foi uma questão com bastante acerto na segunda aplicação muito provavelmente por se tratar de um conteúdo exaustivamente trabalhado anteriormente pelo professor com as turmas em sala de aula. Mesmo com a maioria respondendo certo, alguns alunos não tinham a menor noção de como resolver na primeira aplicação, como é o caso da aluna A14a2013, mas que apresentaram uma resolução correta na segunda aplicação, parecendo evidenciar que a situação de aprendizagem contribuiu na revisão de conteúdos trabalhados pelo professor utilizando outras metodologias. A figura 24 ilustra essa diferença. 


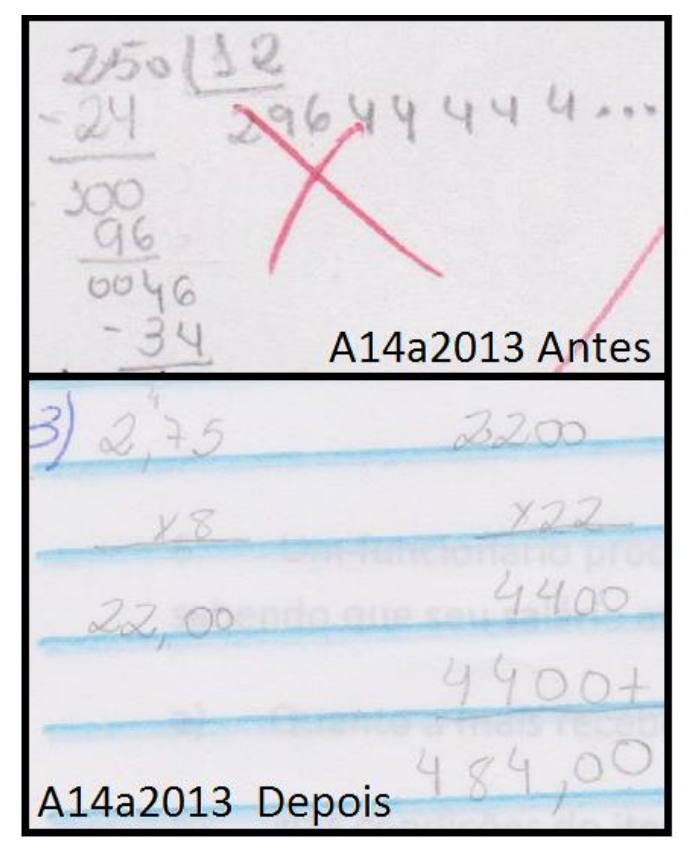

Figura 24 - Extrato do protocolo da aluna A14a2013.

Os números utilizados pela aluna na primeira aplicação não fazem referência aos dados do problema. A aluna parece ter escrito a resolução, ainda que errada, do item d do exercício 1 da mesma lista, onde era esperado o cálculo de $12 \%$ de 250. Na segunda aplicação a aluna, sabendo que seriam gastos 8 litros de combustível por dia e que o litro do mesmo custava $R \$ 2,75$ multiplicou os valores obtendo o valor gasto diariamente $\mathrm{R} \$ 22,00$ em seguida multiplicou o gasto pelo número de dias úteis de acordo com o enunciado, totalizando $\mathrm{R} \$ 484,00$.

A partir da questão 4 os problemas envolviam o cálculo de porcentagem e o tema central continuava sendo o deslocamento e os gastos envolvidos. No problema 4 (Figura 25) esperava-se que o aluno conseguisse aplicar o cálculo de porcentagem de um valor, cálculo esse realizado durante a WQ ao se calcular o valor do IPVA e do seguro de cada modelo. 


\section{Levando em conta a questão 3 , quanto seria desembolsado pelo trabalhador se seu empregador se prontificou a custear $80 \%$ dos custos com viagens?}

\section{Figura 25 - Questão 4 da lista de exercícios da tarefa 4.}

É possível notar na Figura 25 que embora o cálculo a ser realizado fosse a porcentagem, o aluno deveria perceber que ao calcular $80 \%$ estaria calculando o valor a ser pago pelo patrão e a questão solicitava quanto deveria desembolsar o trabalhador, ou seja, ele deveria calcular os $80 \%$ e subtrair do valor total, ou poderia calcular $20 \%$ obtendo de imediato o valor questionado.

Todos os que resolveram corretamente utilizaram o primeiro método, na verdade somente um aluno relacionou o valor a ser desembolsado com a porcentagem de $20 \%$ mas não realizou os cálculos para chegar a um valor que levasse em conta o resultado obtido na questão 3.

Nos extratos da Figura 26 temos a questão resolvida corretamente e outra solução na qual o aluno não percebeu que deveria calcular o valor desembolsado pelo trabalhador e não pelo empregador.

O interessante é notar que o primeiro aluno A18a2013 sempre apresentou dificuldades com matemática e também mau comportamento dentro de sala de aula, porém ele demonstrou que quando aprende os cálculos e se empenha na resolução consegue interpretar e responder as questões. Já o segundo aluno A15b2013, ótimo aluno em sala, dedicado e estudioso, acabou errando possivelmente por uma falta de atenção. 


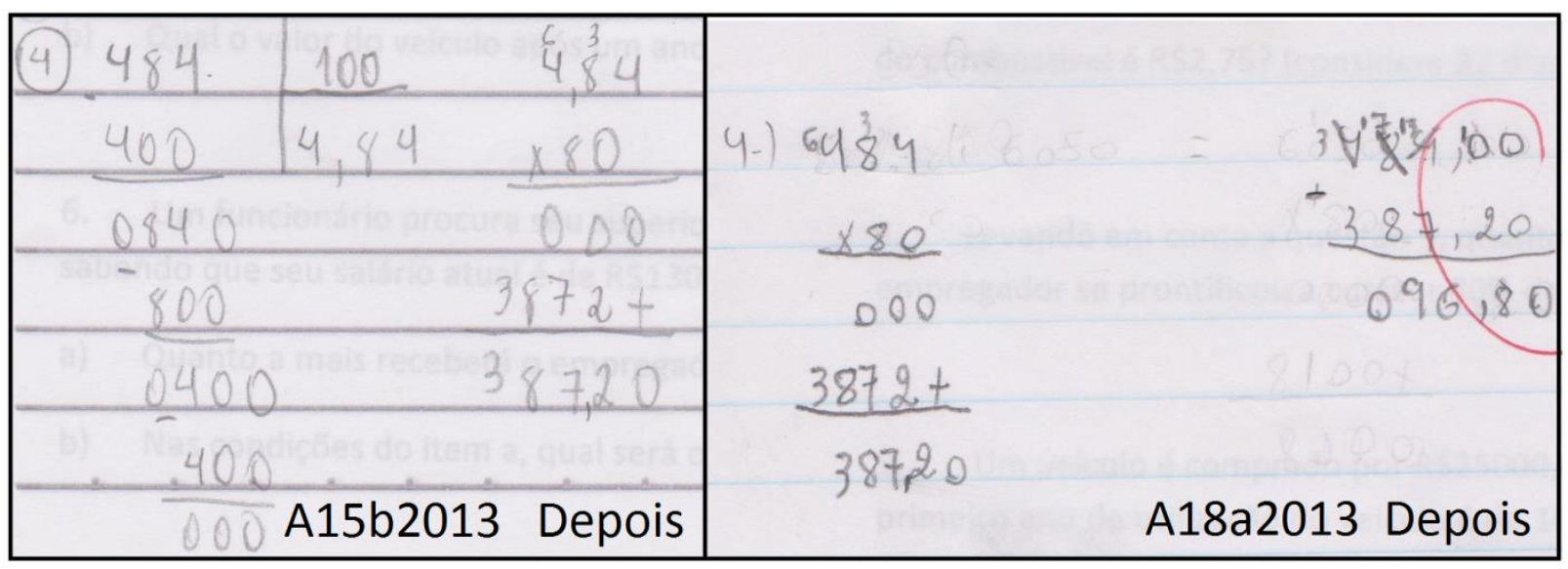

Figura 26 - Extrato dos protocolos dos alunos A18a2013 e A15b2013.

De todo modo foi satisfatório o aproveitamento das turmas nesta questão e chamou atenção a melhora na resposta dos alunos que estavam motivados, chegando a surpreender em alguns casos, principalmente se comparados à outros problemas, muitas vezes mais simples, que haviam sido propostos pelo professor durante $\mathrm{o}$ ano letivo. Quando os problemas eram propostos após uma aula tradicional os alunos muitas vezes não liam o problema e logo vinham pedir para que o professor lesse e ajudasse a interpretar, barreira que foi quebrada com a aplicação da WQ, indicando, novamente, que essa metodologia pode ser uma forte aliada no desenvolvimento da autonomia do educando, principalmente por motiválos e fazê-los sentirem-se capazes.

Focando a desvalorização anual de um automóvel a questão 5 (Figura 27) exigia um maior cuidado nos cálculos devido ao valor de porcentagem a ser calculado no item a, $16,8 \%$ de $\mathrm{R} \$ 25.000,00$.

5. Um veículo é comprado por $\mathrm{R} \$ 25000,00$, sabendo que a desvalorização média no primeiro ano de utilização do veiculo é de $16,8 \%$, responda:

a) Quanto desvalorizou esse carro após um ano de uso?

b) Qual o valor do veículo após um ano de uso?

Figura 27 - Questão 5 da lista de exercícios da Tarefa 4. 
Alguns alunos erraram a posição da vírgula, demonstrando um erro noo algoritmo mas não no conteúdo estudado. A aluna A1a2013 cometeu o erro nos dois itens, possivelmente pela confusão com as vírgulas do nosso sistema monetário, como se vê na Figura 28:

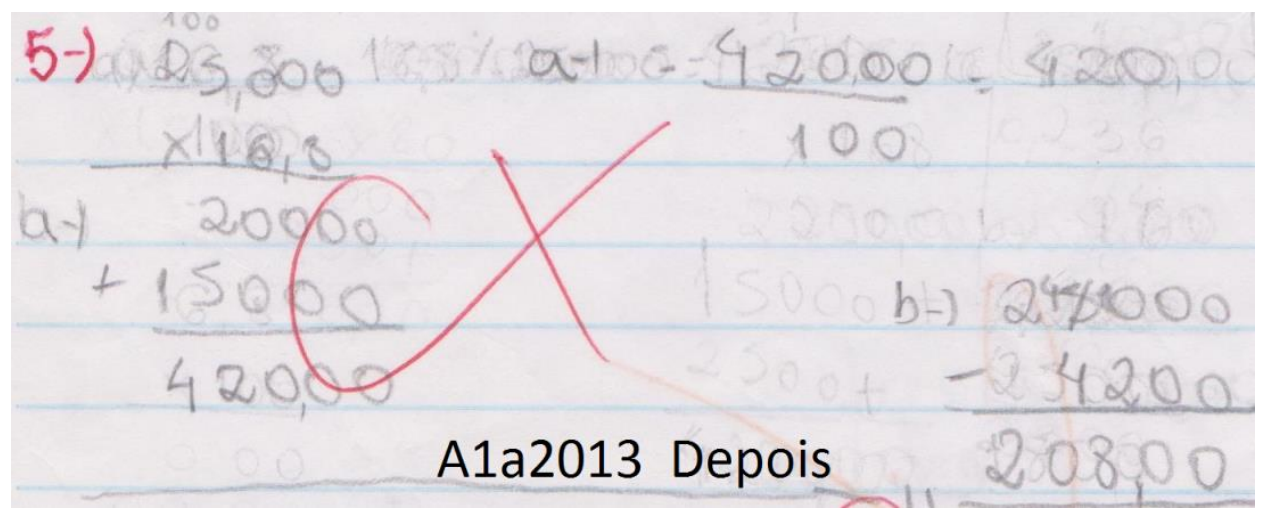

Figura 28 - Extrato do protocolo do aluno A1a2013

Após calculado o item a era necessário que o valor fosse descontado do valor inicial do carro, chegando a um novo valor depois de um ano de uso. Na primeira aplicação de 2013 a maioria dos alunos errou essa questão porém, principalmente no que se refere a turma $B$, houve um aumento expressivo no número de acertos na segunda aplicação. Na primeira, a maioria deixou a questão em branco. Ao levarmos em conta que a lista não foi corrigida entre uma aplicação e outra e que o conteúdo foi trabalhado somente através da WQ, podemos concluir que atividade auxiliou os alunos quanto a capacidade de resolver problemas que envolvam o cálculo de porcentagem.

O aluno A20a2013 que havia errado na primeira aplicação acertou na segunda, porém o índice de acerto na turma A não foi satisfatório nem mesmo na segunda aplicação. Dada a maneira como foi feita a divisão das turmas separando os alunos por desempenho, a turma A ficou com um grupo onde a maioria dos alunos apresentavam grande dificuldade na leitura e interpretação de textos e também no que se refere a realização de cálculos e memorização dos métodos. 0 
aluno A20a2013, era o representante de classe e um dos que apresentava o menor déficit entre os alunos da turma.

Após a $2^{a}$ aplicação, essa questão foi corrigida na lousa e o professor salientou que a desvalorização poderia ser considerada um gasto, e através de exemplos lembrou aos alunos que quanto mais caro o carro, mais ele se desvaloriza. Considero importante no momento da correção propor questionamentos buscando dar maior sentido aos números calculados.

Embora a resolução da questão 6 (Figura 29) se assemelhe a questão 5, superou a anterior em números de acertos, principalmente na segunda aplicação.

6. Um funcionário procura seu superior com a intenção de pedir um aumento de salário, sabendo que seu salário atual é de $\mathrm{R} \$ 1300,00$, responda:

a) Quanto a mais receberá o empregado se conseguir $8 \%$ de aumento?

b) Nas condições do item a, qual será o seu novo salário?

Figura 29 - Questão 6 da lista de exercícios da Tarefa 4.

A aluna A1a2013 que apresentou cálculos errados na questão 5 dessa vez acertou o posicionamento da vírgula. Nessa questão os números eram mais simples, facilitando os cálculos, o que nos ajuda a perceber que o conteúdo foi assimilado pela aluna porém a mesma apresenta dificuldades no cálculo com números decimais.

\section{$\frac{140400}{1404002013 \quad \text { Depois }}$}

Figura 30 - Extrato do protocolo da aluna A1a2013 
Novamente podemos perceber no extrato da aluna o erro quanto a representação que como já dito anteriormente provavelmente é derivado da maneira como os alunos utilizaram os algoritmos de resolução durante a WQ. Os alunos utilizaram a calculadora do computador e poucas duplas registravam os cálculos em algum papel. Embora tenha sido sugerido pelo professor que os alunos levassem ao laboratório papel, lápis e caneta não foi pedido aos alunos que registrassem os cálculos durante a atividade. Ou seja, durante a revisão do conteúdo os alunos não escreviam seus algoritmos apenas aplicavam o algoritmo que haviam estudado com o auxilio da calculadora.

Diante dos erros quanto ao uso da linguagem matemática, que infelizmente somente foi verificada após a aplicação, uma alternativa seria pedir aos alunos que registrassem os algoritmos e os cálculos mesmo que utilizassem a calculadora durante a atividade. A utilização e reconhecimento da linguagem matemática por parte dos alunos é parte importante do aprendizado do aluno auxiliando-o a memorizar tais procedimentos para que possa aplica-los futuramente.

Embora alguns alunos não tenham apresentado grande melhora, a maioria conseguiu resolver um maior número de exercícios na segunda aplicação, o que pôde ser percebido pelos gráficos, tabelas e extratos apresentados no decorrer da análise. Os resultados são ainda melhores ao levarmos em consideração que esses alunos estavam acostumados a realizar inúmeras repetições dos cálculos para que pudessem memorizá-los e dessa vez eles não tiveram essa chance.

Cabe salientar que cada educando se adapta melhor a uma metodologia, nem tudo que estimula um, estimula a todos, logo o melhor em minha opinião é intercalar as metodologias. Embora memorizar não seja mais sinônimo de conhecer, não deixa de ser uma habilidade útil e necessária no dia a dia. Portanto não devemos abolir as listas de exercícios e muito menos podemos achar que memorizar 
basta. A busca pelo equilíbrio e pela alternância nas metodologias e no foco de cada aula pode garantir o sucesso no processo de ensino-aprendizagem.

\section{Análise da Metodologia WebQuest}

O primeiro ponto a ficar claro foi que para que o foco da aula fosse o aluno era, embora não suficiente, necessário que o professor fosse o foco da mudança dentro de sala.

Ora, não é suficiente uma vez que a aula por si só representa uma atividade intencionada do professor e que depende de fatores como infraestrutura, conhecimentos prévios dos alunos, burocracias, regras disciplinares e tantos outros que podem dificultar para que essa mudança ocorra ou que uma aula aconteça como foi prevista, porém, mostra-se necessária pois se o professor não alterar sua prática, o foco permanecerá na exposição do conteúdo quando deveria ser na atividade a ser desenvolvida pelo aluno, observando-o e identificando suas dificuldades, auxiliando nas suas dúvidas, instigando a reflexão mas deixando espaço para que o educando atue.

Tanto quanto a inserção das TICs em sala de aula, uma nova metodologia de ensino exige um novo professor. A metodologia por si só não garante mudança na sala de aula.

Um exemplo dessa mudança pôde ser observado logo nos primeiros dias de aplicação se comparados às aulas regulares. Durante atividades em sala de aula no método tradicional, depois de "transmitir" o conteúdo e fazer exemplos na lousa, enquanto os alunos realizavam exercícios de fixação do conteúdo, o professor transitava pela sala observando os trabalhos e tirando eventuais dúvidas.

Em muitos casos, principalmente quando o aluno apresentava um déficit de aprendizagem em matemática, era necessário que o professor realizasse, a pedido 
do aluno, de maneira individualizada, a resolução de um exemplo em seu caderno e somente depois o aluno procurava resolver sem a ajuda, ainda assim incentivado pelo professor.

Com a nova metodologia não foi muito diferente nos primeiros dias de aplicação em 2012: como já relatado os alunos solicitavam que o professor estivesse ao seu lado durante a realização da atividade, o que certamente não favoreceria o desenvolvimento da autonomia. Contudo é possível afirmar que a WQ motivou os alunos a realizarem as tarefas e a entrar em contato com um conteúdo matemático do qual sempre reclamavam, porcentagem, e as intervenções do professor foram no sentido de orientar os alunos a como proceder para a resolução acompanhando o que estava descrito na aba Processos da WQ.

Era comum que os alunos perguntassem logo que o professor entrava na sala se iriam para o laboratório terminar as atividades, o que nem sempre era possível por não haver horário disponível para a utilização do laboratório ou porque muitos alunos haviam faltado.

A negativa do professor era sempre seguida de descontentamento dos alunos que se mostraram, em sua maioria, contentes e dispostos a realizarem as atividades. Se a resposta fosse afirmativa, o professor não enfrentava problemas de organização para que os alunos se dirigissem ao laboratório. A conversa explicando como e o porque realizariam essa sequência de aprendizagem refletiu em mudanças de atitude e comportamento no decorrer da atividade.

Outro fato que nos ajuda a identificar a motivação dos alunos é que mesmo sabendo que teriam tempo para realizar as tarefas durante os horários de aula, alunos que haviam faltado em alguma aula, quando possível, realizavam as atividades atrasadas como tarefa de casa e alguns, mesmo não faltando, adiantavam em casa e tiravam as dúvidas com o professor na outra aula. 
A motivação refletia diretamente na disciplina da turma. A ideia de colocar o conteúdo como uma ferramenta para resolver um problema do cotidiano fez com que os alunos se dedicassem mais na realização das atividades e como o tempo da aula ficava curto, não havia espaço para conversas paralelas.

No ano de 2013 nenhum ato de indisciplina foi percebido, muito pelo contrário, foi notável a mudança de comportamento, principalmente dos alunos da $8^{a}$ A. As turmas do ano letivo de 2013 foram separadas de acordo com o rendimento e a disciplina dos alunos, ficando a 8 ${ }^{\mathrm{a}} \mathrm{A}$ com os que apresentavam maior dificuldade e pior comportamento. Logo no primeiro dia de aplicação da WQ houve um problema no áudio do computador que projetava o curta metragem, o som estava bem baixo, mas devido a atenção e disciplina dos alunos todos conseguiram assistir e entender o vídeo.

Isso representou uma grande mudança de atitude uma vez que muitas vezes em sala de aula ou durante um vídeo era necessário interromper a aula devido a conversas ou mesmo alunos transitando pela sala. A única vez que o professor precisou ser enérgico com algumas alunas foi devido às mesmas estarem trocando informações entre as duplas, o que foi percebido pelo monitor do laboratório através do sistema Blue Control.

Vale salientar que a maior cumplicidade entre os alunos de 2013 para com o professor acredita-se, deve-se, principalmente, ao fato de uma maior convivência com o professor e a uma conversa prévia deste com os alunos alertando-os que os resultados não seriam sempre os mesmos então deveriam se concentrar em resolver suas próprias atividades.

Em 2012 no estudo piloto eram 17 duplas e 1 aluno realizando a atividade sozinho, desses, 5 duplas e o aluno, apresentaram dados copiados de outras tabelas enquanto 9 duplas apresentaram todos os dados da tabela corretamente. 
Em 2013, na presente pesquisa eram 22 duplas e 3 alunos individualmente, sendo que apenas 2 duplas preencheram com dados de outras tabelas e 11 preenchimentos estavam totalmente corretos.

Esses dados parecem evidenciar que a atividade foi melhor conduzida em 2013 e que mesmo havendo troca de informação entre algumas duplas, o número foi pequeno se comparado às duplas que realizaram com perfeição o preenchimento da tabela.

Além das pesquisas citadas que tem como metodologia a WQ muito do que foi vivenciado durante as atividades realizadas durante essa pesquisa nos mostra que é possível ensinar matemática com a utilização de WQ. 


\section{Considerações finais}

Para que o professor atinja o objetivo de ser um mediador no processo de ensino/aprendizagem é preciso, além de dominar as tecnologias que farão parte do projeto, planejar, executar, revisar e avaliar cuidadosamente sua aula.

Nesse sentido essa pesquisa teve como objetivo geral analisar o uso da metodologia de ensino - WebQuest - em duas turmas de alunos do nono ano do Ensino Fundamental de uma escola pública estadual do interior do Etsado de São Paulo. Para a realização da pesquisa, 47 alunos foram submetidos a uma intervenção utilizando uma WQ construída pelo professor/pesquisador.

A pesquisa buscou atingir três objetivos específicos. O primeiro deles foi: Identificar fatores no uso da WebQuest que podem contribuir para a aprendizagem de porcentagem.

A análise dos dados mostrou que a metodologia provoca mudanças no comportamento dos alunos no que diz respeito a concentração e o desejo em aprender o conteúdo, o que vem a indicar uma grande potencialidade de uso em revisões de conteúdo. Se bem planejada, a atividade pode deixar de ser uma repetição podendo ser uma maneira de apresentar novos significados aos temas revistos e promover a interdisciplinaridade.

Acredito que através da experiência vivenciada, os alunos em um trabalho conjunto, coletando e organizando as informações do problema, mesmo que sejam informações previamente selecionadas pelo professor, agiram na busca da informação, estavam em ação constante, não passivos a copiar.

Na maioria dos casos a dupla deveria decidir após uma conversa as ações, inclusive quem ia estar no controle do mouse ou do teclado. Situações de motivação que também geram conflitos e o professor deve estar preparado para lidar com elas. 
Em seguida, instigados pela curiosidade em saber "quanto é necessário para manter um veículo no Brasil?", " aqui na minha cidade?" os alunos começaram a fazer cálculos na calculadoras de seus computadores.

Seria descabido utilizar um computador para realizar a atividade e proibir o uso da calculadora. O conceito não depende propriamente da destreza do aluno no cálculo, em alguns casos dificuldades no cálculo podem ser até mesmo um impedimento para se entender o conteúdo.

É comum observar alunos que entendem o conceito mas não conseguem aplicá-los pois não se sentem seguros ao realizarem os cálculos, principalmente quando estes envolvem números racionais. No caso da Tarefa 2 os cálculos realmente se apresentavam complicados com números na casa das dezenas de milhar com duas casas decimais.

Por outro lado utilizar a calculadora e não registrar os procedimentos utilizados parece ter atrapalhado alguns alunos na representação dos cálculos envolvidos. Além disso os alunos não foram submetidos a uma lista repetitiva de exercícios para fixarem os procedimentos. Nesse sentido é importante observar que os alunos, em sua maioria, conseguiram resolver a lista proposta e chegar aos valores desejados mas ainda possuiam um déficit quanto a utilização da linguagem simbólica matemática.

Essa relação com os conteúdos matemáticos, onde o aluno é o ator principal e utiliza a matemática como ferramenta para interpretar e tomar decisões, era desconhecida dos alunos. A maneira como interagiam com o problema durante a WQ era outra, e não havia tempo para dispersar a atenção, para muitos o foco era encontrar a resposta ao problema proposto.

Mesmo com as reclamações, por parte dos alunos, quanto a escrever um parecer, acredito que o mesmo foi de grande valia para a aprendizagem deles. 
Para a escrita do parecer os alunos deviam consultar os dados na tabela, entrando em contato com os valores obtidos através dos cálculos novamente e tendo a chance de perceber qualquer erro. Além disso podiam perceber a proporcionalidade e como uma diferença pequena aumenta quando repetida inúmeras vezes. Existe aqui um aprendizado muitas vezes imperceptível para o aluno mas que se apresenta significativo para a construção e aperfeiçoamento dos conceitos estudados.

Gostaria também de salientar a importância do texto por ser um espaço onde o aluno é estimulado a se expressar, pode colocar o que ele pensa a partir daquele problema, espaço muitas vezes negligenciado em outras no ensino de matemática.

No ensino com a utilização de jogos, na resolução de problemas e na modelagem matemática também encontram-se espaços para a socialização das ideias por parte dos alunos, podendo estas serem registradas e entregues aos professor ou através de um dialogo que busque um caminho para o problema prosposto.

Por fim a própria lista de exercícios que visava avaliar se os conceitos foram compreendidos e se os alunos sistematizaram a resolução de problemas envolvendo porcentagem e proporcionalidade, trazia mais do que o simples cálculo de porcentagens. Tal lista buscava dar continuidade a situação da WQ, com questões relacionadas ao transporte para o trabalho, desvalorização de veículos e negociação salarial, procurando ser estimulante e despertar o interesse do aluno.

Nosso segundo objetivo específico foi: Investigar se há melhora na resolução de problemas que envolvem porcentagem, após a realização da WQ.

A análise dos resultados obtidos pelos alunos na resolução da lista antes e depois da WQ revelou que houve um crescimento considerável na média das notas do grupo que passou de 2,96 antes da aplicação para 7,49 depois da WQ e na 
mediana que de 2,1 passou a ser 8,6 . Foi possível perceber que na turma $A$ crescimento foi menor.

Mesmo que alguns alunos que já apresentavam dificuldades antes da aplicação da WQ tenha apresentado rendimento insatisfatório,os dados obtidos evidenciaram que a WQ é uma metodologia de ensino ativa, ou seja, coloca o aluno em ação na construção do seu próprio conhecimento e na busca da resolução da situação.

Nosso último objetivo específico foi: Analisar a aplicação da metodologia de WebQuest nas aulas de Matemática em uma escola pública estadual do interior do Estado de São Paulo.

Nesse sentido, a metodologia de WQ pode ser uma boa maneira de se incluir as TICs no ambiente escolar uma vez que sugere um caminho a seguir com introdução, tarefas, processo, avaliação e conclusão, mas não limita o professor que pode escolher como desenvolver seu trabalho quanto ao tipo de atividade proposta ou mesmo como avaliar o trabalho dos alunos.

A WQ ajuda o professor a organizar a sua aula em um ambiente digital e conectado facilitando o contato dos alunos com as informações disponíveis na rede e desenvolvendo a habilidade dos próprios alunos em interpretá-las e utilizá-las. Essas características quanto a utilização das TICs na WQ corroboram o exposto por Silva, K. X. S. (2006).

Mas para que os professores conheçam e aprendam a desenvolver suas aulas com a utilização da metodologia é necessário que tenham um contato direto com a mesma, nesse sentido foi acertada por parte da comissão do IX ENEM a escolha de 3 mini-cursos com o tema.

Outro fator de destaque concordante com Cruz (2006) é o fato da WQ ter um apelo motivacional nos alunos o que pode ser percebido também em nosso trabalho. 
As atitudes dos alunos, derivadas da motivação, alteraram a maneira como os mesmos se comportaram durante a atividade se comparado às de sala de aula. Foi possível percerber mudanças quanto a participação, a autonomia e a disciplina dos alunos durante as tarefas.

Além disso a contextualização da atividade de acordo com a realidade dos alunos e relacionada a matemática financeira, parece ter motivado os alunos e consequente aumentado a participação dos mesmos nas atividades, em concordância com Castro Filho (1995), Bastos (2007), Vizolli (2006), Figueiredo (2008), Ruggiero e Basso (2003), Imenes e Lellis (2005) e sugerido por Silva, M. M. (2006). Ao propor um tema de interesse dos alunos a atividade despertou a curiosidade, força motriz do aprendizado siginificativo.

Por último, a metodologia propiciou ao docente enorme satisfação, desde sua concepção, planejamento e construção, até a aplicação e posterior análise. Fica evidente que mudanças metodológicas alteram as relações há muito tempo ultrapassadas, estabelecidas no ambiente educacional e, assim, podem contribuir a uma formação crítica e autônoma dos alunos e do professor. 


\section{Referências}

APPOLINÁRIO. F. Metodologia da Ciência: filosofia e prática da pesquisa. São Paulo: Pioneira Thomson Learning, 2006.

AZEVEDO, M. C. et al. WebQuest no ensino e aprendizagem de matemática. In: Encontro Nacional de Educação Matemática, 2013, Curitiba. Anais do XI Encontro Nacional de Educação Matemática, 2013.

BARBOSA, J. C.; SANTOS, M. A. Modelagem matemática, perspectivas e discussões. In: ENCONTRO NACIONAL DE EDUCAÇÃO MATEMÁTICA, 9, Belo Horizonte. Anais... Recife: Sociedade Brasileira de Educação Matemática, 2007. 1 CDROM

BARROS, C. B., SCHERER, S. Análise da etapa tarefa de uma webquest de álgebra que caminho seguir? In: Encontro Nacional de Educação Matemática, 2013, Curitiba. Anais do XI Encontro Nacional de Educação Matemática, 2013.

BASTOS, A. S. A. M. Noções de porcentagem, de desconto e de acréscimo na educação de jovens e adultos. 2007. 141f. Dissertação (Mestrado em Ensino de Ciências e Matemática) - Universidade Cruzeiro do Sul, São Paulo, 2007.

BOGDAN, R.C.; BIKLEN, S.K. Investigação qualitativa em educação. Porto: Editora Porto, 1994.

BRASIL. Alexandre F. Barbosa. Comitê Gestor da Internet no Brasil (Ed.). TIC domicílios e empresas 2011: Pesquisa sobre o uso das tecnologias de informação e comunicação no Brasil. São Paulo: Comitê Gestor da Internet no Brasil, 2012a.

BRASIL, Ministério da Educação e Instituto Nacional de Estudos e Pesquisas Educacionais Anísio Teixeira. Censo da educação básica: 2011 - resumo técnico. Brasília: MEC/Instituto Nacional de Estudos e Pesquisas Educacionais Anísio Teixeira, 2012b. Disponível em: http://download.inep.gov.br/educacao basica/censo escolar/resumos tecnicos/res umo tecnico censo educacao basica 2011.pdf. Acesso em 01/09/2013.

BRASIL. Alexandre F. Barbosa. Comitê Gestor da Internet no Brasil (Ed.). TIC domicílios e empresas 2012: Pesquisa sobre o uso das tecnologias de informação e comunicação no Brasil. São Paulo: Comitê Gestor da Internet no Brasil, 2013a.

BRASIL. Alexandre F. Barbosa. Comitê Gestor da Internet no Brasil (Ed.). TIC educação 2012: Pesquisa sobre 0 uso das tecnologias de informação e comunicação no Brasil. São Paulo: Comitê Gestor da Internet no Brasil, 2013b.

BRASIL. Guia de livros didáticos: PNLD 2014: matemática. - Brasília : Ministério da Educação, Secretaria de Educação Básica, 2013c. 
CASTRO FILHO, J.A. A porcentagem no contexto escolar: estratégias utilizadas pelos alunos. Temas em psicologia, Ribeirão Preto, v. 3, n. 1, abr. 1995 Disponível em <http://pepsic.bvsalud.org/scielo.php?script=sci_arttext\&pid=S1413389X1995000100005\&lng=pt\&nrm=iso >. acessos em 12 dez. 2014.

CRUZ, I. M.C. A. A WebQuest na sala de aula de Matemática : um estudo sobre a aprendizagem dos "Lugares Geométricos" por alunos do $8^{\circ}$ ano. 2006. Dissertação (Mestrado em Educação) - Instituto de Educação e Psicologia, Universidade do Minho, Braga. 2006.

DIAS, R. V. O Uso de porcentagem no cotidiano dos alunos. 2008. $120 \mathrm{f}$. Dissertação (Mestrado em Educação em Ciências e Matemática)- Faculdade de Física, PUCRS, Porto Alegre, 2008.

DINIZ, R.S. WebQuest: elo entre a matemática e a informática. In: Encontro Nacional de Educação Matemática, 2013, Curitiba. Anais do XI Encontro Nacional de Educação Matemática, 2013.

DODGE, Bernie. WebQuests: A Technique for Internet - Based Learning. The Distance Educator, Tradução de Jarbas Novelino Barato.V.1, no 2, 1995.

FIGUEIREDO, F. F. Resolução de problemas no ensino de porcentagem: em busca de uma compreensão pedagógica a partir de processos reguladores gerias da teoria de Robbie Case. 2008. Dissertação (Mestrado Profissionalizante em Ensino de Física e Matemática)- Centro Universitário Franciscano, Santa Maria, 2008.

FUNDAÇÃO GETÚLIO VARGAS. Centro de Tecnologia e Sociedade da Escola de Direito do Rio de Janeiro. Relatório de políticas de Internet : Brasil 2011. São Paulo: Comitê Gestor da Internet no Brasil, 2012. Disponível em: http://www.cgi.br/publicacoes/livros/pdf/relatorio-politicas-Internet-pt.pdf, acesso em 01/09/2013.

GIL, A.C. Didática do Ensino Superior. São Paulo: Atlas, 2006.

GONSALVES E.P. Conversas sobre a iniciação à pesquisa científica. Campinas: Editora Alínea, 2005.

GRANDO, R. C. O Jogo e suas Possibilidades Metodológicas no Processo Ensino Aprendizagem da Matemática. Campinas, SP,1995. 175p. Dissertação de Mestrado. Faculdade de Educação, UNICAMP.

LIMA, M.A.C.; CASSIANI, S.H.D.B. Pensamento crítico: um enfoque na educação de enfermagem. Rev.latinoam.enfermagem, Ribeirão Preto, v. 8, n. 1, p. 23-30, janeiro 2000.

MATHIAS, C. V. WebQuest: o que é e como fazer? In: Encontro Nacional de Educação Matemática, 2013, Curitiba. Anais do XI Encontro Nacional de Educação Matemática, 2013. 
MOREN, E.B.S.; ROCHA DOS SANTOS, A. Uma reflexão sobre ações de formação de professores no Brasil. Revista Ibero-americana de Educação, 55(1), pp. 1-13, 2001.

OLIVEIRA, A. C. et al. WebQuest: auxiliando na revisão de conteúdos. In: Encontro Nacional de Educação Matemática, 2013, Curitiba. Anais do XI Encontro Nacional de Educação Matemática, 2013.

PEREIRA, J. E. D.; ZEICHNER, K. M. (orgs.) A pesquisa na formação e no trabalho docente. Belo Horizonte: Autêntica, 2008.

RUGGIERO, M. A.; BASSO, I. S. A Matemática no Livro Didático: uma reflexão crítica na perspectiva histórico-cultural. BOLEMA, Rio Claro, SP, n. 20, ano 16, p. 17-36, 2003.

SANTOS, A. I. Recursos Educacionais Abertos no Brasil : [livro eletrônico] : o estado da arte, desafios e perspectivas para o desenvolvimento e inovação . São Paulo : Comitê Gestor da Internet no Brasil, 2013. Disponível em: $<$ http://www.cetic.br/publicacoes/2012/rea-andreia-inamorato.pdf $>$, acesso em 04/01/2013.

SÃO PAULO (Estado). Secretaria da Educação do Estado. Proposta Curricular do Estado de São Paulo: Matemática. Coord. Maria Inês Fini. São Paulo: SEE, 2008.

SILVA, D. J. R et al. WebQuest: Aprendendo matemática na Internet. In: Encontro Nacional de Educação Matemática, 2013, Curitiba. Anais do XI Encontro Nacional de Educação Matemática, 2013.

SILVA, K. X. S. WebQuest: Uma metodologia para pesquisa escolar com base na Internet. 2006. Dissertação (Mestrado em Educação) - Universidade Católica de Brasília, Brasília. 2006.

SILVA, M. M. Dificuldades de Alunos do Ensino Médio em Questões de Matemática do Ensino Fundamental. 2006. 100 f. Dissertação (Mestrado em Educação em Ciências e Matemática), Faculdade de Física., Pontifícia Universidade Católica do Rio Grande do Sul., Porto Alegre, 2006.

SMOLE, K.S. et al. Jogos de Matemática: de 1 a 3o ano - Porto Alegre: Artmed, 2008.

THIOLLENT, M. Metodologia da Pesquisa-ação. 15. ed. São Paulo: Cortez, 2007. (Coleção temas básicos de pesquisa-ação).

VIZOLLI, I. Registros de alunos e professores de educação de jovens e adultos na solução de problemas de proporção-porcentagem. 2006. 245 f. + 188 anexos (CD). Tese (Doutorado em Educação) - Universidade federal do Paraná, Curitiba, 2006. 